UNIVERSIDADE DE SÃO PAULO

FACULDADE DE FILOSOFIA, LETRAS E CIÊNCIAS HUMANAS

DEPARTAMENTO DE GEOGRAFIA

PROGRAMA DE PÓS-GRADUAÇÃO EM GEOGRAFIA FÍSICA

\title{
Anamorfose: um recurso cartográfico relevante na Geografia urbana do município de São Paulo.
}

Daniela Tobias

Versão Corrigida 
UNIVERSIDADE DE SÃO PAULO

FACULDADE DE FILOSOFIA, LETRAS E CIÊNCIAS HUMANAS

DEPARTAMENTO DE GEOGRAFIA

PROGRAMA DE PÓS-GRADUAÇÃO EM GEOGRAFIA FÍSICA

\section{Anamorfose: um recurso cartográfico relevante na Geografia urbana do município de São Paulo.}

Dissertação apresentada ao Programa de Pós-Graduação em Geografia Física, do Departamento de Geografia da Faculdade de Filosofia, Letras e Ciências Humanas da Universidade de São Paulo, para obtenção do título de Mestre em Geografia.

Mestranda: Daniela Cristina Tobias - no. USP: 6604088

Orientadora: Prof ${ }^{\mathrm{a}}$. Dra . Maria Elena Ramos Simielli - "de acordo":

Versão Corrigida

São Paulo

2011 
Para meus amores

Kajal, Nícolas, Nicole e Natália. 


\section{AGRADECIMENTOS}

A minha orientadora, $\operatorname{Prof}^{\mathrm{a}} \mathrm{Dr}^{\mathrm{a}}$ Maria Elena Ramos Simielli, por sua generosidade, orientação e disponibilidade.

Ao Prof. Dr. Alfredo Pereira de Queiroz Filho pela oportunidade de ingresso no programa de mestrado e orientações despendidas.

A Prof ${ }^{\mathrm{a}} \mathrm{Dr}^{\mathrm{a}}$ Fernanda Padovesi Fonseca, pela presença atuante em todo o processo de construção e condução dos meus caminhos pela Geografia, sua orientação, indicações de rumos, apoio e exemplo.

A Prof $^{a}$ Dr $^{\mathrm{a}}$ Gisele Girardi, por sua orientação, apreciação e valorosa discussão durante o processo de qualificação.

Aos amigos e mestres, Fernanda Padovesi Fonseca, Jaime Tadeu Oliva, José Pereira de Queiroz Neto, Eliane Kuvasney, Ricardo Mendes Antas Júnior, que contribuíram para a minha formação de geógrafa e estiveram presentes durante a aquisição de novos conhecimentos que se somavam as bases construídas por eles.

Aos amigos e pesquisadores, Eduardo Dutenkefer, Vania Alves Gonçalves Pupo, Ana Helena Grizotto e Michela Spina, pelas valorosas interlocuções e apoio em todo o percurso.

Aos amigos e profissionais da educação, Josete Santos, Paula Silva, Lucinalva de Souza, Marlene Dantas, Carlos Eduardo Capestrani, Raquel Lima, Vera Morota, Renato Prado e Lizeth Kyiama, pelo apoio constante e diálogos enriquecedores.

Aos meus familiares por perdoarem a minha ausência a diversos eventos.

Aos meus alunos, por contribuírem com a certeza de que valeria a pena. 


\section{SUMÁRIO}

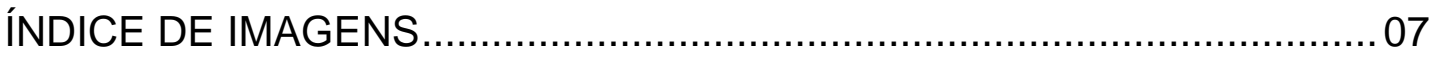

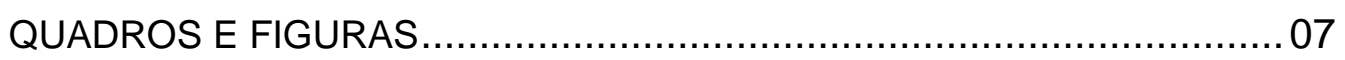

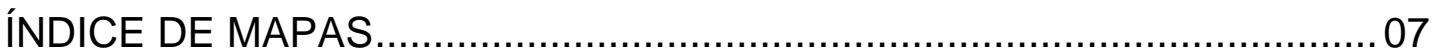

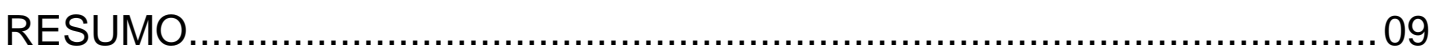

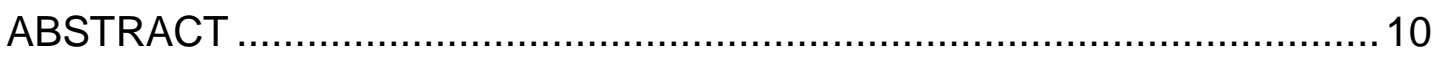

RÉSUMÉ

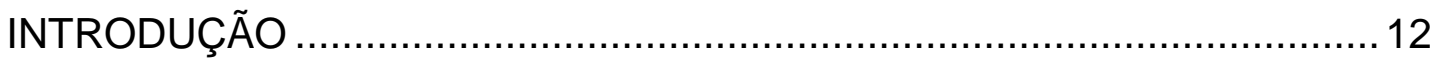

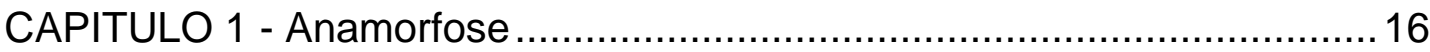

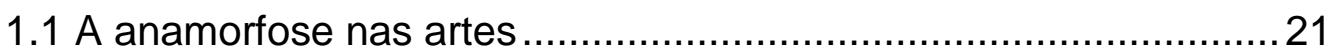

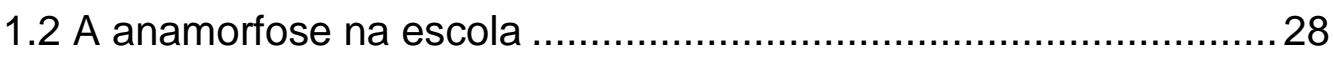

CAPITULO 2 - O espaço da cidade ............................................................ 31

CAPÍTULO 3 - Elementos de análise para a cidade de São Paulo

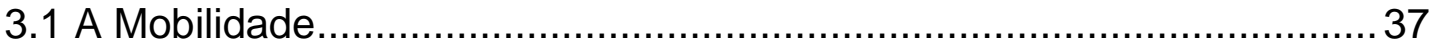

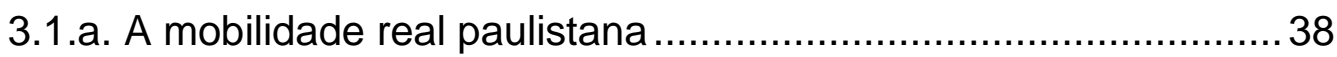

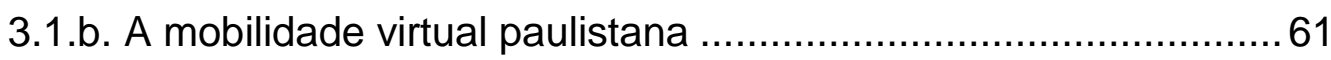

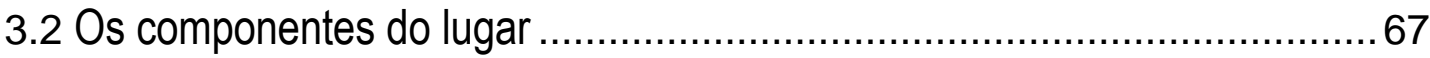

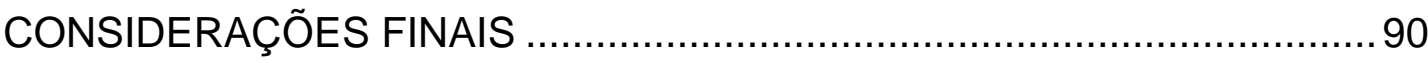

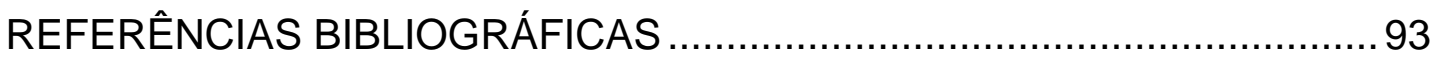




\section{ÍNDICE DE IMAGENS}

\section{QUADROS}

1 - Os elementos constituidores de uma cidade

FIGURAS

1 - "Les demoiselles d'Avignon" - Picasso ……………………….....23

2 - "Violon et Cruch" - Violino e jarro - Georges Braque .....................24

3 - "Os embaixadores"- de Hans Holbein .............................................25

4 - "Varanda" de Mauritus Cornelis Escher ……………...................27

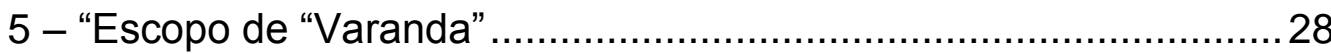

\section{ÍNDICE DE MAPAS}

1 - Com métrica topográfica - eleições presidenciais da Suiça ............17

2 - Mapa em anamorfose - eleições presidenciais da Suiça ................ 18

3 - "Apropriação desigual da internet" ............................................... 19

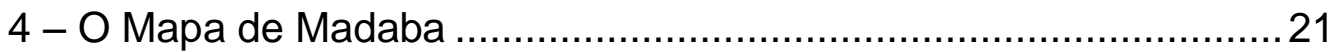

5 - Polígonos da Cidade de São Paulo ...............................................36

6 - Tempo médio para se chegar ao trabalho - São Paulo 2009 ........ 43

7 - Tempo médio para se chegar ao trabalho - Comparado................. 44

8 - Satisfação com a oferta de transportes coletivos............................ 45

9 - Comparativo entre os mapas de Satisfação com a oferta de transportes

coletivos e Tempo médio para se chegar ao trabalho - São Paulo 2009.................. 46

10 - Conservação de Ruas e Avenidas - São Paulo 2009 .................. 47

11 - Renda até 5 Salários Mínimos e Conservação de Ruas e Avenidas

- Comparação com um Fundo Populacional ............................................. 48

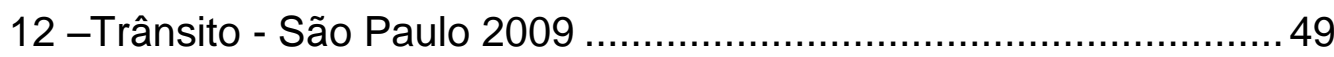


13 - Comparativo entre Trânsito e Conservação de Ruas e Avenidas 50

14 - Estabelecimentos Comerciais e de Serviços ................................55

15 - Shopping Centers - São Paulo 2008 ........................................56

16 - Salas de Cinema em Shopping Centers ....................................57

17 - Salas de Teatro, Shows e Concertos ..........................................58

18 - Salas de Teatro e Cinema nos CÉUS.........................................59

19 - Estabelecimentos Esportivos - públicos e privados ......................60

20 - Telefone Fixo por Distrito - São Paulo 2009.................................64

21 - Acesso a Internet por Distrito - São Paulo 2009 ...........................65

22 - TV por Assinatura - São Paulo 2009.......................................... 66

23 - Fornecimento de Água - São Paulo 2009 .....................................69

24 - Fornecimento de Energia Elétrica - São Paulo 2009 ....................70

25 - Esgoto - São Paulo 2009 ......................................................... 71

26 - Habitação e Moradia - São Paulo 2009 ......................................73

27 - Distribuição das Favelas - São Paulo 2007.................................74

28 - Enchentes - São Paulo 2009.................................................. 79

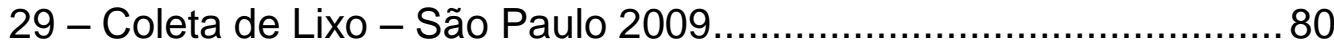

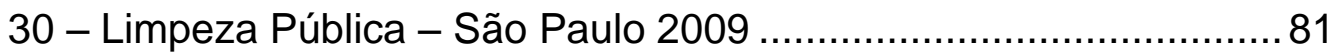

31 - Segurança Pública - São Paulo 2009 ........................................ 82

32 - Iluminação Pública - São Paulo 2009 .......................................... 83

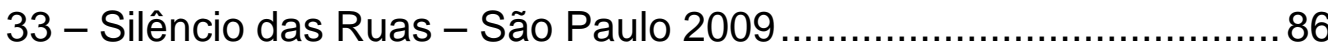

34 - Distribuição das Praças Públicas e Canteiros Centrais .................87

35 - Satisfação dos Moradores - São Paulo 2009 ............................... 89 


\section{RESUMO}

Nesta pesquisa, a anamorfose foi utilizada como um recurso cartográfico para representar dinâmicas espaciais do espaço urbano, que não se expressam adequadamente no espaço euclidiano, pois nesse nem todas as relações geradas nos espaços construídos são valorizadas. No caso, a anamorfose foi tomada como um instrumento capaz de evidenciar as múltiplas espacialidades sociais nas cidades e nos espaços urbanos, de um modo geral. Com esse recurso, o município de São Paulo foi objeto da geração de um conjunto de mapas que priorizam índices do cotidiano e apresentam as percepções da sociedade paulistana com o seu espaço vivido, tais como, as condições de mobilidade e sua satisfação ou insatisfação com os equipamentos urbanos ofertados nos distritos do município. A apresentação dos mapas anamórficos relaciona a distribuição geográfica da população do município e os índices de presença do poder público (e mesmo o privado), cujos resultados podem gerar maior e menor possibilidade de práticas sociais na cidade, condição necessária para a construção de uma cidadania com participação ativa no planejamento e na gestão da cidade, a partir do seu conhecimento e de sua identificação com este espaço.

Palavras-chave: anamorfose, cidade, São Paulo, urbano, mobilidade, mapas, equipamentos urbanos. 


\section{ABSTRACT}

The anamorphosis has been used in this research as a cartographic tool indicated to represent the geographic phenomena within the urban spaces, which distance the Euclidean spatial relations and add value to existing socially constructed spaces. A tool that is able to remark the multiple spatialities in urban environments and in the city. As well as the dynamics of human actions within this space; this is possible through generated maps, which prioritize daily rates and present the relations of perception of the society towards its lived space, its mobility conditions and its satisfaction or dissatisfaction with urban facilities offered in the districts of the city. The presentation of the anamorphic maps that relate the distribution of city population and the proportion of the presence of the public and even private power, generating higher and lower possibility of the city practice and the possibility of creating a urban citizen, participative in the urban planning and city management, from their knowledge and their identification with this space.

Keywords: anamorphosis, city, Sao Paulo, urban, mobility, maps, urban facilities. 


\section{RÉSUMÉ}

L'anamorphose a été utilisée dans cette recherche comme l'outil cartographique pour représenter les phénomènes géographiques, dans les espaces urbaines, qui éloignent les relations spatiales euclidiennes et valorisent les espaces existants socialement construits. Un outil capable d'évidencier les multiples spatialités aux ambients urbains et en ville. Ainsi comme la dynamique des actions humaines dans cet espace; cela est possible grâce à des cartes créées, qui donnent la priorité aux indices quotidiens et présentent les rélations de perception de la société de l'espace vecu, ses conditions de mobilité e sa satisfaction ou insatisfaction avec les équipements urbains oferts dans les districts de la ville. La présentation des cartes anamorphiques qui lient la distribution de la population de la ville et la proportion de la présence du pouvoir publique ou même privé, créant des possibilités supérieures ou inférieures de la pratique de la ville et de la possibilité de construction d'un citoyen urbain participatif à la planification et gestion urbaine, à partir de ses connaissances e de son identification avec cet espace.

Mots-clés: anamorphose, ville, São Paulo, mobilité, cartes, équipements urbains. 


\section{INTRODUÇÃO}

A cidade de São Paulo, que apresenta hoje uma hegemonia econômica, técnica e mesmo científica sobre as demais cidades brasileiras, é classificada como "centro de gravidade econômica" (THÉRY, MELLO; 2005,p.43), como "metrópole informacional", "metrópole onipresente" (SANTOS, 2005, p.103). Tomou forma no decorrer da evolução dos meios geográficos ${ }^{1}$ em virtude da estrutura industrial que possibilitou as transições necessárias para que esta cidade se tornasse um polo das relações nacionais com as demais realidades mundiais.

São Paulo é hoje mais do que uma cidade industrial. São outras características que lhe garantem a superioridade produtiva.

"Ainda que, se compararmos com o resto do país, o peso
da atividade industrial seja muito expressivo na
aglomeração paulistana, não é essa função metropolitana
que atualmente assegura a São Paulo papel diretor na
dinâmica espacial brasileira. Esse papel é, por causa de
suas atividades quaternárias de criação e controle,
praticamente sem competidor no país, pois agora são os
fluxos de informação que hierarquizam o sistema urbano.
O papel de comando é devido a essas formas superiores
de produção não material, elas próprias sendo
consequência da integração crescente do país às novas
condições da vida internacional" (SANTOS, 2005, p. 103)

O espaço urbano que se fundamenta, entre outros elementos, nas lógicas de mercado e no caso específico, para São Paulo, também, nas lógicas do mercado internacional, por tratar-se de uma cidade que está inserida neste processo mundial de redes e contatos, faz com que esse espaço exerça forte influência no modo de vida do citadino. O citadino que também é levado a vivenciar essa internacionalização mercantil e visualizar, muitas vezes, uma contradição, entre a grandeza das relações do mercado internacional e a realidade social apresentada, verificando que "parcelas cada vez maiores da

\footnotetext{
${ }^{1}$ Forma de periodização apresentada por SANTOS e SILVEIR|A in: O Brasil - Território e Sociedade no início do séc. XXI, 2005, p.27, onde afirmam: “... ao longo da história da organização do território brasileiro, três grandes momentos poderiam, grosso modo, ser identificados: os meios "naturais", os meios técnicos e os meios técnico-científico-informacional. Por meio de suas técnicas diversas no tempo e nos lugares, a sociedade foi construindo uma história dos usos do território nacional".
} 
receita pública se dirigem à cidade econômica em detrimento da cidade social" (SANTOS, 2005, p.107). Isso gera, na cidade, um arranjo próprio desse período Técnico, Científico e Informacional, revelando uma cidade que está dissociada de um espaço físico absoluto e que alcança dimensões sociais de distribuição e organização.

Raquel Rolnik (1995, p.63) chama a atenção ao fato de que "o próprio espaço urbano é uma mercadoria" o que também nos obriga a elevar a análise para além da forma desse espaço, e verificar como se organiza o espaço urbano, sabendo que esse espaço possui um mercado volátil e metamórfico.

A organização espacial paulistana tem o poder de agir diretamente no modo de vida interno da cidade e, através da existência de um "Tempo único", de uma "Técnica única" e movida pelo mesmo "Motor" (SANTOS, 2006, p. 2430), influencia também os espaços mais afastados dentro do Território nacional, chegando a ultrapassar as fronteiras nacionais em determinados nichos urbanos, econômicos, culturais e sociais.

$\mathrm{Na}$ visão dos pós-modernistas a cidade não depende apenas das relações que ela estabelece com o seu entorno metropolitano e mesmo internacional. Analisam as suas formas e reformas, referindo-se à cidade, a partir de seus próprios arranjos internos.

"A aparência de uma cidade e o modo como os seus espaços se organizam formam uma base material a partir da qual é possível pensar, avaliar e realizar uma gama de possíveis sensações e práticas sociais."

(HARVEY, 1992, p.69)

Edward Soja (1993, p.158) nos coloca a importância da relação social com o espaço, para que este venha a existir. "A estruturação espaço temporal da vida social define o modo como a ação e a relação sociais (inclusive as relações de classe) são materialmente constituídas, concretizadas".

David Harvey, ao citar Roland Barthes (1993, p.69), afirma que, “... a cidade é um discurso e esse discurso é na verdade uma linguagem, então temos que dar estreita atenção ao que está sendo dito, em particular porque é típico absorvermos essas mensagens em meio a todas as outras distrações da vida urbana." 
Doreen Massey nos relata que embora possa haver padrões de análise para o espacial/urbano a realidade de cada lugar é preservada pela forma como a sociedade interage com este espaço.

"Se se reconhece que as pessoas têm identidades múltiplas, pode-se dizer a mesma coisa dos lugares. Ademais essas identidades múltiplas podem ser uma fonte de riqueza ou de conflito, ou de ambas." (MASSEY, 2000, p.183).

Tomando a cidade, com os seus arranjos próprios e particulares, e com o objetivo de desenvolver uma análise espacial geográfica da cidade de São Paulo, decidimos seguir um rumo que nos desse a oportunidade de aprofundamento sobre alguns aspectos sociais. "A análise geográfica do mundo é aquela que caminha no desvendamento dos processos constitutivos do espaço social." - "A análise do processo de produção do espaço urbano requer a justaposição de vários níveis de realidade, momentos diferenciados da reprodução geral da sociedade." (CARLOS, 2001, p.12).

A cartografia é o meio escolhido para a busca da tradução deste discurso oferecido pela cidade, conforme disse Harvey (1993, p. 69) “... a cidade é um discurso e esse discurso é na verdade uma linguagem..." para uma verificação do que está posto e uma análise de seus resultados.

Há estudos que relatam um uso mais diverso e produtivo do mapa para a Geografia, com o uso da variação das métricas. Discussões são feitas sobre o papel de representações que não estejam em uma "prisão" ${ }^{2}$ gerada pelas convenções cartográficas, em um fundo de mapa euclidiano ${ }^{3}$. Muita das produções e discussões se referem às formas de representações cartográficas que consigam melhor trabalhar com as dimensões do urbano.

Neste eixo cartográfico - não euclidiano - apresentamos a anamorfose, como uma representação espacial que pode dar conta das realidades espaciais urbanas da cidade, um recurso cartográfico usado pela Geografia para

\footnotetext{
${ }^{2}$ Fonseca, F. utiliza o termo "prisão" referindo-se a falta de liberdade existente na cartografia tradicional em trabalhar com uma diversidade de linguagens, para representação nos mapas. em: A Inflexibilidade do Espaço Cartográfico - Uma questão para a geografia: Análise das discussões sobre o papel da cartografia. 2004.

${ }^{3}$ Fundo de mapa euclidiano - é aquele que utiliza a distância apresentada pela geometria euclidiana e preservam a orientação, tamanho e forma das figuras, medidas em segmentos matemáticos de referências retas e circulares.
} 
evidenciar os fenômenos estudados em detrimento das bases fixas do espaço absoluto, que é este espaço apresentado como sendo aprisionado pelas métricas euclidianas.

Em nossa dissertação buscaremos compreender melhor esse recurso cartográfico "anamorfose", que consideramos ser uma linguagem significativa da Geografia que pretendemos desenvolver.

Uma pesquisa feita pelo Datafolha e apresentada no jornal Folha de $\mathrm{S}$. Paulo em 2008 serviu de fonte de dados para confecção de mapas para esta dissertação. É um estudo que buscou cobrir o perfil, os hábitos e a percepção dos moradores dos distritos de São Paulo. A pesquisa levou o nome de DNA Paulistano, onde foram entrevistadas 28.389 pessoas com 16 anos ou mais, amostra que corresponde a $0,26 \%$ da população adulta da cidade ${ }^{4}$.

Outras fontes pesquisadas e utilizadas foram: INFOLOCAL (Sistema desenvolvido pela Secretaria Municipal de Planejamento - SEMPLA - São Paulo) e o IBGE (Instituto Brasileiro de Geografia e Estatística).

É fato que analisar a cidade de São Paulo é um desafio de grandes proporções.

Pretendemos, desta forma, com essa dissertação, contribuir com algumas análises cartográficas que venham a somar uma visão prospectiva e relativa do espaço da cidade de São Paulo.

\footnotetext{
${ }^{4}$ A pesquisa foi feita por 65 pesquisadores de campo na coleta dos dados.
} 


\title{
CAPÍTULO 1 - Anamorfose
}

Waldo Tobler apresenta seu método para construção de anamorfose cartográfica, desenvolvido nos anos 1960 se reportar à representação desenvolvida por Raisz ${ }^{5}$ nos anos 1930 como um diagrama cartográfico. Inicia, assim, a discussão sobre os usos da anamorfose.

\begin{abstract}
"São transformações cartográficas espaciais usadas para quebrar a ligação entre regiões, estatísticas e suas áreas topográficas. Consequentemente, isto libera uma variável visual (tamanho do polígono) para um uso mais relevante, tal como a representação da importância social relativa destas regiões (medidas geralmente pelo tamanho de suas populações)". (TOBLER, 2004, p. 59)
\end{abstract}

Quebrar essa relação significa quebrar a relação com o espaço apreendido pela geometria euclidiana. Isso significa que o espaço pode ser apreendido por outras formas, por novas relações. A visualização de novas apreensões espaciais nos ofereceram espaços não familiares.

\begin{abstract}
"Anamorfose vem do grego anamórphosis - transformação imagem disforme. Em francês, "anamorphose" [anamorfose]; em inglês: Cartogram [cartograma], "variable scale maps" [mapas com escala varáveis] ou "value-by-area" cartograms [cartogramas de valores de áreas] e em alemão: "verzerrte Karte" [carta distorcida, disforme]" (TOBLER, apud DUTENKEFER, 2010,p.78).
\end{abstract}

Waldo Tobler considera que é necessário ser sempre aberto às novidades e testá-las, porque permitem frequentemente renovar a disciplina e assim apreender a uma melhor compreensão dos fenômenos geográficos.

Colette Cauvin trata a construção cartográfica anamorfose como uma transformação cartográfica espacial que privilegia a transformação espacial livre de seus localizantes. Define da seguinte forma o conceito de anamorfose:

"A transformação cartográfica espacial é a passagem, graças a uma operação matemática (ou eventualmente gráfica), de uma forma do mapa a outra forma do mesmo espaço, privilegiando

\footnotetext{
${ }^{5}$ TOBLER, W. in Thirty Five Years of Computer Cartograms, Annals of the Association American, 2004
} 
a mudança dos localizantes espaciais. Desde que estas modificações originem deformações dos contornos, fala-se em anamorfose". (CAUVIN, 1995:270)

Nas páginas iniciais do aplicativo Scape $\mathrm{Toad}^{6}$, encontramos um exemplo de uso de anamorfose que segue as características apresentadas por Tobler e Cauvin e que estão colocadas com as seguintes definições:

"A visualização dos fenômenos sociais através da cartografia temática clássica leva muitas vezes a representações insatisfatórias... Anamorfose é uma técnica bem conhecida usada para compensar este inconveniente, quebrando o elo entre as regiões de estatística e suas áreas topográficas. Consequentemente, esta liberta uma variável visual (tamanho do polígono) para uma utilização mais relevante, tais como a representação da importância relativa social destas regiões (geralmente medidas pelo tamanho de suas populações), deixando intactas as suas relações topológicas. Imagine que você quer saber a opinião da população suíça sobre algum assunto da sociedade, então você apresenta um mapa eleitoral com duas variáveis "sim ou não" (vermelho para "não" e verde para "sim"). Se você usar métricas topográficas, você terá como resultado o mapa abaixo. Visualmente, a resposta "não" torna-se pequena, apenas residual". (Tradução nossa), acesso em21/03/2011 e disponível em: 〈http://scapetoad.choros.ch/help/v11>.

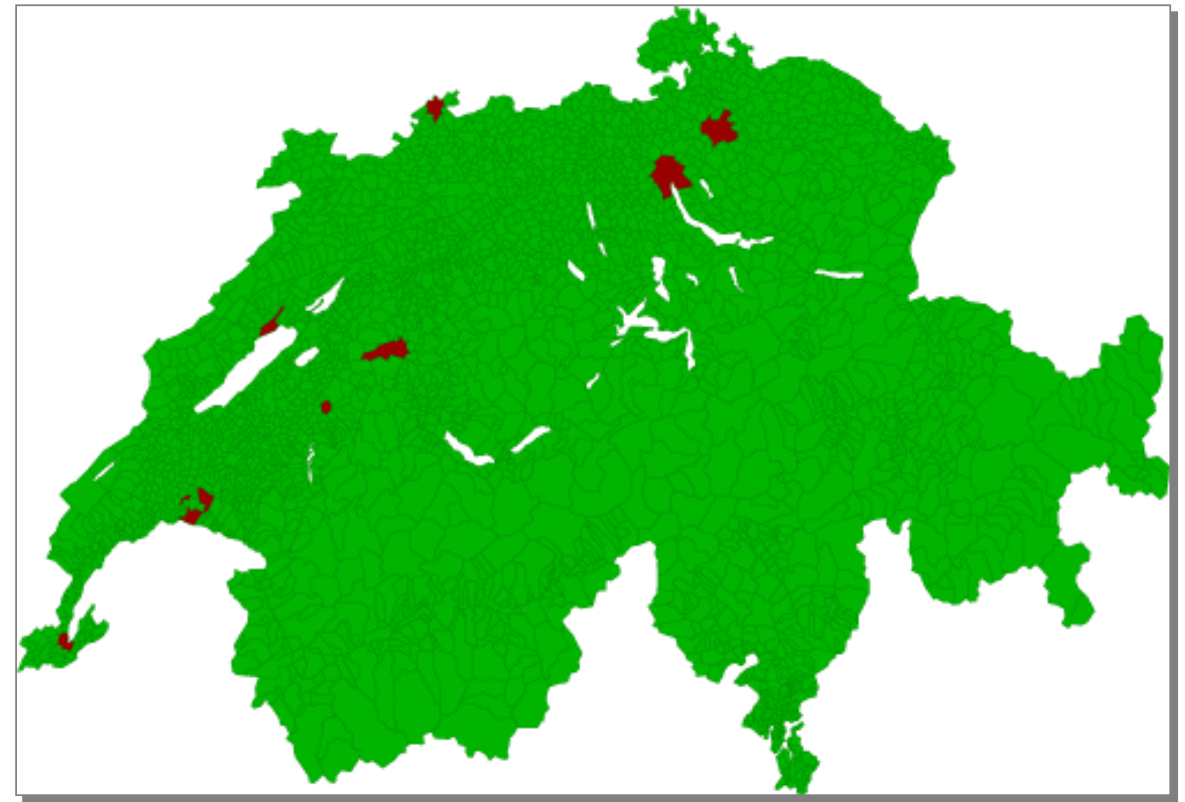

Mapa 1. Com métrica topográfica - eleições presidenciais da Suiça

\footnotetext{
${ }^{6}$ Scape Toad é um aplicativo de produção de anamorfoses, de uso livre e está disponível para download em: http://scapetoad.choros.ch/help/v11/. O aplicativo foi desenvolvido por: Dominique Andrieu (Maison des Sciences de l'Homme, Université François-Rabelais, Tours): conceituação, testes, documentação. Christian Kaiser (361DEGRES, Lausanne): conceituação, aplicação Java. André Ourednik (Chôros Laboratory, EPFL-ENAC-INTER): coordenação de produção e supervisão, a conceituação, documentação, logotipo, website.
} 
"Agora, se adaptarmos as superfícies com o tamanho da população. Essa adaptação levará a uma estimativa mais correta da proporção real de "sim" e "não", e sua resposta visual será": (Tradução nossa), acesso em 21/03/2011 e disponível em: <http://scapetoad.choros.ch/help/v11>.

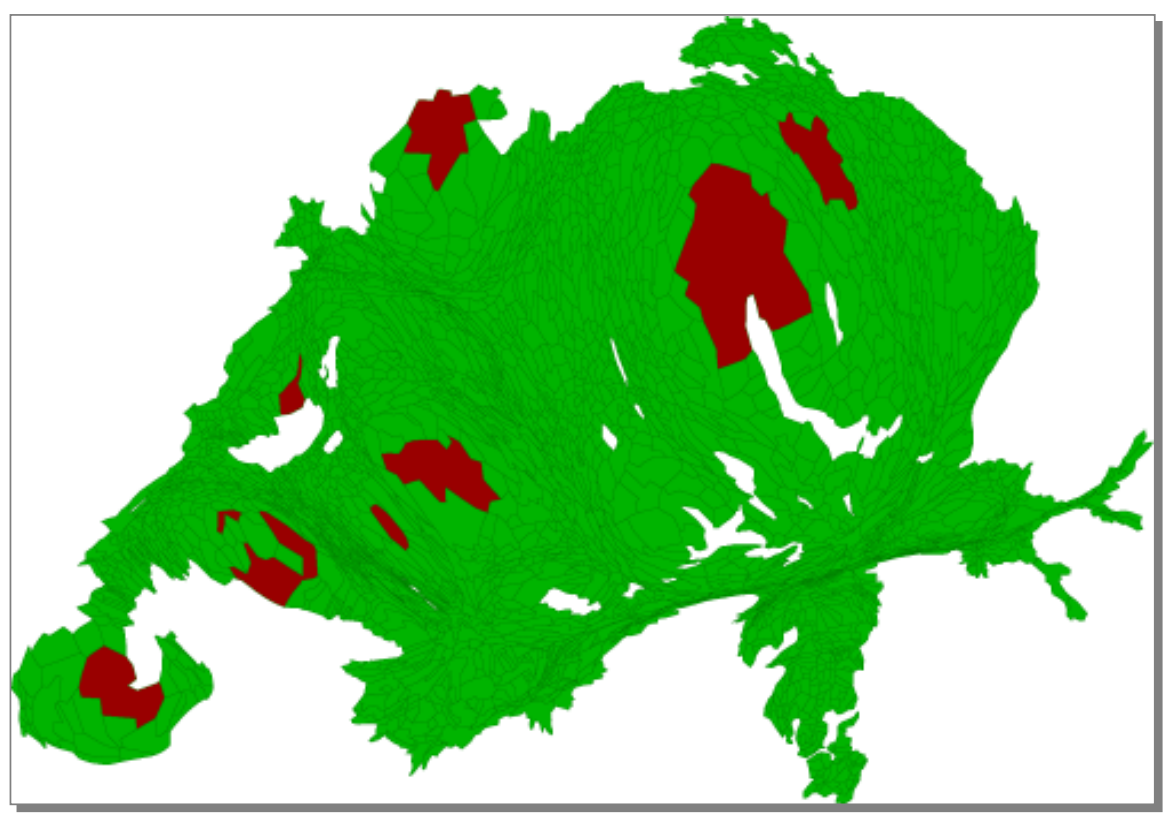

Mapa 2 - mapa em anamorfose - eleições presidenciais da Suiça

O site não disponibiliza os dados geradores do mapa, nem o ano de tais eleições. - sendo usado apenas como exemplo técnico).

Nesta mesma linha de construção de mapas encontramos uma série de produções realizadas por Jacques Lévy que desenvolveu uma obra coletiva "L'Invention Du Monde - Une géographie de la mondialisation - 2008" onde apresenta diversos mapas construídos em anamorfose e com recursos visuais de grande interesse para a cartografia. Há o objetivo claro por parte desse autor de ampliar esta forma de apresentação de mapa com novas possibilidades de construção. Novas tecnologias desenvolvidas para produção de mapas a serviço da Geografia, como é o caso do mapa de "Apropriação desigual da internet." (tradução nossa) mapa 3. 
Carte 3

L'inégale appropriation d'Internet
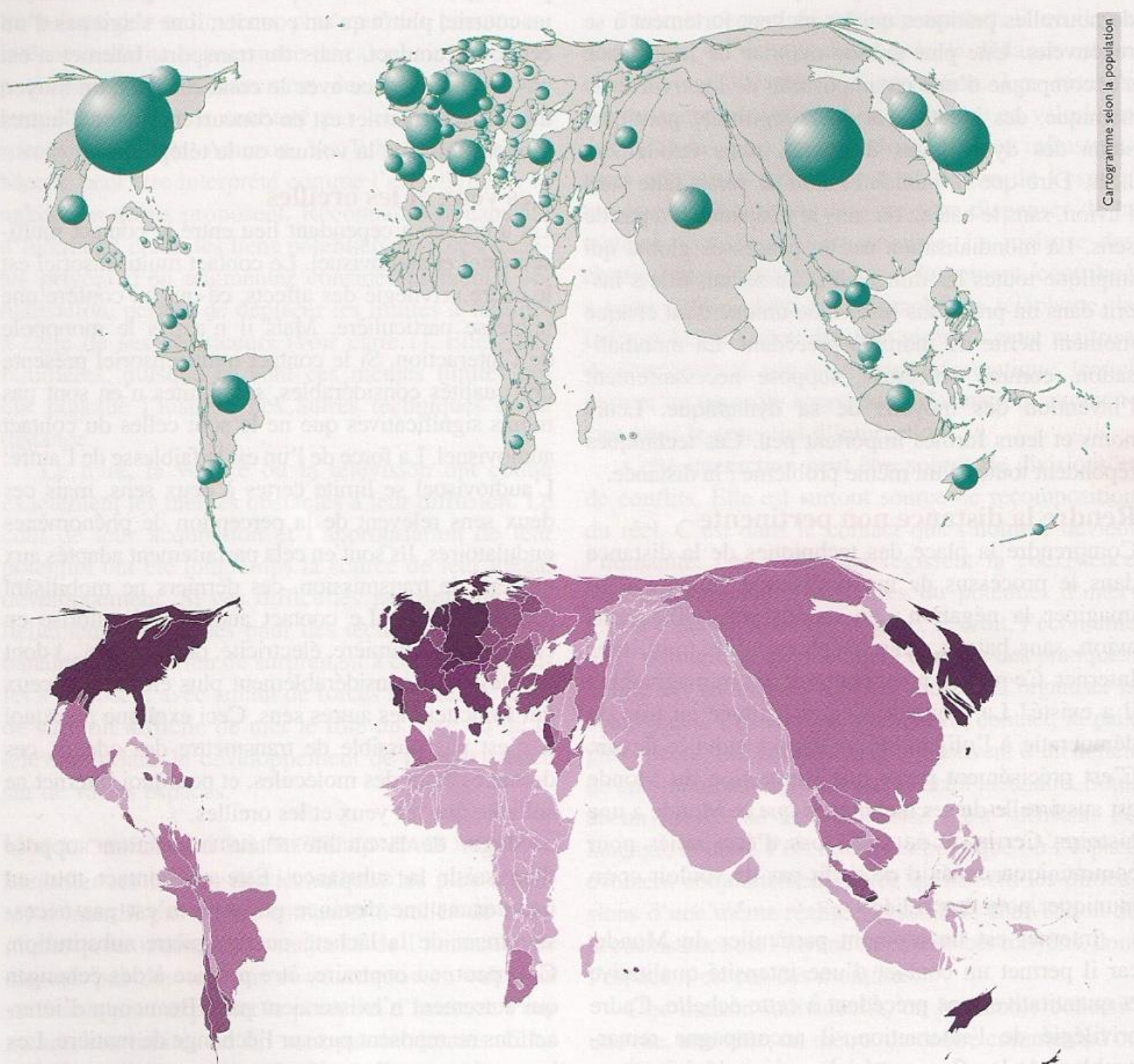

Nombre d'usagers d'Internet

par État en 2006 (exprimé en millions)

Taux de pénétration d'Internet en 2006

(exprimé en pourcentage de la population des États)

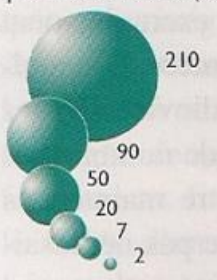

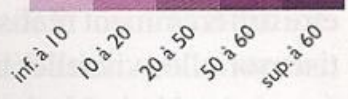

Mapa 3 - "Apropriação desigual da internet." (tradução nossa).

L'Invention Du Monde - Jacques Lévy (org.) - 2008, p.124 
Neste mapa vemos o uso da anamorfose com a métrica tamanho da população gerando as distorções nos contornos espaciais dos países, e ainda, o uso do valor da cor e do tamanho, para representar a "taxa de penetração da internet - 2006 - expressa em porcentagem da população dos países" e "Número de usuários da internet em 2006 - expresso em milhões", respectivamente.

Jacques Lévy (2003, p.74) conceitua anamorfose como sendo: "Procedimento que permite dar a um mapa ou mais precisamente, ao fundo de mapa uma métrica diferente da euclidiana". Para ilustrar seus argumentos 0 autor nos apresenta o mapa de Madaba (mapa 4)- um mosaico do séc $V$, como uma representação que utiliza a distância relativa entre os objetos, sendo assim uma anamorfose $\left(2008\right.$, p.165) ${ }^{7}$. Ao desconstruir seus componentes e buscar, qual a necessidade existente para representar este espaço e, dessa forma como ele é apresentado, vê-se sua intencionalidade específica. O mapa possui hipérboles em determinadas áreas e reduz a importância visual de outras. A escolha de uma representação multiescalar, como é o caso deste mapa, não pode simplesmente ser atribuída ao acaso. Essa prática atendeu a uma necessidade de comunicação existente neste período, onde são utilizadas as técnicas disponíveis para sua construção.

A anamorfose não é apresentada apenas para inovar as técnicas de construção cartográfica, embora também faça isso. E, vem para atender a uma necessidade atual de representação espacial.

\footnotetext{
${ }^{7}$ Gilles Palsky apresenta uma visão diferente sobre esta análise de Jácques Levy sobre o mapa de Madaba. Afirma que se trata de uma comparação anacrônica ao usar o termo anamorfose para um mapa histórico. Disponível em: http://www.persee.fr/web/revues/home/prescript/article/geo acesso em: 19/06/2011. (Tradução nossa)
} 


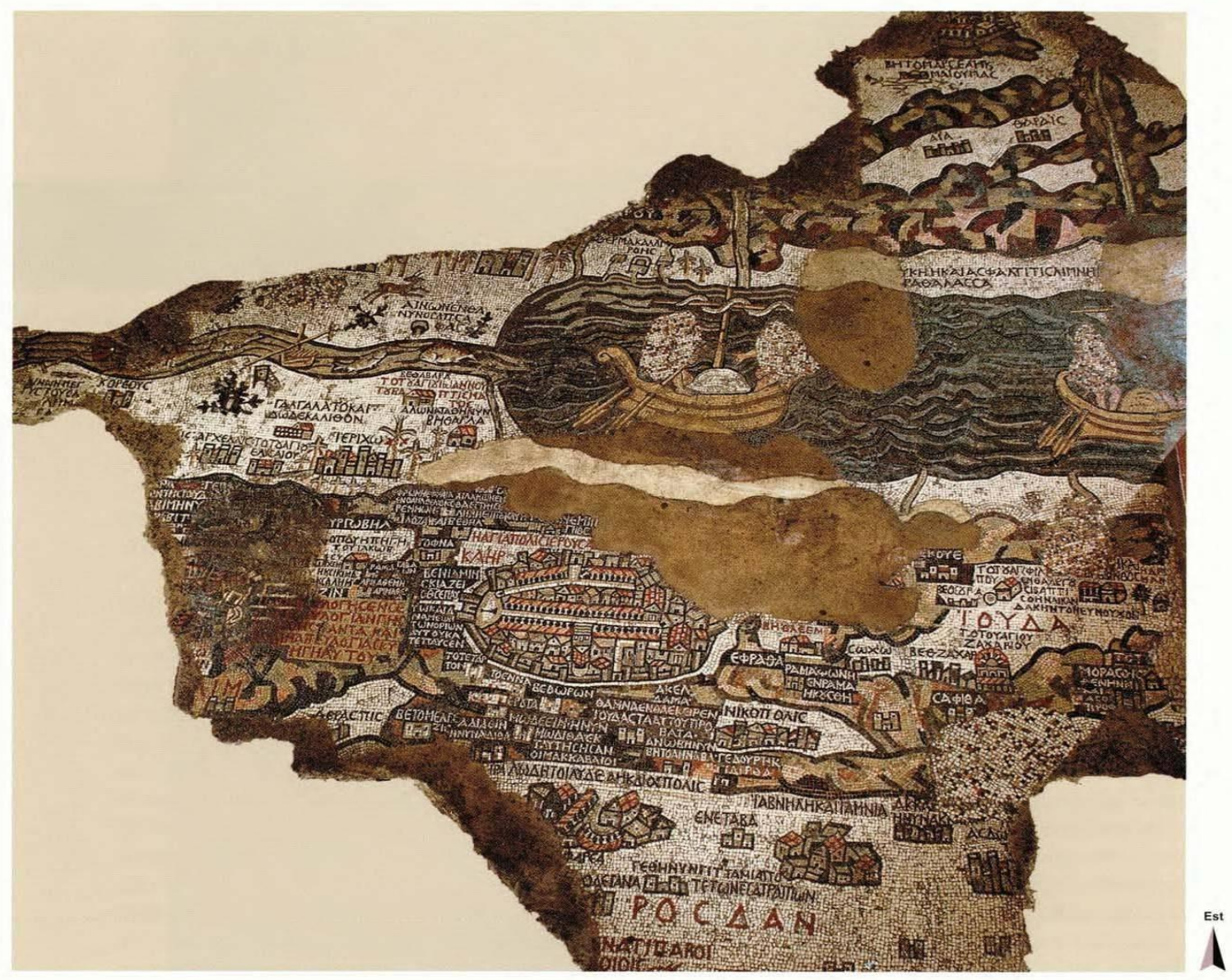

Mapa 4 - O mapa de Madaba 565 d.C.- mosaico de $25 \mathrm{~m}^{2}$ encontrado na Igreja Grega Ortodoxa de S. Jorge em Madaba ,Jordânia.

Disponível em: < http://www.geocities.ws/paz_israel/isrpais.htm> acesso em: 12/12/2010

Roger Brunet e Hervé Théry (PANIZZA, 2010) conceituam anamorfose de uma maneira bastante simplificada, como sendo: "a transformação de um contorno segundo um princípio definido".

Podemos encontrar os conceitos de anamorfose, muitas vezes, como uma crítica à sua forma, outras diretamente relacionadas aos conceitos artísticos ou matemáticos, onde são muito bem aceitos.

\subsection{A anamorfose nas Artes}

A anamorfose nas artes foi grande e efetivamente utilizada, através do cubismo, quando a percepção humanística se tornava expressiva e valorizada, não de forma totalitária quanto às anamorfoses, pois alguns as chamavam de 
distorções da arte, deformações e confusões visuais e outros adjetivos ligados ao desconforto visual.

É importante salientar que esse movimento de representação, com aparente distorção da forma espacial, não ganhou força por acaso - mas por estar intimamente ligado as descobertas científicas do século 19.

Com a apresentação da teoria da relatividade de Einstein ${ }^{8}$ e logo após a apresentação da teoria da indissociabilidade espaço-tempo de Minkowski ${ }^{9}$, a "quarta dimensão" ou a teoria "espaço-tempo quadridimensional" vai dar origem a trabalhos artísticos e científicos que buscarão abrir mão do espaço euclidiano como forma de representação espacial - o espaço euclidiano, pensado e trabalhado através da geometria euclidiana desenvolvida no século 3 a.C. por Euclides de Alexandria (360 a. C. - 295 a.C.) já não mais encontra espaço entre os novos conceitos trazidos pela geometria não-euclidiana, "teoria reformulada pelos cientistas: Georg F. Bernhard Riemann (1826-1866), Nikola I. Lobatchevski (1792-1856)". (Silva 2009, p.43)

Esta contribuição científica trará uma mudança radical nas expressões artísticas do início do século 20.

"Hoje os cientistas não se atêm às três dimensões da
geometria euclidiana. Os pintores foram levados muito
naturalmente, por intuição, a se preocuparem com as novas
medidas da extensão que, na linguagem dos ateliês modernos,
designávamos em conjunto e sumariamente com o termo
quarta dimensão". (APOLLINAIRE apud SILVA 2009, p.43)

Entre os artistas que se destacaram, por trabalharem de imediato com esta nova perspectiva espacial, encontramos o espanhol Pablo Picasso (18811973) e o francês Georges Braque (1882-1963) conhecidos posteriormente como os "pais do cubismo". Os artistas dessa época afirmaram que:

"Os novos episódios no progresso da humanidade somente podiam gerar constância criando novas formas de expressão". (APOLLINAIRE apud SILVA 2009, p 43).

\footnotetext{
${ }^{8}$ Albert Einstein - físico alemão (1879-1955)-desenvolveu a teoria da relatividade.

${ }^{9}$ Hermann Minkowski - matemático lituano (1864-1909), professor de Einstein na Suíça.
} 


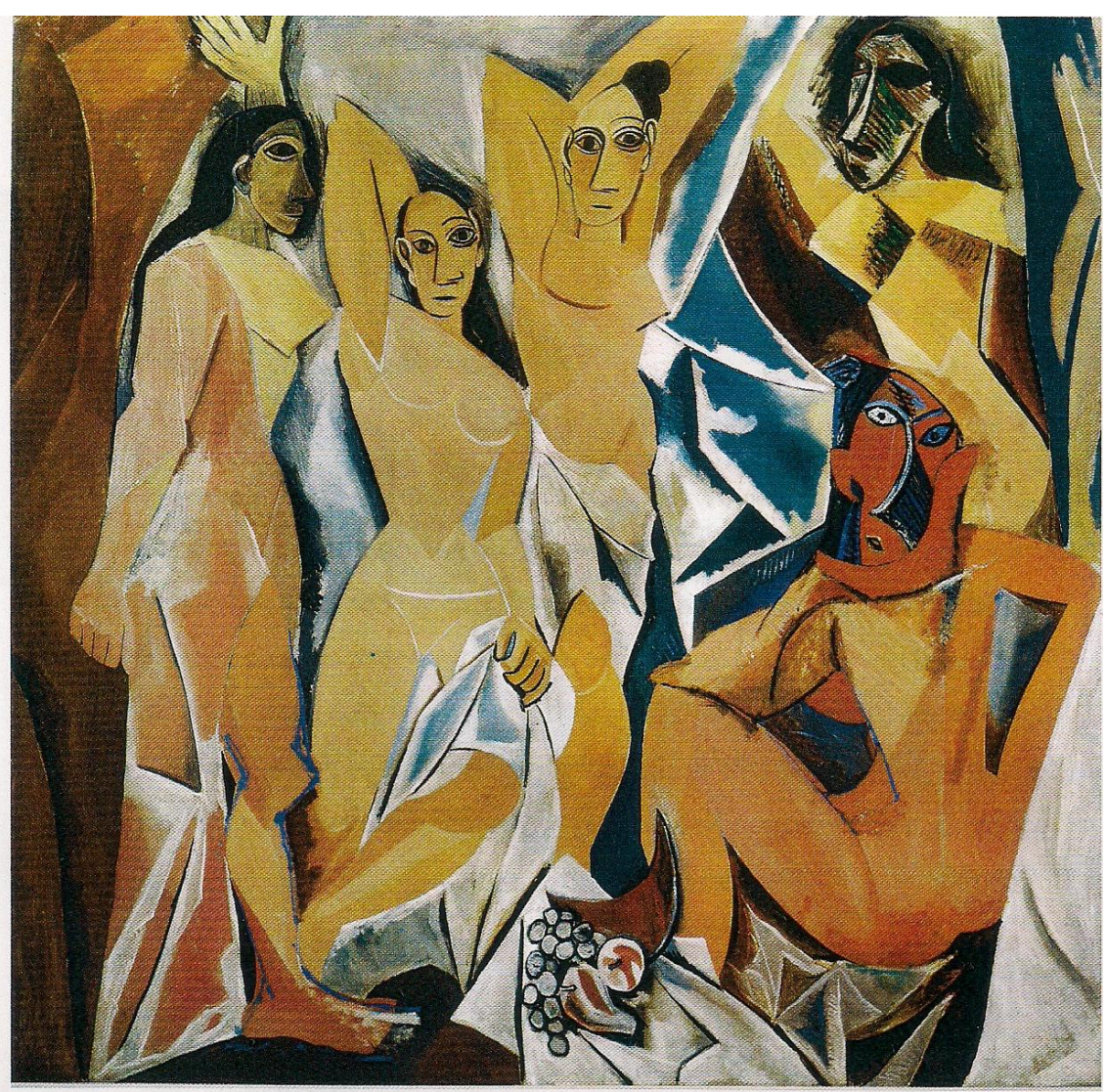

Figura 1. Les demoiselles d'Avignon - Picasso 1907 - pintura em óleo com $243.9 \mathrm{~cm} \times$ $233.7 \mathrm{~cm}$. Localização Museu de Arte Moderna, Nova lorque

Disponível em:< http://www.artchive.com/artchive/P/picasso/davignon.jpg.html> acesso em: 10/12/2010

No quadro de Picasso, (Figura 1) considerado o primeiro do movimento cubista, temos a presença da representação da quadridimensionalidade, através das formas das mulheres e principalmente da figura da mulher sentada, como apresentada na seguinte análise.

\begin{abstract}
"Observando atentamente essa figura, nota-se que está representada de costas, com as pernas abertas e paralelas ao plano da tela, mas sua face está voltada para o espectador, ou seja, formando um ângulo de 180 graus em relação à posição das pernas. Além disso, sob o seu braço esquerdo, que está apoiado no joelho, vê-se parte de um dos seios, indicando que o tórax está representado em outro ângulo, diferente da posição das pernas e do rosto". (SILVA, 2009,p. 43)
\end{abstract}

Georges Braque buscou ir além, lançando mão do conceito de múltiplas dimensões, bastante estudado neste período representado em sua pintura Violino e Jarro (Figura 2). 


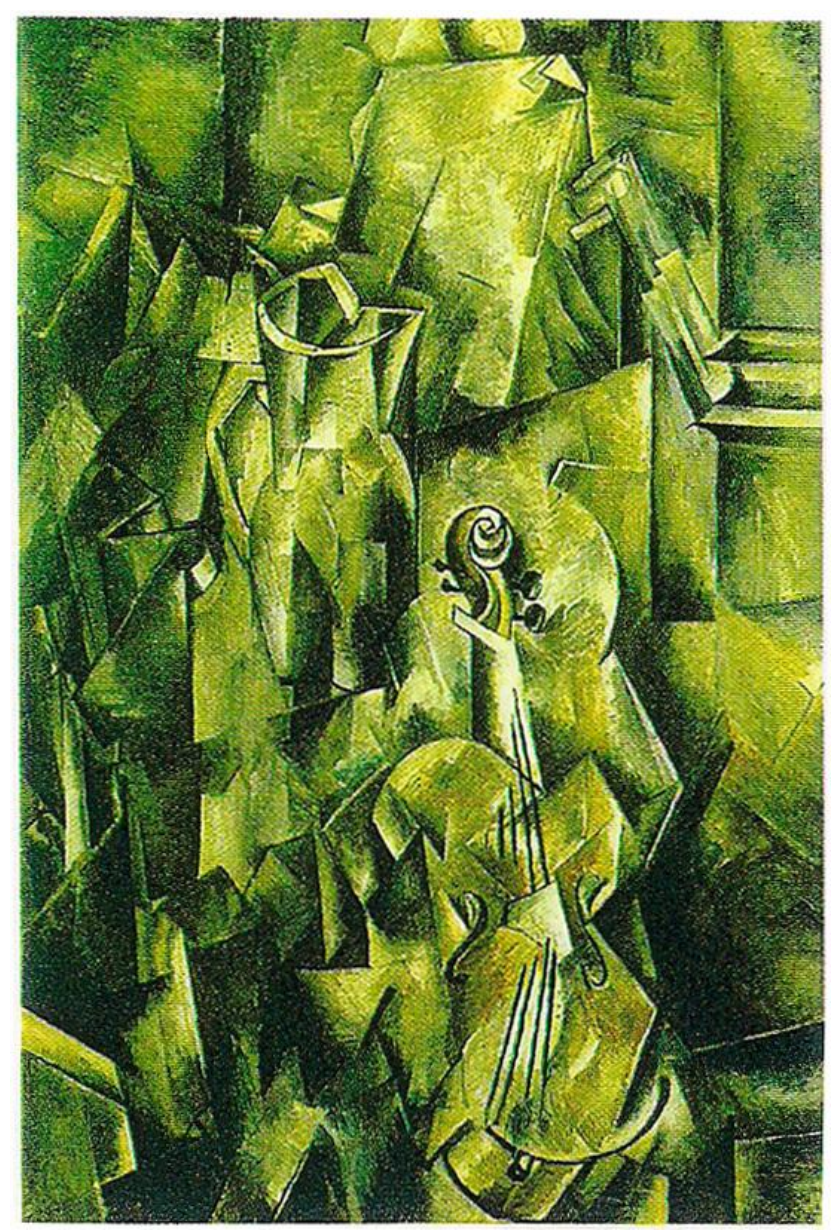

Figura 2. Violon et Cruch - Violino e jarro - Georges Braque 1909-1910

Disponível em: http://artnowjk.wordpress.com/2010/05/03/cubismo/ acesso em: 10/12/2010.

José Marcus Romão da Silva ${ }^{10}$ realiza análise sobre a obra de Braque:

[...] "nessa obra o objeto e o espaço estão em total interdependência, a tal ponto que é praticamente impossível distinguir os limites entre ambos. Conforme observa o físicoteórico norte-americano Lee Smolin, "o espaço não é algo separado das coisas que existem - é apenas um aspecto das relações que existem entre elas". Ora é exatamente esse tipo de associação relacional que a obra de Braque é capaz de suscitar, pois tanto o objeto como o espaço são desdobrados em uma miríade de planos e volumes que compõem um jogo inextricável de múltiplas relações". (SILVA, 2009, p.44)

${ }^{10}$ SILVA, J. - Publicou o artigo: O cubismo e a teoria da relatividade na revista Ciência hoje, outubro de 2009 - o autor pertence ao Departamento de Artes e Representação Gráfica - da Universidade Estadual Paulista (campus Bauru). 


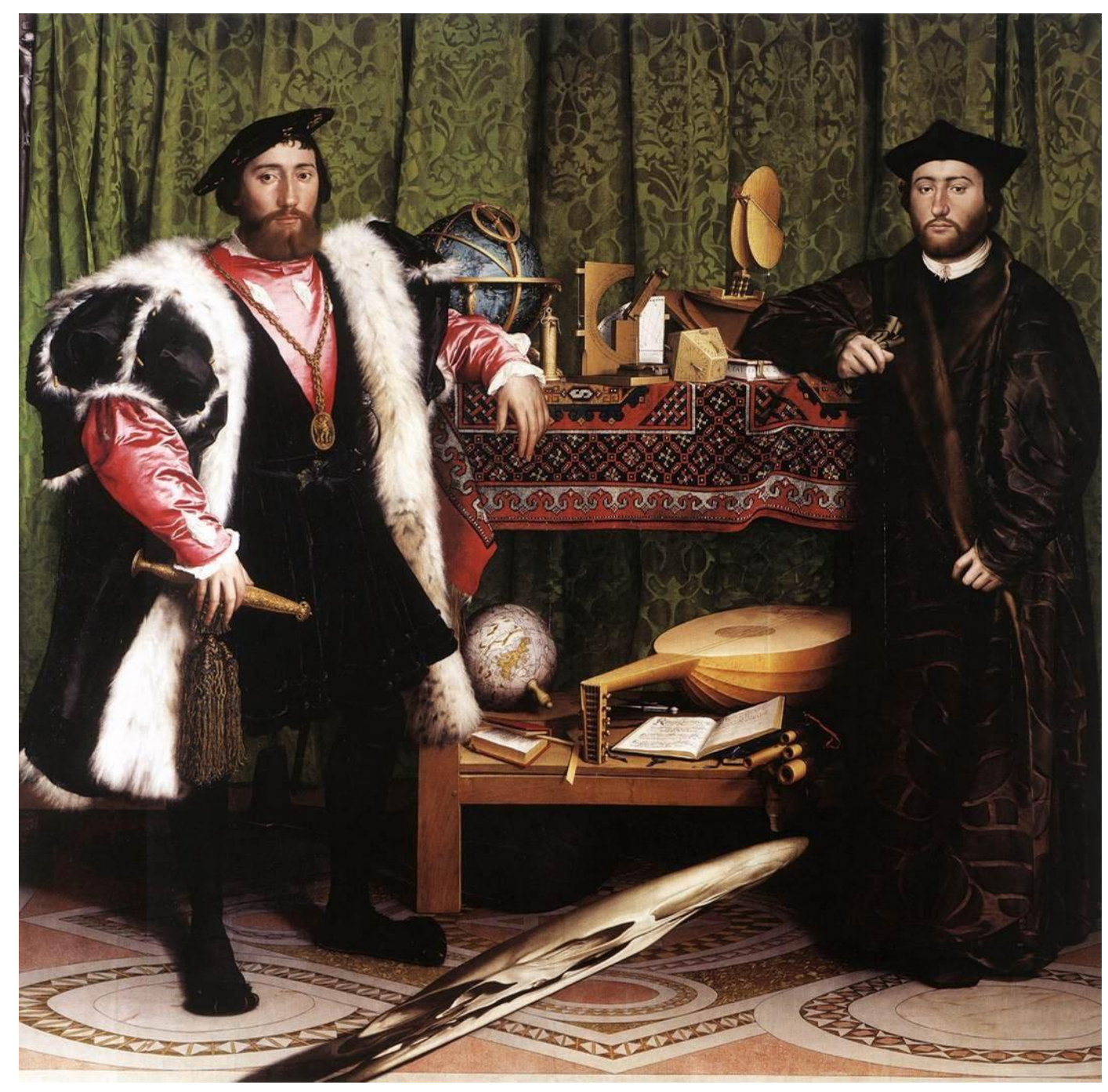

Figura 3. "Os embaixadores"- de Hans Holbein. Localização: National Gallery (Londres).

Disponível em: < http://www.ufscar.br/rua/site/?p=3042> acesso em: 10/12/2010.

O primeiro conceito de anamorfose formulado para as artes e o uso de distorção da imagem, toma consistência através de Jurgis Baltrusaitis ${ }^{11}$ ao analisar o quadro de Hans Holbein, que em 1533 introduz a figura de uma caveira à pintura de Die Gesandten (os embaixadores) de forma anamórfica.

\footnotetext{
11 Jurgis Baltrusaitis- historiador da Arte que irá colocar a discussão da representação artística, com o uso da anamorfose, no interior dos estudos artísticos ao analisar o quadro: "Os Embaixadores" de Hans Holbein - 1533. Disponível em: < http.//nww.eca.usp.br/caligrama/n_10/02_hassan.pdf >acesso em 24/08/2010.
} 
Baltrusaitis, após a análise do instrumento visual utilizado no quadro para gerar esta distorção na imagem, conceitua a anamorfose como:

[...] "um efeito perspectivo utilizado na arte para forçar o observador a um determinado ponto de vista preestabelecido ou privilegiado, desde o qual o elemento toma uma forma proporcionada e clara". (HASSAN,p.4)

(BALTRUSAITIS apud MACHADO, 1997, p. 56) alega que: "A perspectiva deixa de ser encarada como uma ciência da realidade para tornar-se um instrumento gerador de alucinações".

As perspectivas geométricas anteriores - a geometria euclidiana - esta, para Baltrusaitis, definitivamente dá lugar a essas novas perspectivas que surgiam. Arlindo Machado vai interpretar os conceitos de Baltrusaitis sobre anamorfose e sua utilização.

"Basicamente, as técnicas clássicas de anamorfose consistem num deslocamento do ponto de vista a partir do qual uma imagem é visualizada, sem eliminar, entretanto, a posição anterior, decorrendo daí um desarranjo das relações perspectivas originais. Em outras palavras, a anamorfose, nasce de uma duplicidade de pontos de vista na construção de uma imagem". (MACHADO, 1997, p.58)

O uso de anamorfoses nas artes acompanhou os desenvolvimentos técnicos contemporâneos a cada período artístico, ora usando recursos mais simples, como o uso de um espelho, ora lançando mão de recursos tecnológicos mais sofisticados e computacionais. Mas a oferta de outra forma de interação com o objeto visual, a oferta de outra forma de conexão com os sentidos é uma exigência para o uso deste instrumento visual.

Christian Metz (1973, p.15) ao citar Jean Louis Schefer, faz uma analogia entre os conceitos de imagem apresentados por ele e a colocação de Schefer: "... a imagem não é a imagem de um objeto, mas a do trabalho de produção da imagem".

No conceito de imagem de Schefer poderíamos introduzir a produção de anamorfoses cartográficas e entende-las como imagem. Não uma imagem com aptidões topográficas, mas a imagem da produção de representação de determinados objetos. 
O nome do holandês Mauritus Cornelis Escher ${ }^{12}$ (1898-1970) tornou-se um ícone quando se busca trabalhar com produções artísticas, que trazem em si o uso de representações gráficas. Suas obras foram e ainda são muito apreciadas pelos matemáticos, que veem nelas um total conflito com as lógicas da perspectiva.

Escher trabalhou seus quadros de forma a desafiar as leis da representação bidimensional, oferecendo outro olhar ao expectador ou mesmo a possibilidade de oferecê-lo. Transportou para os seus desenhos estruturas matemáticas complexas conseguiu unir arte e ciência e deu origem ao que foi posteriormente chamado de arte-matemática.

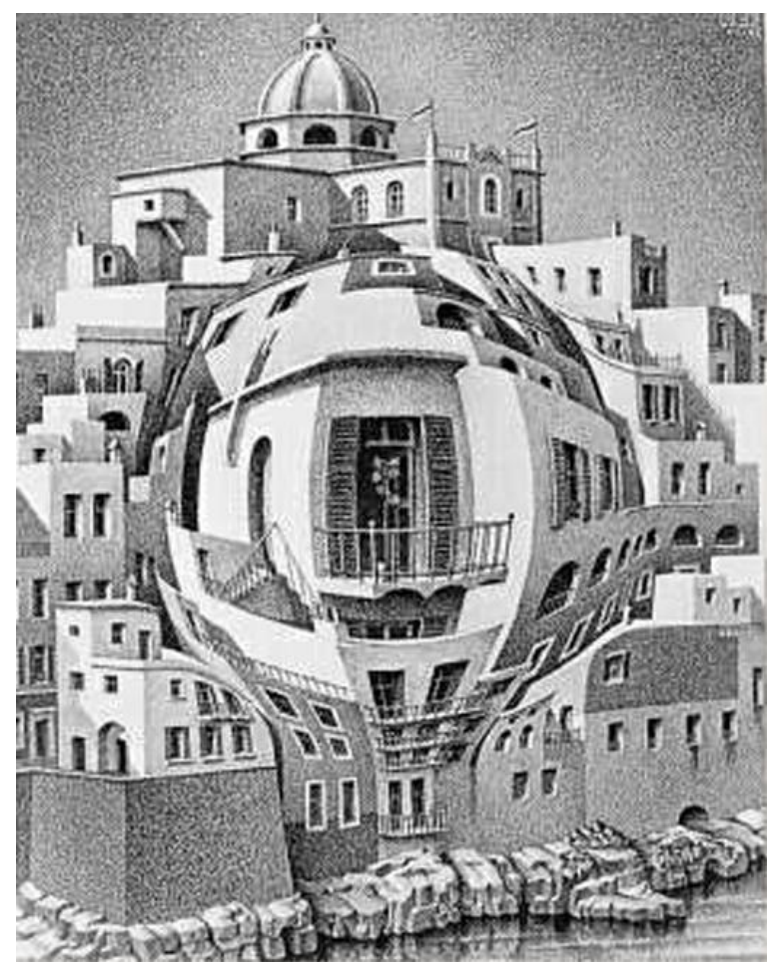

Figura 4. "Varanda" de Mauritus Cornelis Escher - obra intinerante.

Disponível em: http://saitedaqui.blogspot.com/2008_01_01_archive.html acesso em: 10/12/2010.

A produção do quadro "A Varanda" ou "Sacada" de Escher utiliza uma técnica semelhante as da construção das atuais anamorfoses cartográficas, com o uso de uma grade de referência e a ampliação de determinadas áreas de destaque visual, prática muito comum encontrada nos softwares que trabalham com anamorfose.

\footnotetext{
12 Mauritus Cornelis Escher - Estudou Arquitetura, mas foi através de seu professor de artes gráficas, Jesserum de Mesquita que descobriu o seu gosto pela artes. Sua arte foi apreciada pelos matemáticos, embora Escher nunca tenha se aproximado da matemática como disciplina acadêmica. Disponível em: http://www.educ.fc.ul.pt/icm/icm2000/icm33/Escher.htm acesso em 21/06/2010
} 

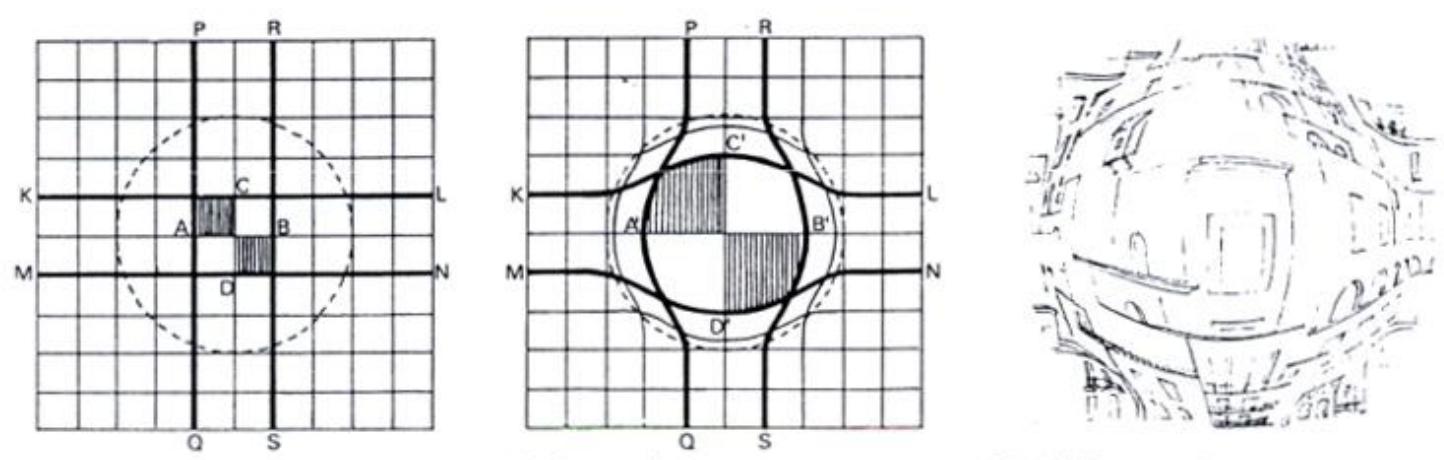

Figura 5. Escopo de "Varanda" disponível em:

<http://www.educ.fc.ul.pt/docentes/opombo/seminario/escher/varanda.html> acesso em: 21/06/2010

A anamorfose vista através das artes contribui para incluir uma reflexão cartográfica da forma e do espaço. Relativizar o olhar sobre o objeto e pensar outras formas de representa-lo visualmente. Essas novas perspectivas apresentadas pelas artes, oferecem uma mudança de conceitos lógicos que podem transitar com facilidade entre as disciplinas que buscam representar 0 espaço geográfico com o uso de métricas diversas.

\subsection{A anamorfose na escola}

Dentro da disciplina matemática, os PCNs (Parâmetros Curriculares Nacionais), matrizes básicas para a educação da Matemática no Brasil, apresentam uma visão de espaço já bastante aceita na sua prática:

[...] fruto da criação e invenção humanas, a Matemática não evolui de forma linear e logicamente organizada. Desenvolvese com movimentos de idas e vindas, com rupturas de paradigmas. Frequentemente um conhecimento é amplamente utilizado na ciência ou na tecnologia antes de ser incorporado a um dos sistemas lógicos formais do corpo da Matemática. Exemplos desse fato podem ser encontrados no surgimento dos números negativos, irracionais e imaginários. Uma instância importante de mudança de paradigma ocorreu quando se superou a visão de uma única geometria do real, a Geometria Euclidiana, para aceitação de uma pluralidade de modelos geométricos, logicamente consistentes, que podem modelar a realidade do espaço físico. (BRASIL, MINISTÉRIO DA EDUCAÇÃO, PCN-Matemática - $5^{a}$ serie - 1998, p. 24).

A transição da visão espacial através da geometria euclidiana para outras formas de representação ocorreu de forma truncada e de difícil 
aceitação, falando no contexto geográfico, mas parece bastante estruturado para a Matemática - disciplina que trabalha de forma racional e lógica. Vemos nos PCNs de Matemática para ensino fundamental II esta visão de espaço como amplamente aceita e capaz de ser trabalhada com alunos desde a faixa etária dos 11 aos 14 anos.

Porém é importante salientar que a aceitação deste recurso cartográfico (anamorfose) não é isento de uma mudança de paradigma para a aceitação de uma cartografia que esteja envolvida com uma essência geográfica e não somente com uma valorização da forma e da precisão das localidades espaciais.

Nos PCNs (Parâmetros Curriculares Nacionais) de Geografia temos a contribuição da cartografia para a formação do aluno, de um aluno crítico e consciente, uma visão que vai além da prática de copiar mapas e identificar localizações precisas.
"Atualmente, comprometida com as novas correntes do pensamento de uma Geografia da percepção e fenomenológica, o aluno passou a ser orientado a desenvolver uma consciência crítica em relação ao mapeamento que estará realizando em sala de aula. Isso significa dizer que existe sempre uma perspectiva subjetiva na escolha do fato a ser cartografado, marcado por um juízo de valor. O aluno deixou de ser visto como um mapeador mecânico para ser um mapeador consciente, de um leitor passivo para um leitor crítico dos mapas". (BRASIL, MINISTÉRIO DA EDUCAÇÃO, PCN - Geografia - 1998, p. 77).

Maria Elena Ramos Simielli (2006, p.96) apresenta a importância da "alfabetização cartográfica" para uma apreensão do mapa entre os alunos do ensino fundamental e médio. Coloca como fundamento inicial proporcionar, através de um método dedutivo, uma familiarização com os componentes espaciais apresentados.

"Em primeiro lugar, aproveitando o interesse natural das crianças pelas imagens desde as séries iniciais, que é uma atitude fundamental para a cartografia. Para atingir esse objetivo, devemos oferecer inúmeros recursos visuais, desenhos, fotos, maquetes, plantas, mapas, imagens de satélites, figuras, tabelas, jogos e representações feitas por crianças, acostumando o aluno a imagem visual". (SIMIELLI, 2006, p.97) 
O uso de uma diversidade de imagens para uma apreensão espacial amplia, ao aluno, as formas e possibilidades de se relacionar com este espaço. SIMIELLI (2006, p.101) chama de "aluno mapeador consciente" aquele aluno que participa do processo de produção de uma representação espacial (maquetes, croquis e mapas mentais), possibilitando a este o uso de sua percepção, criatividade e aplicação cognitiva.

Em particular, os mapas mentais que possibilitam aos alunos o uso de diversas métricas para representar o seu cotidiano, onde a posição dos objetos é relativa, além das relações de proximidade espaciais físicas, as relações com as métricas, tempo, custo e interesses são exemplos de possibilidades a serem manipuladas cartograficamente.

Colocar a aprendizagem pelo mapa em uma associação direta com a cartografia que aproxima os objetos sociais de uma prática exequível que se utiliza de códigos simplificados da linguagem.

Ao se considerar o mapa como linguagem performante e, também as imagens como meios de comunicar e refletir as novas estruturas do urbano, a cartografia tem uma tarefa no que diz respeito à pesquisa e ao ensino da Geografia, visto que o mapa esquematiza a apreensão do espaço geográfico das cidades.

Vermos a cidade de São Paulo e sua composição espacial através de mapas em anamorfose, tal como apresentaremos nesta dissertação, pode requerer certo esforço analítico e um direcionamento adequado de intenções de uso para estes mapas.

"Mapas são ativos; eles constroem ativamente o conhecimento, exercem poder e podem ser poderosos meios para promover a transformação social". (CRAMPTON e KRYGIER,2008, p.98) 


\title{
CAPITULO 2 - 0 espaço da cidade
}

Um breve histórico do surgimento das cidades nos mostra que sua existência ocorreu, provavelmente, com o domínio de determinadas técnicas agrícolas, que possibilitaram a existência de um excedente agrícola, ou seja, um aumento da produção de alimentos que dispensava mão de obra agrícola, direcionando-as para atividades diferenciadas nas cidades.

\begin{abstract}
"As cidades puderam formar-se graças a um determinado avanço das técnicas de produção agrícola, o qual propiciou a formação de um excedente de produtos alimentares. Com a existência deste excedente, algumas pessoas puderam dedicar-se a outras atividades, sendo a cidade, predominantemente, lugar de atividades não agrícolas." (SANTOS, 1988, p. 53)
\end{abstract}

"No séc. III a.C., um camponês egípcio podia produzir uma quantidade de alimento três vezes maior que a que necessitava para o seu sustento. Não sabemos se foram esses excedentes que deram origens a instituições como a cidade ou se a instituição da cidade motivou a criação e manutenção de excedentes. Provavelmente os dois efeitos foram simultâneos. De qualquer forma o resultado foi o aparecimento das primeiras cidades."

(PALEN, 1975, p.30)

Mesmo que imprecisa em sua origem o termo cidade está diretamente relacionado a ajuntamento de pessoas, mesmo que ajuntamentos primitivos. "Mesmo Atenas no seu apogeu tinha apenas 250 ha. dentro dos seus muros, cidades anteriores ao período romano não podiam ter uma população maior que 200.000 habitantes" (PALEN, 1975, p.32). De acordo com o que se pode inferir das pesquisas feitas pelo mesmo autor, o tamanho das cidades e 0 número de habitantes não foram, no princípio, elementos de grande importância para a utilização do termo "cidade", mas sim, a proximidade destes grupos populacionais e a evolução das atividades desempenhadas pelos citadinos que permitiam surgirem complexidades organizacionais dentro de um novo modo de vida, a vida urbana, adensada. 
Nos trabalhos de Lewis Mumford (1965, p.13) vemos que para se chegar à origem das cidades devemos ir além dos trabalhos dos arqueólogos e encontrar "a existência de uma ordem urbana".

Luis Wirth (1973) sugere-nos que o modo de vida urbano é influenciado por outros elementos, além da proporção da população.

"As influencias que as cidades exercem sobre a vida social do homem são maiores do que poderia indicar a proporção da população urbana, pois a cidade não somente é, em graus sempre crescentes, a moradia e o local de trabalho do homem moderno, como é o centro indicador e controlador da vida econômica, política e cultural que atraiu as localidades mais remotas do mundo para dentro de sua órbita e interligou as diversas áreas, os diversos povos $e$ as diversas atividades num universo." (WIRTH, 1973, p.90).

Na obra de WIRTH lemos que a cidade é um modo distinto de vida dos agrupamentos humanos. Através das análises de Wirth, podemos listar uma relação de elementos, que seriam necessários para que haja um espaço específico denominado "cidade":

\begin{tabular}{|c|c|c|c|}
\hline Tamanho & \multirow{3}{*}{$\begin{array}{c}\text { “esperando-se que a } \\
\text { amplitude das diferenças } \\
\text { cresça proporcionalmente à } \\
\text { quantidade" - Gerando } \\
\text { contatos }\end{array}$} & \multirow{3}{*}{$\begin{array}{l}\text { Levando ao } \\
\text { superficialismo, ao } \\
\text { anonimato e ao } \\
\text { caráter transitório das } \\
\text { relações urbano- } \\
\text { sociais. }\end{array}$} & \multirow{3}{*}{$\begin{array}{c}\text { O que conduz } \\
\text { estes espaços } \\
\text { a uma } \\
\text { ampliação de } \\
\text { seus mercados } \\
\text { e uma } \\
\text { necessidade de } \\
\text { especialização }\end{array}$} \\
\hline Densidade & & & \\
\hline Heterogeneidade & & & \\
\hline
\end{tabular}

Quadro 1 - Os elementos constituidores de uma cidade - quadro elaborado pela autora de acordo com as sínteses de Luis Wirth (1973, p.98).

A necessidade de adensar as diversidades culturais, sociais e funcionais, parece estar presente quando se trata de conceituar a cidade, não apenas para formação de um limite político administrativo do município, mas como uma construção; como um modo de vida. 
Wirth (1973, p.96) define a cidade como sendo "Um núcleo relativamente grande, denso e permanente, de indivíduos socialmente heterogêneos".

Jaime Tadeu Oliva apresenta uma explanação teórica do conceito de cidade e de urbano, porém ainda salientando a necessidade de maior discussão sobre este tema no interior da Geografia.

“É perceptível a fragilidade existente no próprio núcleo da conceituação de cidade e de urbano, ocultada por um certo consenso mudo que entende que essa questão nem existiria." (OLIVA, 2004, p.71)

Mesmo antes de nos oferecer um conceito do que, na visão de Oliva, vem a ser cidade, ele nos oferece uma gama de questionamentos relevantes à prática cartográfica, ao analisar conjuntamente os temas cidade e urbano, desenvolvendo uma linha de raciocínio lógico entre os dois conceitos espaciais.

"Haveria essa distinção entre o urbano e a cidade? As cidades coexistem com um urbano que as ultrapassam, mas a despeito disso, poderiam resistir a esse urbano fragmentado?" (OLIVA, 2004, p.71)

Se, a resposta à primeira questão fosse afirmativa e o urbano fosse contemplado como sendo um modo de viver social produzido pelas densidades e diversidades existentes e a cidade o lugar onde este urbano se manifesta, então, a resposta à segunda questão também seria afirmativa: os limites não poderiam conter uma manifestação de modo de vida social dentro de fronteiras previamente estabelecidas. Contudo ainda, o conceito de cidade não poderia estar simplesmente anexado ao conceito de município (limite político administrativo - contorno). Se utilizarmos a origem das cidades e confrontarmos a sua vocação natural, com essa forma de conceituar este espaço, concluiríamos que diversos conceitos de cidade, não explicam a cidade, muito menos esse urbano fragmentado.

O próprio conceito de cidade deve transcender a esse limite político se estiver atrelado às exigências apresentadas, de densidade e diversidade, ou mesmo podendo ser fragmentada dentro de um todo que não a suporte, como é o caso do município de São Paulo, que graças a sua extensão e diversidade espacial, não comportaria o termo cidade apenas em sua extensão e nem 
mesmo em toda ela. Como nos apresenta Oliva ao conceituar a cidade como sendo:

[...] um conjunto de máxima concentração e de máxima diversidade de objetos geográficos que favorece e acomoda grandes contingentes populacionais em distância mínima e atua como estimuladora de relações societais. (OLIVA, 2003, p.73)

Relações societais, relações de anonimato, uma dimensão do urbano, característica das cidades, uma relação que se afasta das relações de comunidade, das relações de privilégios e está liberta de determinadas regras privadas ao se aproximar da impessoalidade.

"O societal caracteriza-se por uma diversidade com alteridade significativa, num nível que não impede que se constitua uma sociedade. Com sua substância societal, a cidade promove e modifica qualitativamente as interações sociais". (OLIVA, 2004, p.72)

"O lócus de produção da cartografia é societal, na medida em que ele concerne, ao mesmo tempo, o conhecimento teórico e a vida cotidiana, a linguagem e a tecnologia, o econômico e o político" (LEVY,2008, p.153)

Em outra definição bastante extensa, porém muito elucidativa, temos a cidade como um "ator social" - o que é e como atua a cidade gerando urbanidade - modo de vida da cidade, a importância de portar densidade e diversidade para gerar um espaço singular.

"Os atos de relacionar-se e coexistir são as condições universais e fundamento do ser social. Intensificar essas relações com um grau elevado de diversidade (e é isso que define o nível de urbanidade) é algo que a ocorrência das cidades favoreceu e tornou exponencial, por isso podemos nos referir à cidade como espaço produtivo, como ator social. A coexistência permite à cidade ser 0 lugar do encontro da diferença, o que abre as chances para que se superem, ao menos em parte, as segregações sociais e econômicas, culturais e étnicas. A possibilidade dessa convivência significa uma aprendizagem progressiva de posturas orientadas pelo entendimento, pelo acordo, pela tolerância. A cidade com urbanidade, logo, contém uma dimensão ética, forjada pela necessidade de coexistência pacífica e cotidiana com a diferença. Pode-se até dizer que a cidade é a condição espacial da realização dos valores libertários modernos e da configuração dos direitos do homem. Ela produz a estimulação cultural, ela produz conhecimento. 
A inteligência não respira e não prolifera em ambientes onde predominam os padrões (a uniformidade de pensamento) que são sempre muito constrangedores. Quando essa produtividade potencial da cidade decai, são as práticas anti-cidade, marcadas pela segregação e uniformização que estão operando e rebaixando a urbanidade". (OLIVA, 2003, p.74).

Buscamos através da cartografia evidenciar dentro dos distritos do município de São Paulo a existência da cidade, esta cidade diversa, generosa e instrumentada, capaz de produzir conhecimento, cultura e diminuir desigualdades. Ou denunciar os espaços, que correm às margens dessa urbanidade, na metrópole paulistana.

O uso da anamorfose nas produções de nossos mapas serve para esclarecer que, simplesmente "poligonizar" as fronteiras de intensidade e aglomerações urbanas (como apresentado no mapa 5) não são suficientes para se revelar as cidades dentro da cidade, são apenas recortes mudos de localizações específicas. "Existem duas ou diversas cidades dentro da cidade. Esse fenômeno é o resultado da oposição entre níveis de vida e entre setores de atividade econômica, isto é, entre classes sociais" (SANTOS, 2008, p.190). Principalmente porque há diversos fenômenos a serem analisados.

Uma constatação que se fará evidente é que o tamanho da região do estremo Sul, será na maioria das vezes minimizado, visto que essa área geográfica possui poucos índices de urbanidade, tratando-se em sua maioria de uma região de Parques como o PESM (Parque Estadual da Serra do Mar), o que na cartografia tradicional causa um grande impacto visual devido a sua grande extensão.

Salientando que para a nossa cartografia "social" o simples tamanho de uma região, que possui baixos índices sociais, pode mais confundir do que explicar, gerando as mesmas contradições do "mapa tradicional das eleições suíças" (mapa 1). Chamando a atenção ao que Brian Harley denominou de silêncio dos mapas:

"Os "silêncios" dos mapas são um conceito central em toda argumentação concernente à influência de suas mensagens políticas ocultas. Afirma-se aqui que, assim como certos exemplo de escritas ou de falas, os mapas exercem uma influência social, tanto por suas omissões 
quanto pelos elementos que elas representam e valorizam". (HARLEY, 1995, p. 14)

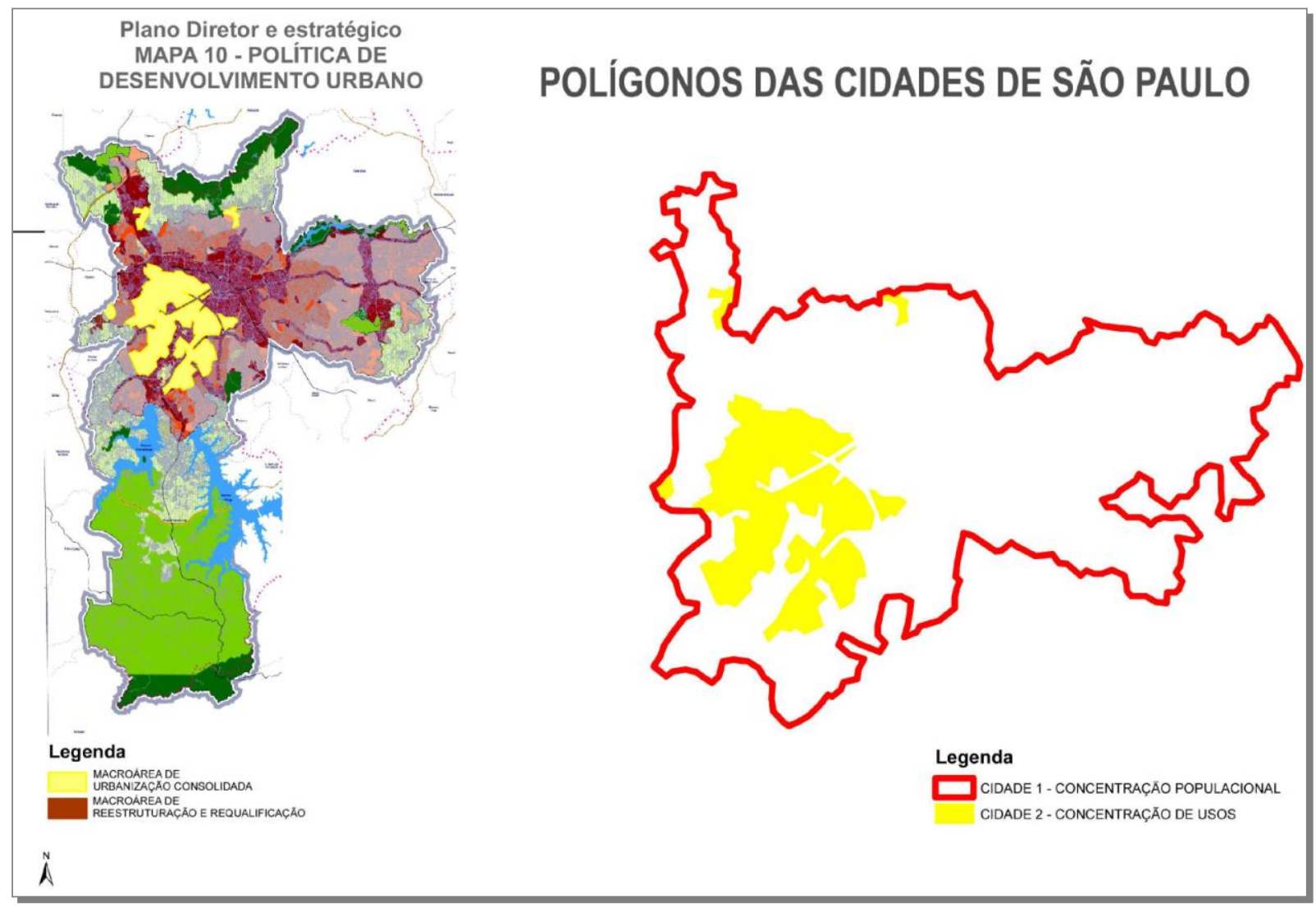

Mapa 5 - Polígonos da Cidade de São Paulo - mapa elaborado pela autora através de uma análise do mapa 10 do Plano Diretor e estratégico do município de São Paulo. 


\section{CAPITULO 3 - Elementos de análise para a cidade de São Paulo}

\subsection{A mobilidade}

No Manual de Geografia Urbana (2008), Milton Santos apresenta no capítulo 13 uma análise da cidade de Abadã no Irã, como uma forma de elencar algumas características reveladoras do espaço da cidade. Buscamos, mesmo que apenas como eixo metodológico, seguir estas instruções de análise. Milton Santos também nos coloca a questão das transformações do espaço habitado como revelador de um modo de vida humano.

"O fenômeno humano é dinâmico e uma das formas de revelação desse dinamismo, está exatamente na transformação qualitativa e quantitativa do espaço habitado". (SANTOS, 1988, p.37).

David Harvey traz uma visão diferenciada para a análise social e espacial da cidade, considerando inclusive as sensações sociais construídas.

"A aparência de uma cidade e o modo como os seus
espaços se organizam formam uma base material a partir
da qual é possível pensar, avaliar e realizar uma gama de
possíveis sensações e práticas sociais". (HARVEY, 1992,
p.69).

E finalmente para embasar as nossas escolhas de elementos de análise que servirão a nossa produção cartográfica, está a importância de se analisar o viver e o vivido apresentados por Odete Seabra:

“... o cotidiano se refere, em princípio, ao ciclo do tempo, de que a vida cotidiana é própria de nossa época (funde o viver e o vivido) e de que a cotidianidade é o ritmo estabelecido na dialética do viver e do vivido, restando, por considerar, no interior desse movimento contraditório, primeiro, a manifestação dos modos de vida no cotidiano; depois uma breve consideração da vida cotidiana como unidade de espaço e de tempo". (SEABRA, 2004, p.193).

Com a escolha da mobilidade como um dos instrumentos operacionais, capazes de revelar a cidade, justificamos a sua importância ao atribuirmos a essa mobilidade as conexões sócio-espaciais capazes de serem realizadas.

Entendemos a mobilidade como a dinâmica, os movimentos existentes 
na cidade e a capacidade de acesso, físico, ou seja, real, através das redes de transportes - ou virtual, através das tecnologias de comunicação e informação.

\begin{abstract}
"A mobilidade torna-se possível porque existe uma oferta de mobilidade, a acessibilidade. A mobilidade é efetiva porque os seus operadores possuem uma competência de mobilidade. A mobilidade tem sentido porque, no quadro do domínio do espaço, ela entra na composição do capital social dos indivíduos". (LEVY, 2000, p.3).
\end{abstract}

Neste mesmo artigo Jacques Lévy destaca como cada pessoa pode "inventar a sua cidade, escolhendo os lugares que the interessam, e eliminando outros". É evidente que essa escolha, muitas vezes é imposta ao morador da cidade através de contingências que vão desde disponibilidade de trabalho, acesso a moradia e aos meios de transporte, até a própria oferta de atividades oferecidas pela cidade.

\title{
3.1.a - A mobilidade real paulistana
}

A aquisição de um capital espacial capaz de revelar um espaço do cidadão e sua territorialidade, não está a critério da sociedade, mas de uma cidade como organizadora da vida urbana. Entretanto "uma cidade permite até certo ponto a cada citadino «fabricar» a sua cidade e que, justamente a oferta de mobilidade constitui um instrumento decisivo dessa margem de liberdade". (LEVY, 2000, p. 3).

No (mapa 6) onde é apresentada uma média do tempo utilizado pelos moradores da cidade para se chegar ao trabalho, a mais cotidiana de suas mobilidades, vemos uma separação clara entre as áreas mais periféricas das áreas mais centralizadas. O que fica muito mais notável no (mapa 7) onde podemos explicar um dos motivos dessa separação espacial, a métrica tempo, a quantidade de tempo de deslocamento para o trabalho, comparado à oferta de trens da CPTM (Cia Paulista de Trens Metropolitanos) e do Metrô (Cia do Metropolitano de São Paulo).

A oferta limitada de transporte sobre trilhos torna a cidade menos fluída, ou mesmo, menos cidade, afastando as áreas mais periféricas das possibilidades de aquisição de uma das características que a definiriam como 
cidade: diversidade. Fica notável a qualidade de mobilidade existente para os moradores dos distritos atendidos por esses meios de transporte; utilizando a métrica tempo, mesmo ainda sendo questionada a qualidade e a quantidade destes transportes, falando principalmente dos trens da CPTM.

Em um município com mais de dez milhões de habitantes transitando diariamente, não é difícil imaginar a importância de um transporte subterrâneo.

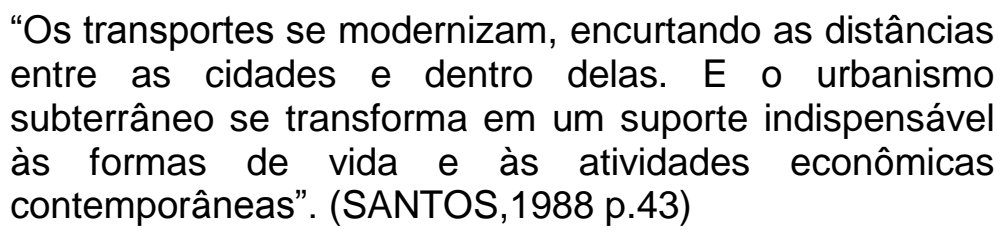

Não nos aprofundaremos nesta dissertação, mas não nos é caro verificar dentro da história da produção do espaço, município de São Paulo, a formação dos bairros acontecendo ao longo das estações de trem. A diversidade social, econômica e cultural proporcionada pelos transportes sobre trilhos na formação histórica da cidade. Não nos furtando reconhecer a evidente degradação das áreas, que ao longo dos trilhos, não são servidas por estações e mesmo das cisões ocorridas nos espaços por onde passam estes trilhos. Contudo, vemos que esses problemas ocorrem pelo abandono dessas áreas para as melhores servidas de transportes coletivos, pela substituição do uso dos transportes coletivos pelo uso do automóvel particular, e principalmente pela pouca oferta de diversidade de atividades dessas áreas.

Vemos agora o automóvel, que evidentemente é o maior causador dos problemas de congestionamento em São Paulo, que diariamente dificulta um acesso mais rápido das pessoas aos seus destinos, fica na maioria das vezes fora das discussões sobre melhoria da fluidez em São Paulo. Não é raro ouvirmos pessoas comentando que "a cidade poderia ser sempre como no domingo" (com poucos carros na rua) ou mesmo "como nos feriados" (ainda se referindo aos automóveis particulares), não é comum ouvirmos que deveria haver menos ônibus ou menos metrô ou trens.

Jaime Oliva discute a prática "ideológica" que exclui o automóvel como um problema a ser analisado e trabalhado:

"E aqui está a chave da força ideológica do automóvel: ele fica no limbo quando o assunto é o transporte da 
cidade. Ao falar-se,... de transporte entendeu-se apenas transporte coletivo, como se os automóveis não representassem uma forma de transporte que deve ser alvo de políticas ordenadoras. Talvez, por ser um bem privado considera-se que o automóvel não deva ser alvo de políticas". (OLIVA, 2004, 65)

Mesmo com a oferta de outros meios de transportes coletivos no município de São Paulo, como ônibus e vans, além dos transportes sobre trilhos, já mencionados, podemos verificar no (mapa 8) que a qualidade de mobilidade está diretamente relacionada ainda, a oferta de metrô - além da diminuição do tráfego de automóveis - a oferta de Metrô está limitada a alguns poucos quilômetros, nas regiões centrais do município. O metrô que desde sua fundação em 1968 até agora só percorrem 61,3 quilômetros de linhas e que ainda não faz jus ao seu nome (Cia do Metropolitano de São Paulo), pois não consegue atender nem mesmo a todo o município de São Paulo, quanto mais ao seu entorno metropolitano.

No (mapa 9) onde há a comparação entre a oferta de transportes coletivos - é preciso tomar cuidado, pois o correto é mesmo transporte "coletivo" e não "público" - já que cabe a SPTRANS (São Paulo Transportes S.A.) a administração das empresas de ônibus, que somam 15 mil ônibus e 1.300 linhas na cidade de São Paulo. Mesmo com toda essa frota, vemos no mapa que a satisfação dos moradores das áreas mais afastadas do centro ainda está distante de um ideal, comparando as áreas centrais, com a oferta do Metrô.

Teresa Pires do Rio Caldeira (2000, p.218) fala sobre a forma de organização espacial da cidade na relação Centro/Periferia, coloca que "o sistema de transporte baseia-se no uso de ônibus para as classes trabalhadoras e automóveis para as classes média e alta”. Caldeira estabelece a relação entre a ocupação das áreas mais afastadas do centro, pela especulação imobiliária concomitantemente a inserção das linhas de ônibus, privadas, nestas áreas não servidas pelo trem e áreas que a princípio eram áreas de difícil acesso, pela falta de equipamentos urbanos - ruas e avenidas. Característica que pode, ainda hoje, ser atribuída a alguns lugares da periferia de São Paulo. 
No (mapa 10) vemos que a conservação das ruas e avenidas também apresenta insatisfação por parte dos moradores das áreas mais afastadas, notamos também uma insatisfação no que chamamos de Centro Velho da cidade. Deixando apenas as áreas que margeiam o Centro Velho, conhecidas como Centro Expandido como possuidoras das melhores notas. Estes espaços com os índices sobre a conservação de ruas e avenidas é muito semelhante ao (mapa de "Renda acima de 5 Salários Mínimos"), usado aqui para tentar associar: maior renda - com - melhor conservação das ruas e uso do automóvel. Deixamos claro que não associamos a mobilidade com a renda e sim descrevemos uma situação espacial de qualidade da oferta de acessibilidade com a possibilidade do uso do automóvel, sua preferência mediante essa oferta.

O comparativo do (mapa 11), nos mostra que a disparidade Centro/Periferia ainda é uma realidade dentro do município de São Paulo, quando se fala de transportes coletivos e também nos mostra a existência de uma outra centralidade, não mais o centro geográfico do município, são as novas centralidades.

Buscando nos afastar do que Jacques Lévy chamou de "uma visão tecnicista da intermodalidade" (LEVY, 2000, p. 3), trouxemos para esta discussão outros elementos relacionados à mobilidade, que não apenas a oferta de transportes coletivos. Mesmo porque observamos do (mapa 12) que a oferta maior de transportes coletivos (principalmente aquele sobre trilhos) não é suficiente para diminuição do trânsito na cidade de São Paulo, o que realmente nos mostra é que a oferta de diversidade de atividades, concentradas em algumas regiões amplia a ocorrência de trânsito - o que somente pode estabelecer relação com o uso do automóvel.

No (mapa 13) ao compararmos a ocorrência de trânsito com a conservação de ruas e avenidas podemos perceber um incentivo ao uso do automóvel nas áreas centrais da cidade em detrimento das áreas periféricas, já que nas regiões centrais as ruas são melhor conservadas, não excluindo as visões ideológicas para a escolha do uso dos carros particulares.

"Não se trata simplesmente de uma questão de distribuição desigual, de que algumas pessoas movimentem-se mais do que outras e que alguns tenham 
mais controle do que outros. Trata-se do fato de que a mobilidade e o controle de alguns grupos podem ativamente enfraquecer outras pessoas. A mobilidade diferencial pode enfraquecer a influência dos já enfraquecidos. A compressão tempo-espaço de alguns grupos pode solapar o poder de outros." (MESSEY, 2000, p.180).

Não buscamos estabelecer uma lógica econômica espacial de uso das áreas centrais e mais bem servidas de equipamentos de mobilidade, visto 0 grande e não recente, crescimento dos condomínios de luxo nas regiões periféricas da capital, mas sim uma lógica de acessibilidade, seja ela como uma possibilidade ou mesmo como uma condição libertária do direito à cidade. 


\section{TEMPO MÉDIO PARA CHEGAR AO TRABALHO SÃO PAULO - 2009}
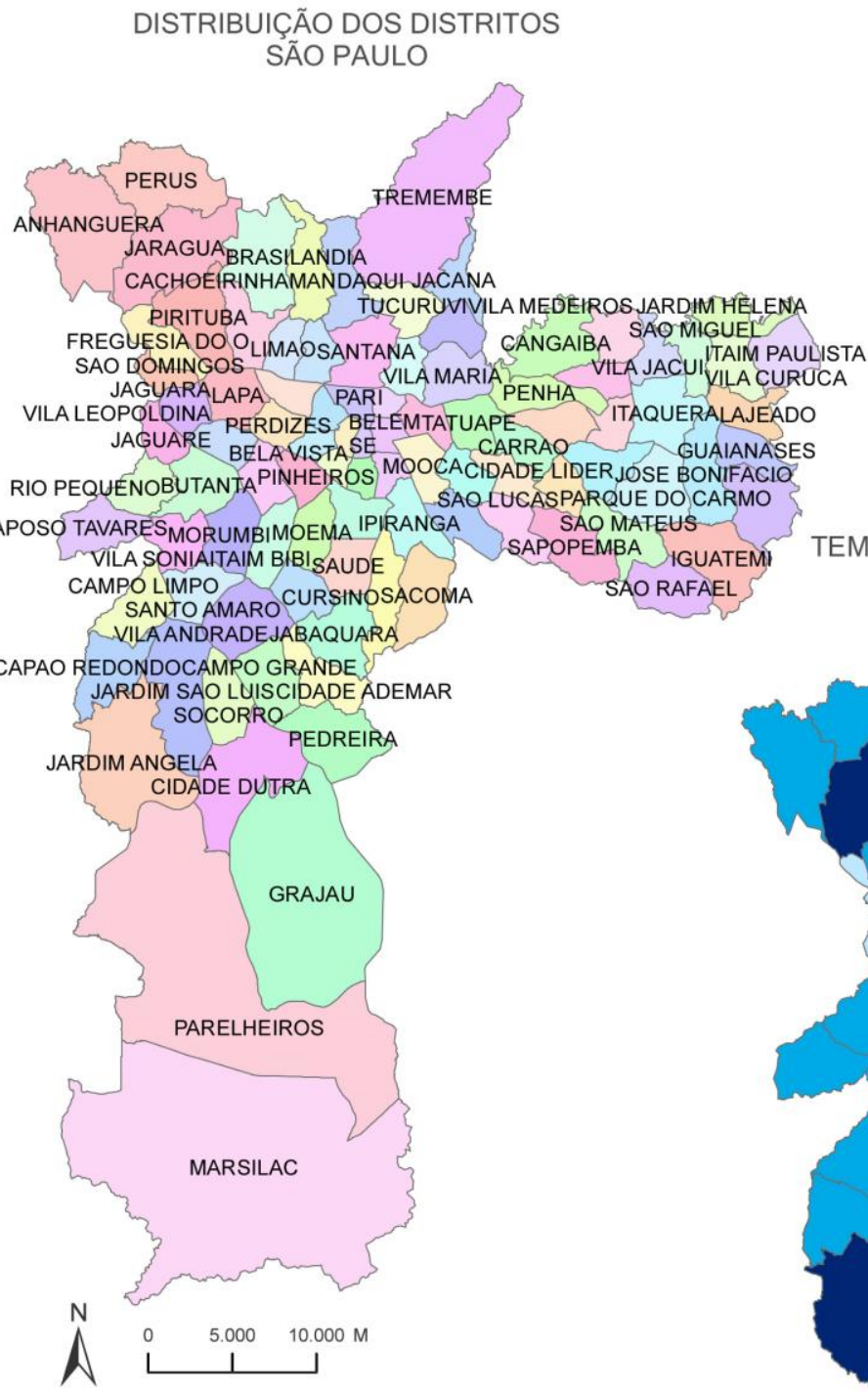

TEMPO MÉDIO PARA CHEGAR AO TRABALHO

SÃO PAULO - 2009

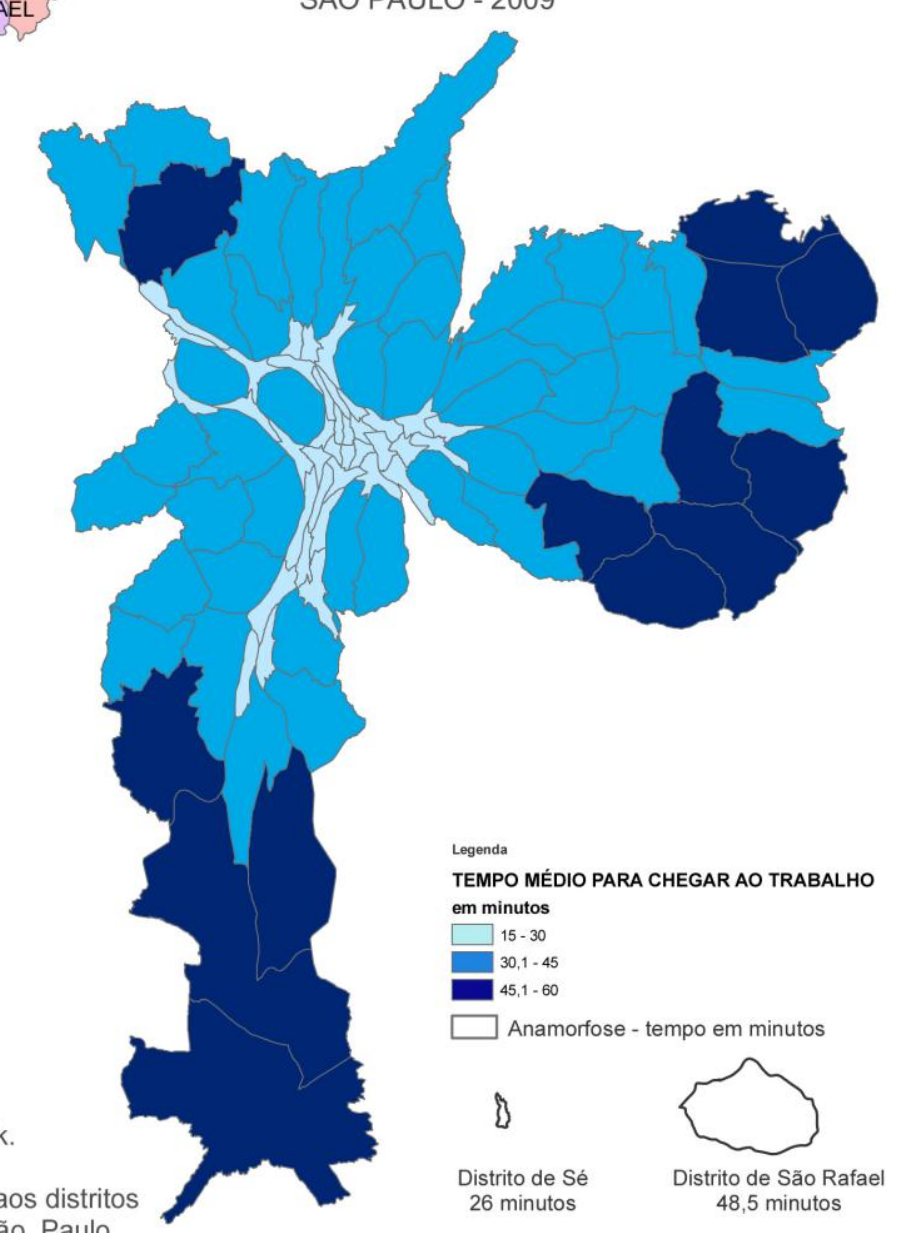

Elaborado por: Daniela Tobias - 2011

in: ArcGIS 9.2 ESRI

Anamorfose in:ScapeToad - software desenvolvido

por: Dominique Andrieu, Christian Kaiser e André Oureodnik.

direção do projeto: Jacques Lévy

Ordenado em: Jenks - utilizando a métrica tempo aplicada aos distritos

Fonte: DNA Paulistano - Datafolha - 2009 e Prefeitura de São Paulo

Mapa 6 - Tempo médio para se chegar ao trabalho - São Paulo 2009 


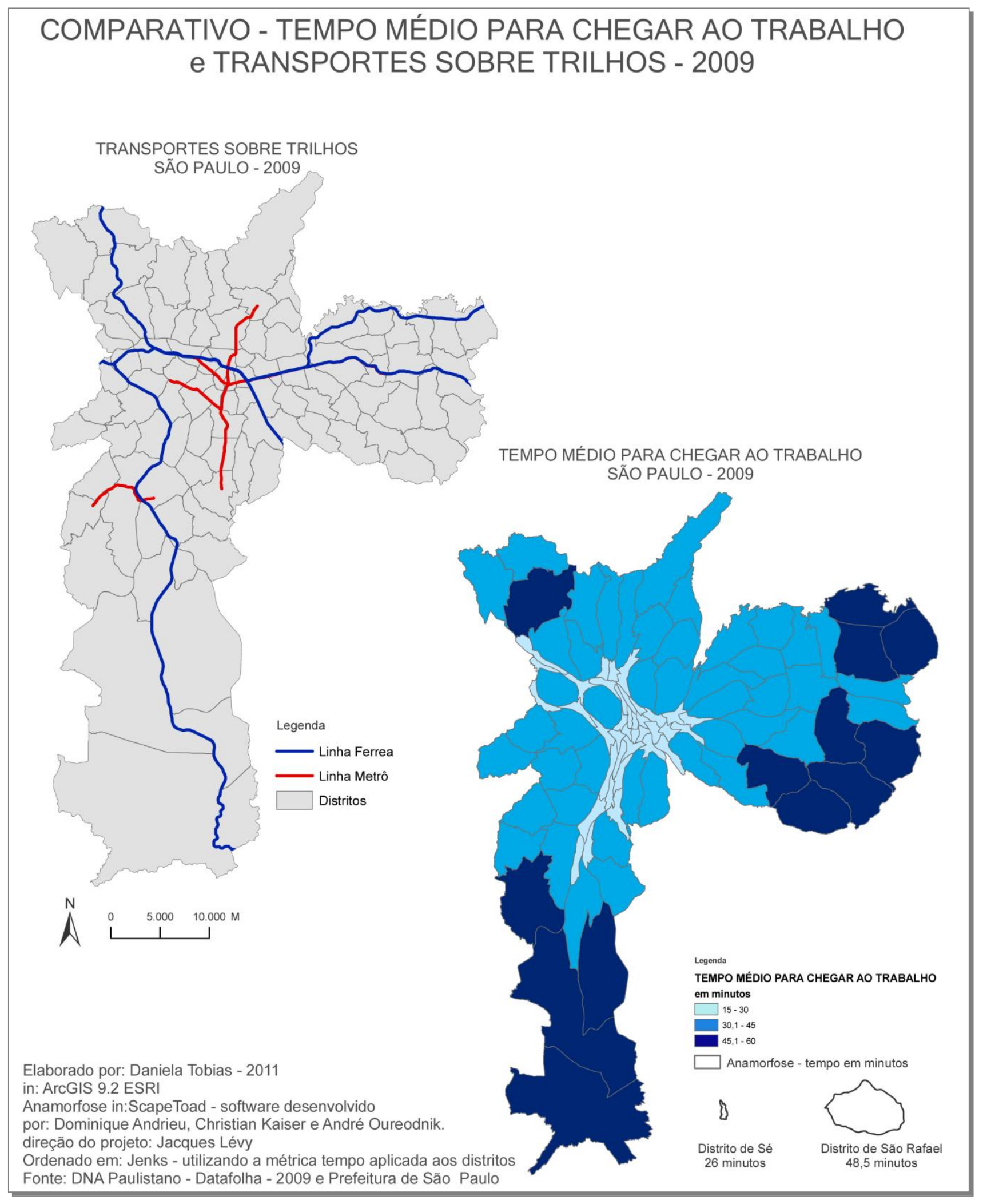

Mapa 7 - Tempo médio para se chegar ao trabalho - São Paulo 2009 comparado aos equipamentos de transportes sobre trilhos, oferecidos no município. 


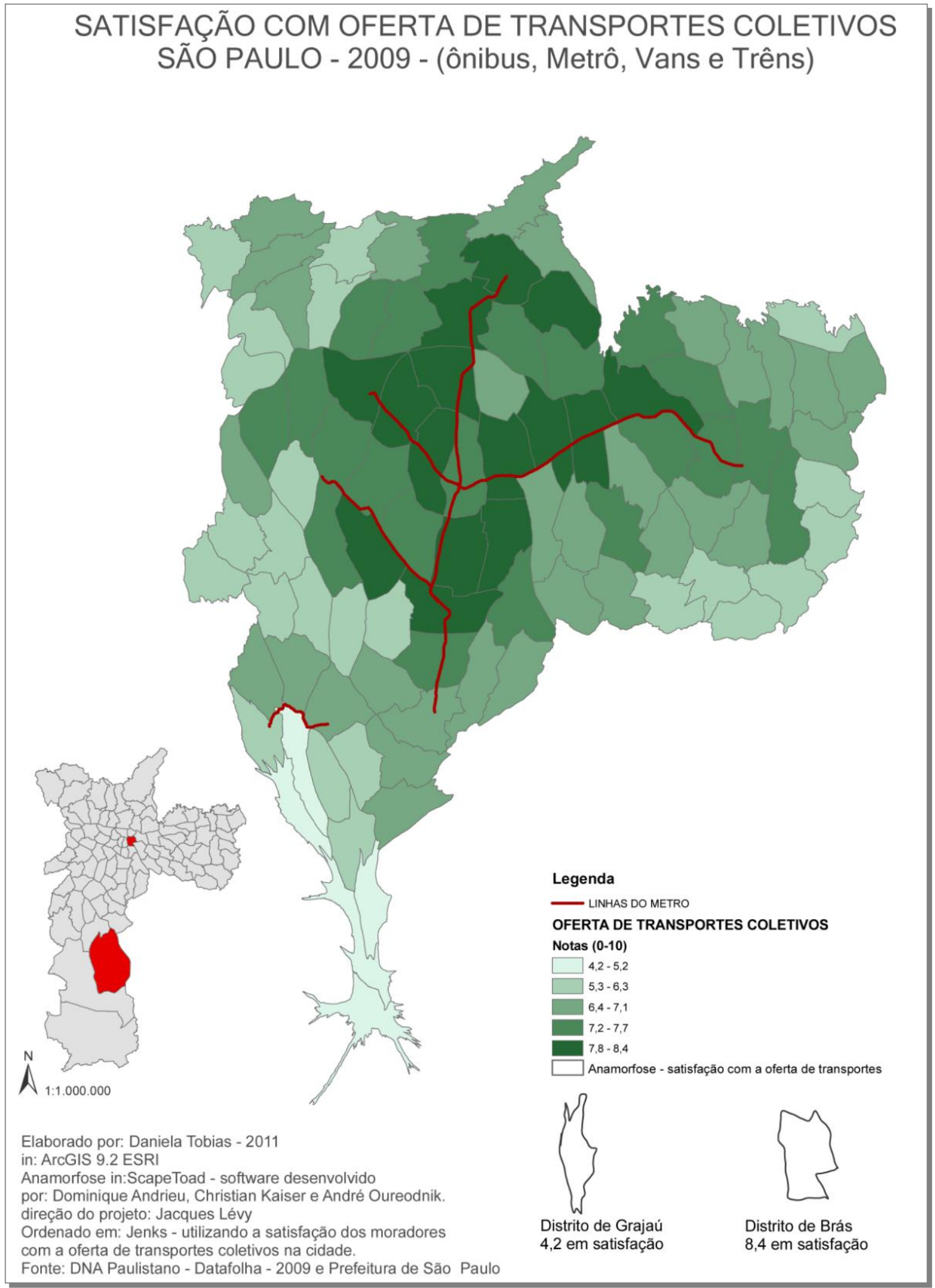

Mapa 8 - Satisfação com a Oferta de Transportes Coletivos - São Paulo 2009 (Ônibus, Metrô, Vans e Trens). 


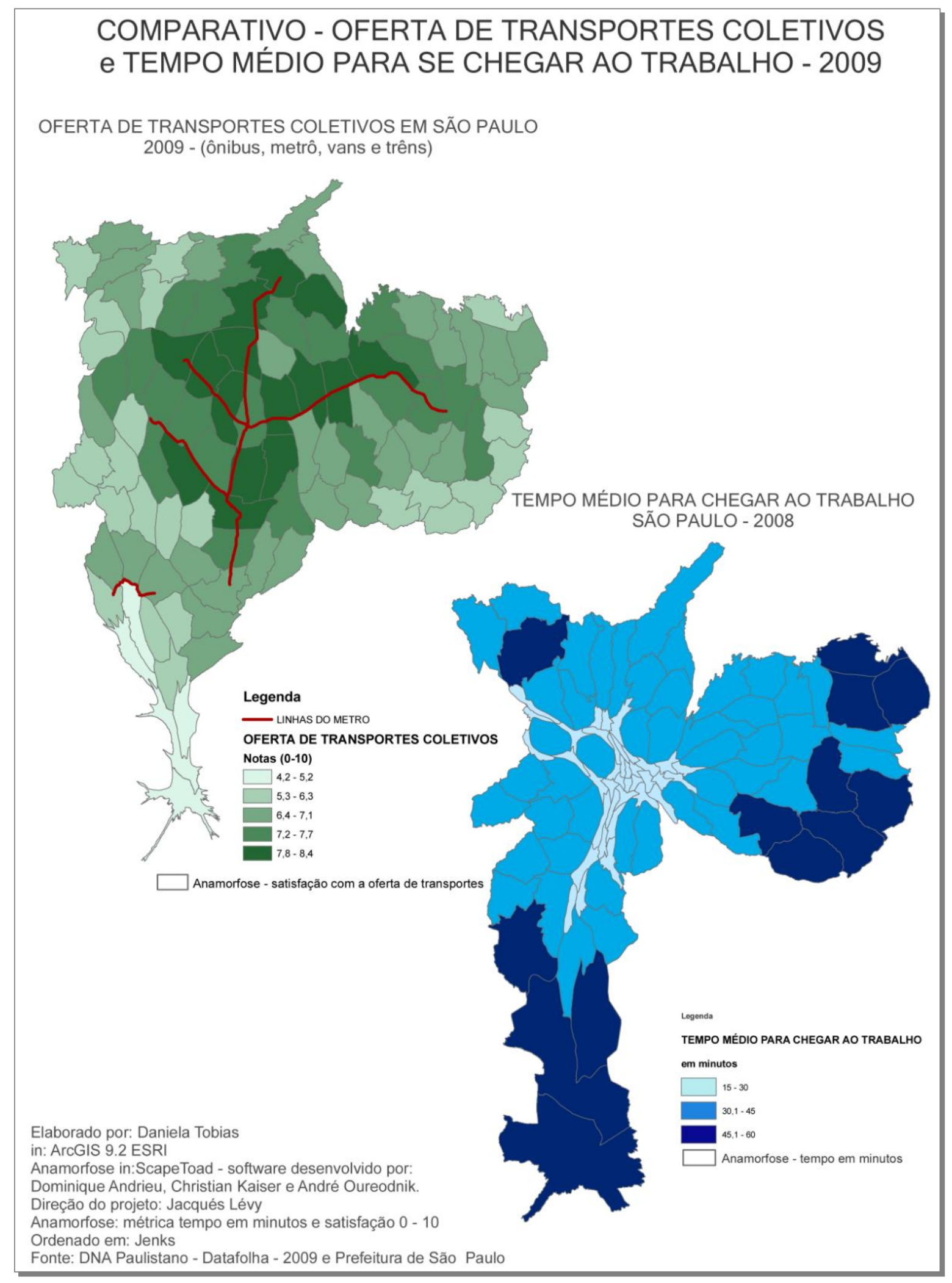

Mapa 9 - Comparativo entre os mapas de oferta de transportes público e Tempo médio para se chegar ao trabalho - São Paulo 2009 


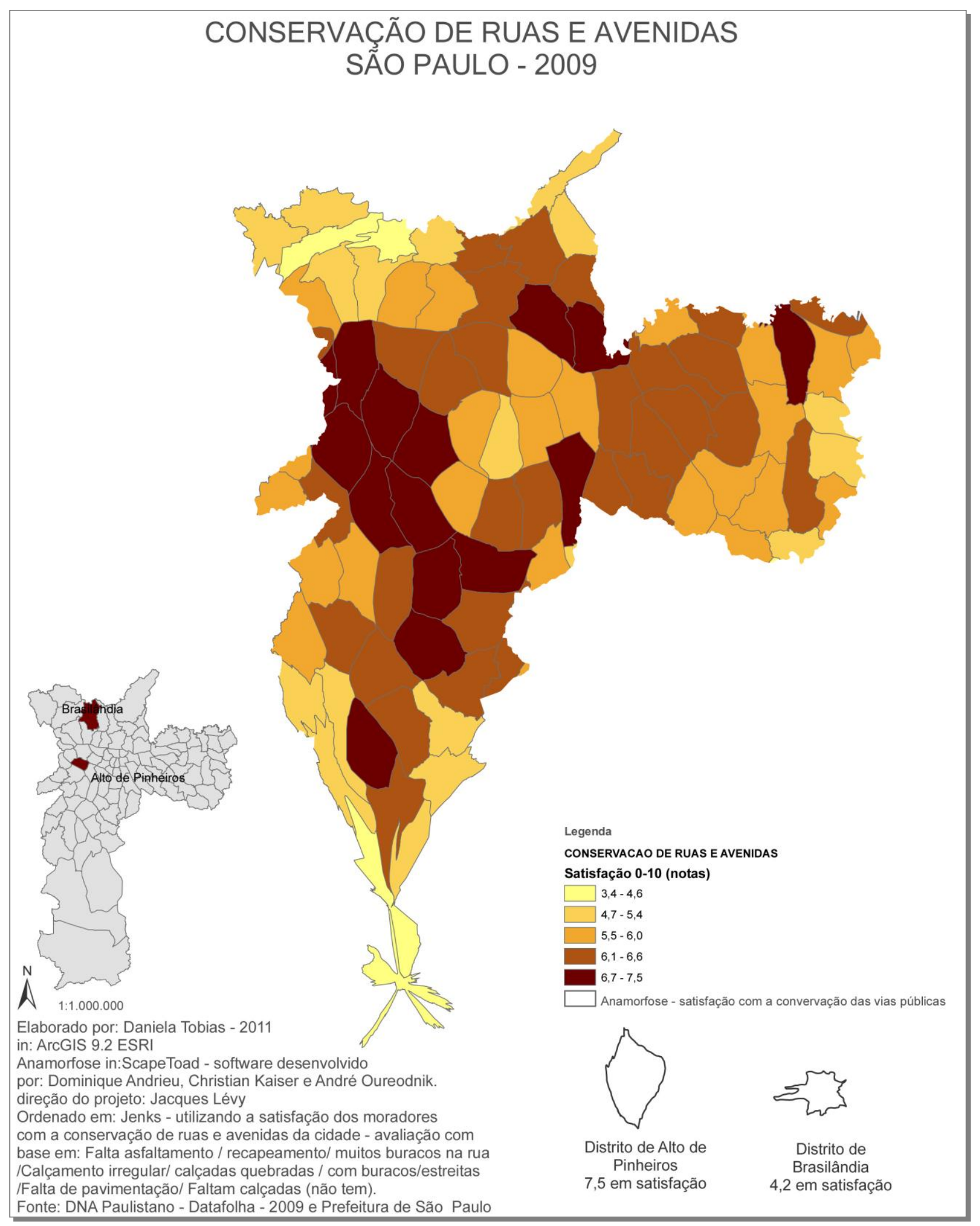

Mapa 10 - Conservação de Ruas e Avenidas - São Paulo 2009 


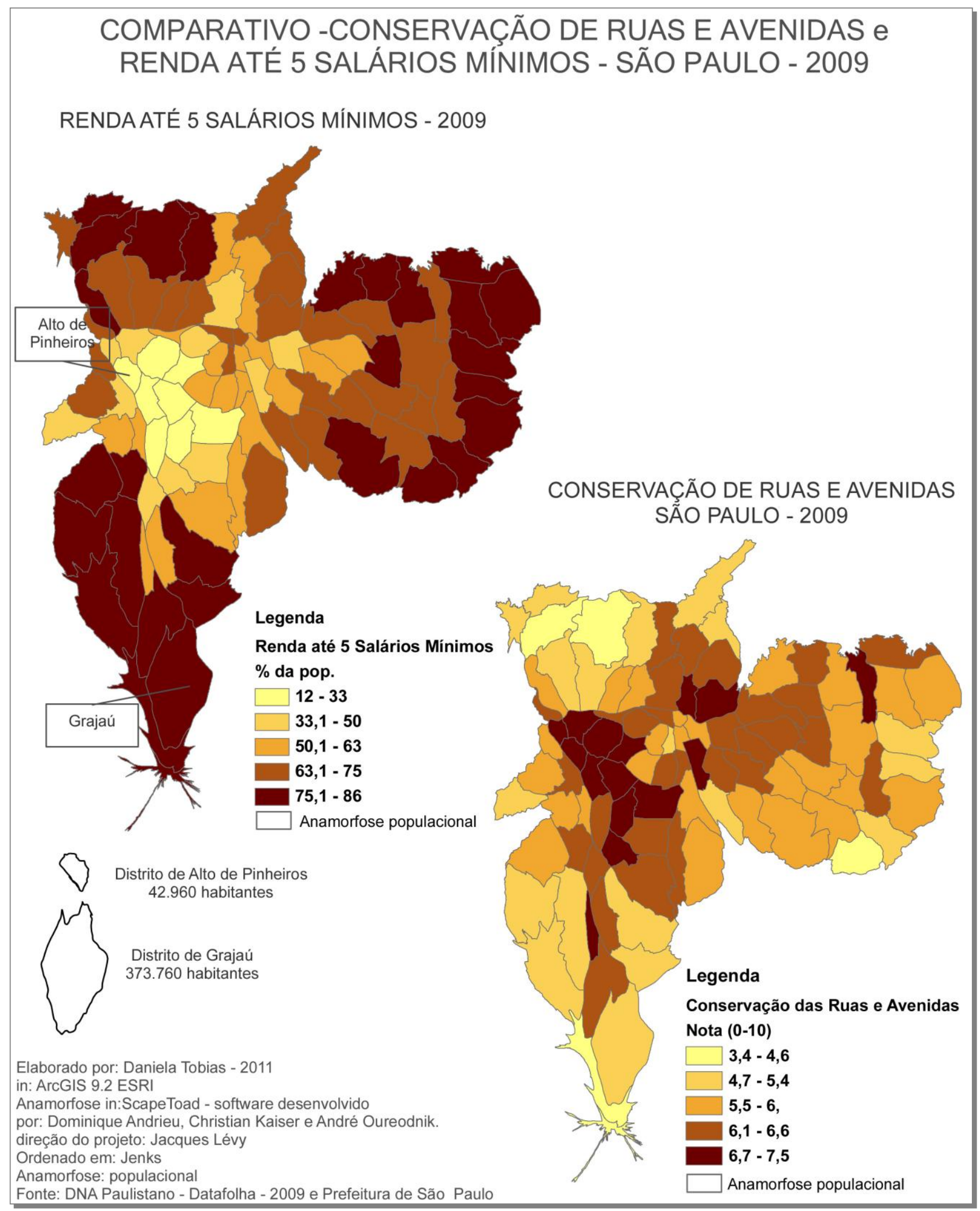

Mapa 11 - Renda até 5 Salários Mínimos e Conservação de Ruas e Avenidas São Paulo 2009 - Comparação com um Fundo Populacional 


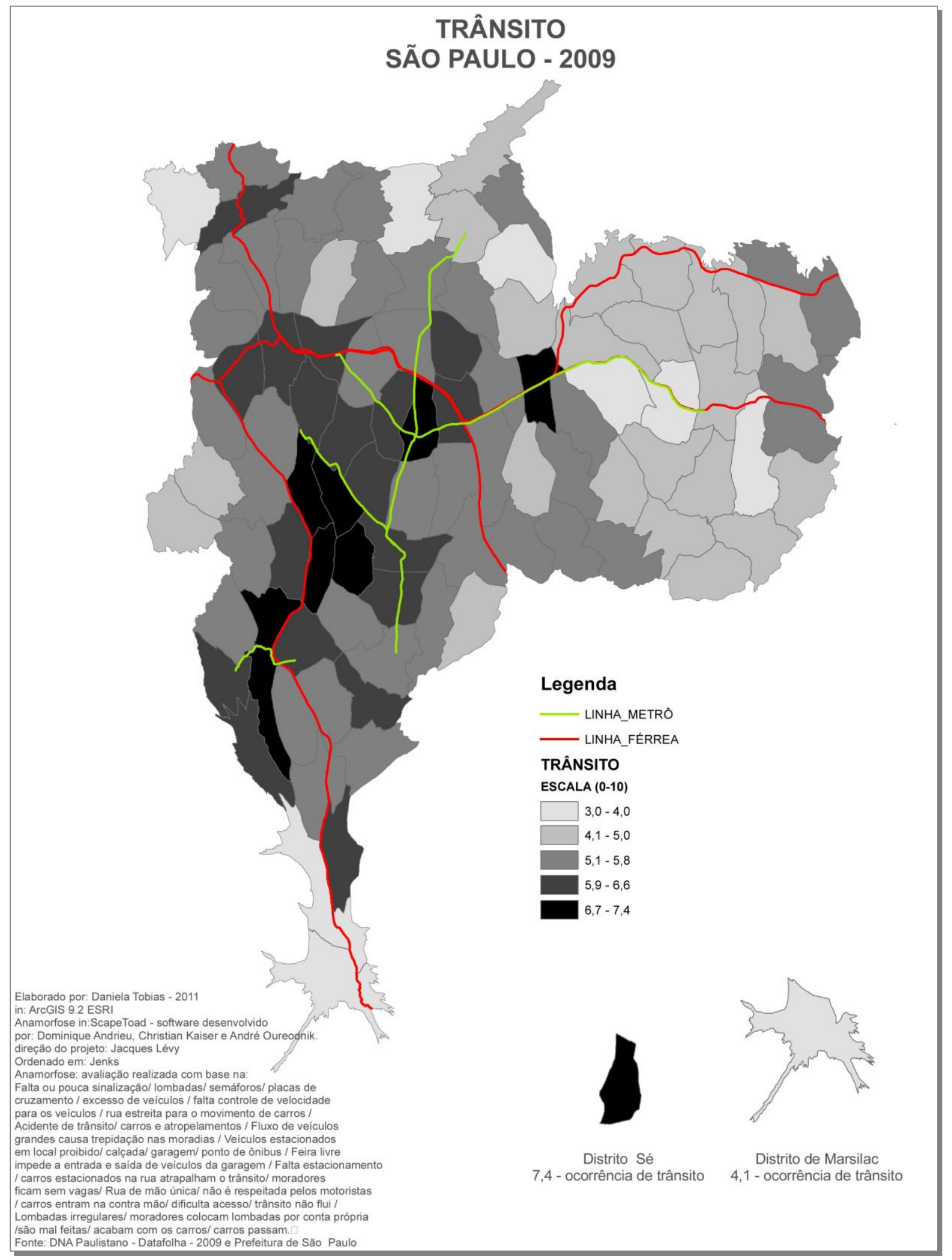

Mapa 12 -Trânsito - São Paulo 2009

Comparado com a oferta de transporte sobre trilhos 


\section{COMPARATIVO - TRÂNSITO e CONSERVAÇÃO DE RUAS E AVENIDAS - 2009}

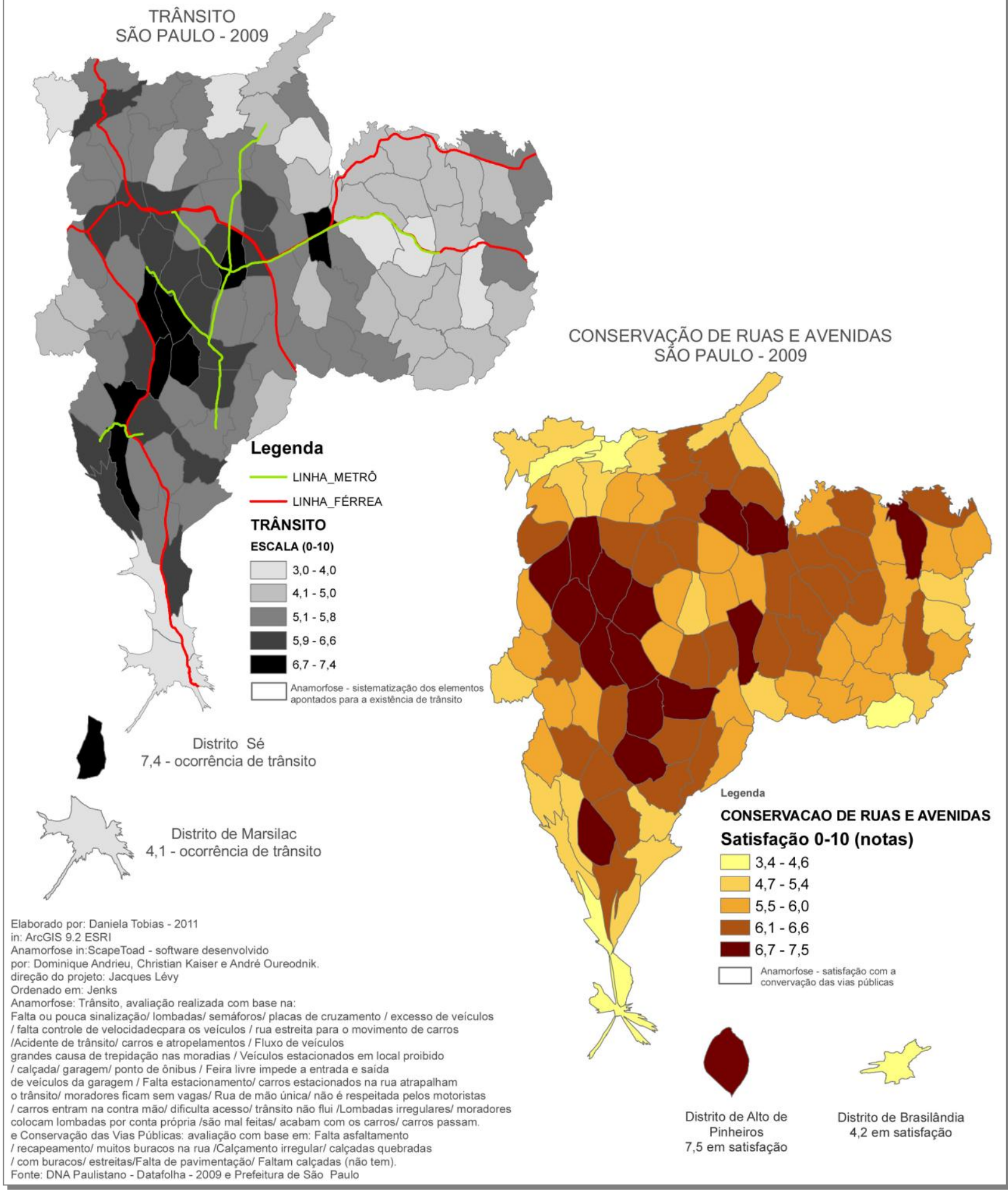

Mapa 13 - Comparativo entre Ocorrência de trânsito e Conservação de ruas e avenidas - São Paulo 2009 
Nesta mesma análise, sobre a mobilidade física na cidade de São Paulo, percebemos que podemos começar a inferir que, uma região da cidade começa a aparecer como uma região de "destaque", uma área mais evidenciada pelos índices de mobilidade sociais. Vemos isso através da geografia dos fenômenos mapeados.

Começa-nos aparecer, também, a relação triangular da mobilidade como possibilidade, que Jacques Lévy estabeleceu entre "o desejado, o possível e o realizado" (LEVY, 2000, p. 4).

Mesmo que o desejado possa ser a ocorrência de uma maior ou mais extensa mobilidade cotidiana em São Paulo, vemos que a oferta a essa possibilidade é cerceada pelos transportes e acessos existentes na cidade.

Vemos que muito mais do que o desejado apresenta-se o realizado, como imperativo do mercado, onde a oferta de trabalho, em comércios e serviços, concentrada nos distritos centrais (mapa 14), obriga que haja esse deslocamento diário na cidade e que contribua ainda mais a manutenção desse sistema gerador de transtornos à mobilidade. No (mapa 14) é usado um fundo de mapa em anamorfose representando a distribuição da quantidade da população por distrito e verificamos que a oferta de trabalho em comércio e serviços, não atende a lógica de distribuição populacional. Não gerando diversidade de atividades nos distritos mais afastados, será então uma prática anti-cidade, criando as conhecidas "regiões dormitórios" (lugares de residência vividos pelos trabalhadores apenas para sua prática de repouso, em virtude da baixa oferta de diversidade de atividades dessas regiões, obrigando-os a um maior deslocamento diário).

Ao tratar os deslocamentos não somente para a realização de trabalho, mas também para a prática de lazer, podemos apreender dinâmicas diversas. São Paulo possui hoje, segundo informações da prefeitura de São Paulo, 72 Shopping centers e sua distribuição acompanha a mesma lógica de adensamento das demais apresentadas até o momento: maior ofertas de diversidade de atividades aonde já existem (mapa 15). Tal afirmação é verificada, por exemplo, com a tendência de oferta de salas de cinema apenas dentro dos Shoppings ${ }^{13}$. Temos em São Paulo 134 salas de cinemas

\footnotetext{
${ }^{13}$ E lamentamos com tristeza o recente fechamento do cine Belas Artes.
} 
distribuídas pelos Shoppings paulistanos (mapa 16) o que faz com que mais essa procura de lazer ocupe os mesmos espaços, nas regiões centrais da capital.

As salas de teatro, shows e concertos que foram representadas no (mapa 17) também ficam concentradas nas regiões centrais, levando em conta que foram mapeadas as salas municipais, estaduais e particulares.

A questão do acesso ao lazer confinado aos Shoppings centers e suas salas de cinema por si só são práticas excludentes e limitantes, mesmo levando em consideração os shoppings tidos como "populares". Há também os danos econômicos e sociais que eles conseguem causar ao seu entorno próximo e mesmo distante. O seu acesso é muitas vezes calculado para atender a uma determinada camada da sociedade, alvo de sua natureza comercial. É limitante inclusive em sua possibilidade de acesso, pois não aceita em sua proximidade a existência de pontos de ônibus. Alguns como o Shopping Vila Lobos e Cidade Jardim, nem mesmo possuem uma oferta razoável de linhas de ônibus em suas regiões; apenas recebe clientes possuidores e usuários de automóveis.

"Toda vez que se vai de carro a um Shopping Center, contribui-se para o aumento dos preços da loja da esquina e até se acelera a sua falência" (MASSEY, 2000, p. 181).

Jane Jacobs diagnostica os fenômenos dos Shoppings centers e também os grandes Centros Culturais, como elementos causadores de exclusão nas cidades.

"Os Shoppings Centers monopolistas e os monumentais centros culturais, com 0 espalhafato das relações públicas, encobrem a exclusão do comércio - e também da cultura - da vida íntima e cotidiana das cidades". (JACOBS, 2000, p.2).

Está claro que todo citadino tem direito aos espaços públicos da cidade como seus centros culturais, bibliotecas e teatros, porém também observamos uma diferenciação de quais "culturas" são oferecidas as classes menos favorecidas e com menos mobilidade. No (mapa 17) temos essa concentração de espaços culturais condensados na área "de destaque", como observado até o momento, as áreas centrais. 
Porém não se trata aqui de uma questão única de condição de acesso físico, e sim de uma construção social, de divulgação às camadas populares e mesmo de incentivo a sua participação, como tem ocorrido com a "Virada Cultural" - Uma maratona de apresentações culturais em diversos pontos da cidade - organizada pela Prefeitura de São Paulo e que ganhou a participação da população, desejosa por atividades diversificadas, principalmente voltadas ao público mais jovem.

Estamos falando do acesso à informação, da necessidade de contatos virtuais capazes de gerarem encontros.

O contrário disso é o isolamento social, que embora possa vir acompanhado de projetos urbanos necessários à organização espacial urbana, não devem servir de instrumentos de imobilidade. Os espaços para a prática da cidade necessitam da diversidade de equipamentos sociais, como estes centros culturais e esportivos, (mapas 18 e 19).

O perigo de políticas públicas, mais voltadas à oferta de espaços locais de interação social, está na homogeneização destes espaços, minimizando as trocas culturais e não disponibilizando os outros espaços da cidade. Estes espaços públicos centralizados ou mesmo "monumentais", ficam menos públicos.

A busca, portanto, é de uma oferta de diversidade nos lugares, mas uma diversidade com mobilidade, uma diversidade que sirva de base à ampliação do acesso a novas mobilidades, novas trocas, novos contatos, à cidade como direito e opção.

Embora não tenhamos como objetivo a classificação da mobilidade por classes sociais, apresentamos uma frase aparentemente provocadora se buscarmos, viciosamente, justificar exclusivamente, a falta de mobilidade à falta de recursos, mas que acompanha uma lógica clara se nos desprendermos dessa tendência: "Em particular, é porque são pouco móveis que as populações mais despossuídas são despossuídas”. (LÉVY, 2000, p.4).

O que se torna explícito nas palavras de José de Souza Martins, explicando esse resultante apresentado por Lévy, da seguinte maneira:

"Ora, o direito justo dos pobres é o de terem acesso às promessas sociais e revolucionárias do centro, do monumento e do monumental, do teatro, da música 
erudita, da arte, dos museus, do propriamente urbano e do bem estar que ele anuncia e possibilita - aquilo que é propriamente emancipador do homem. A falta de acesso corrói o referencial crítico que possibilitaria a um periférico fazer a crítica social e política do seu periferismo". (MARTINS, 2001, p.81). 


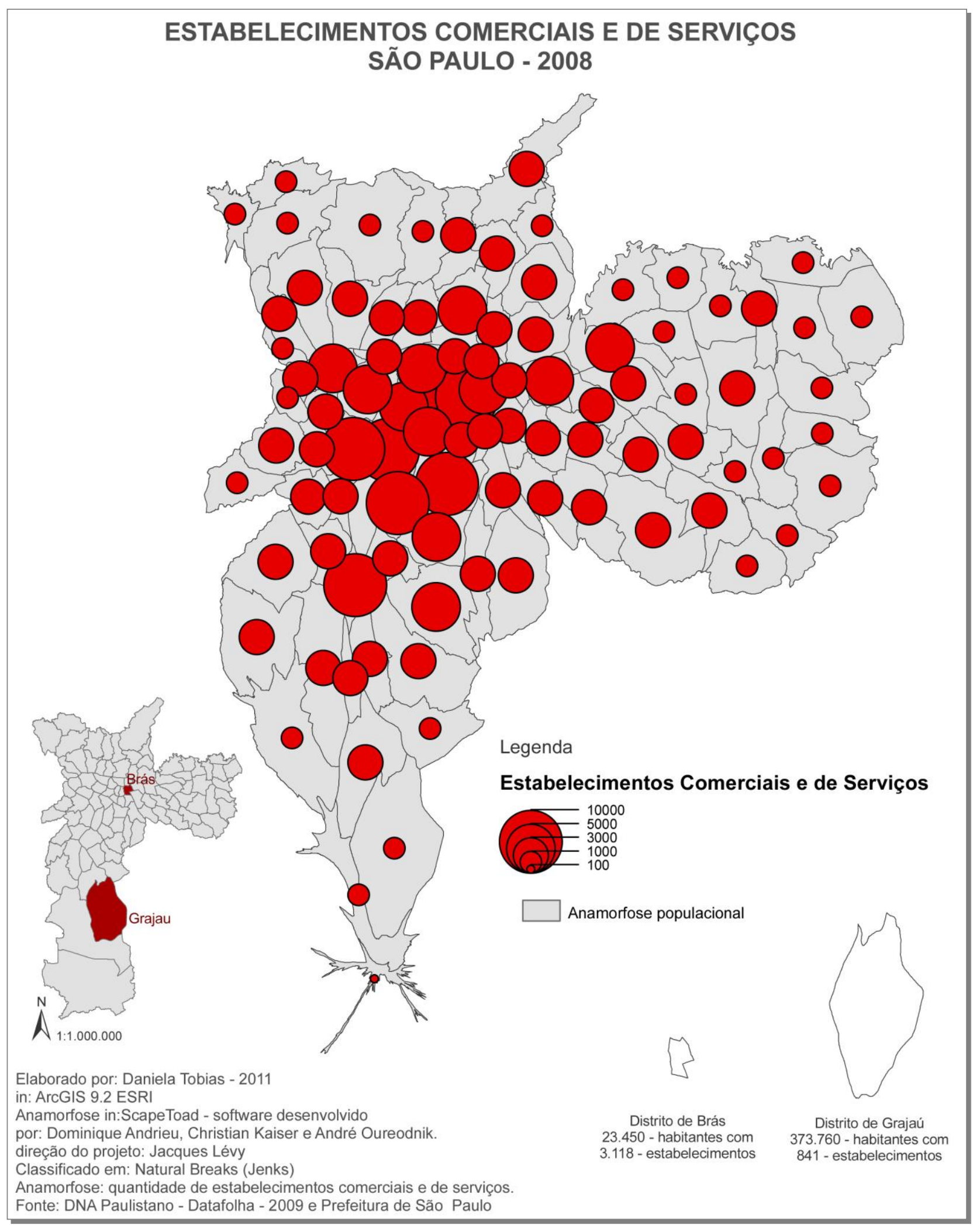

Mapa 14 - Estabelecimentos comerciais e de serviços - São Paulo 2008 


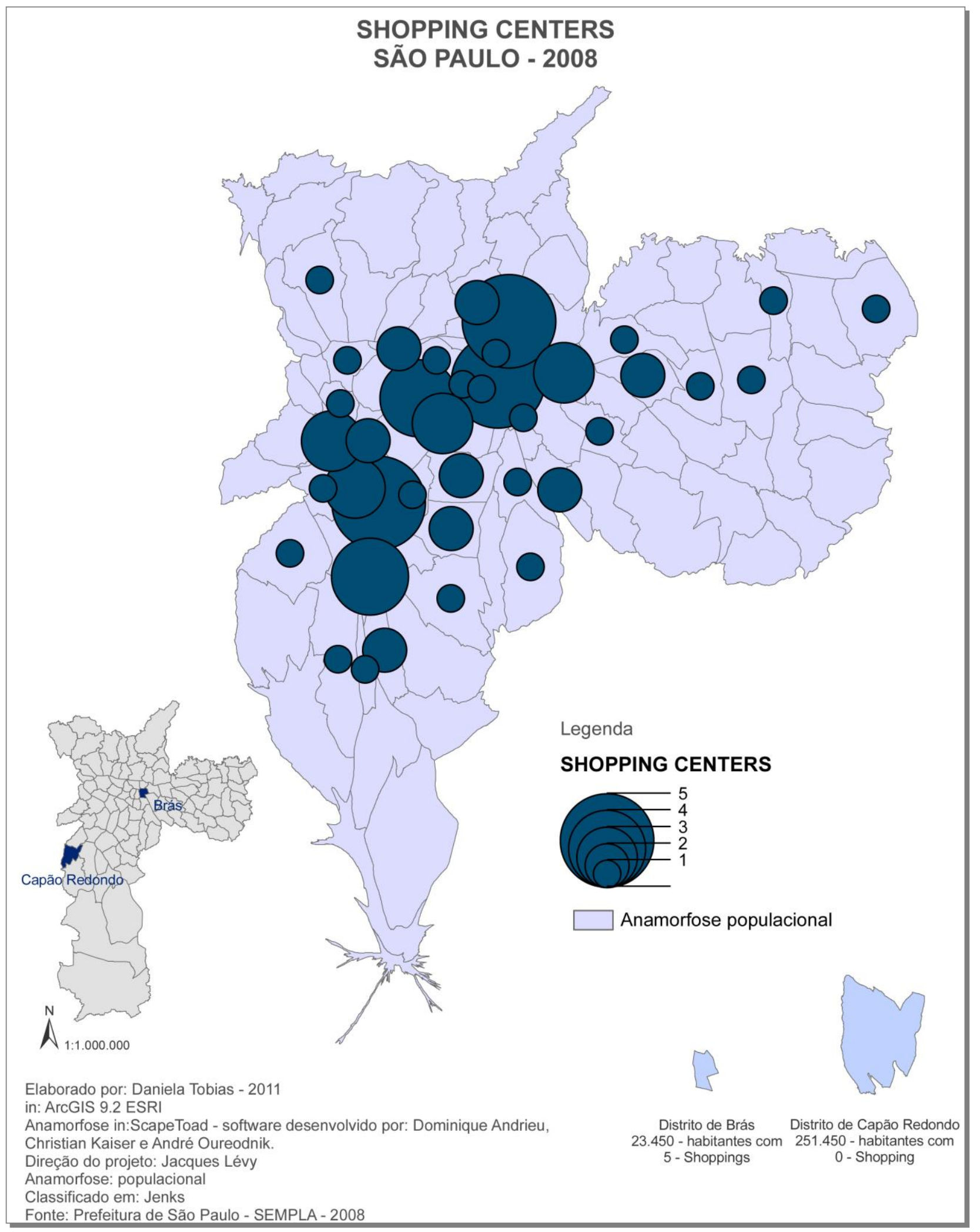

Mapa 15 - Shopping centers - São Paulo 2008 


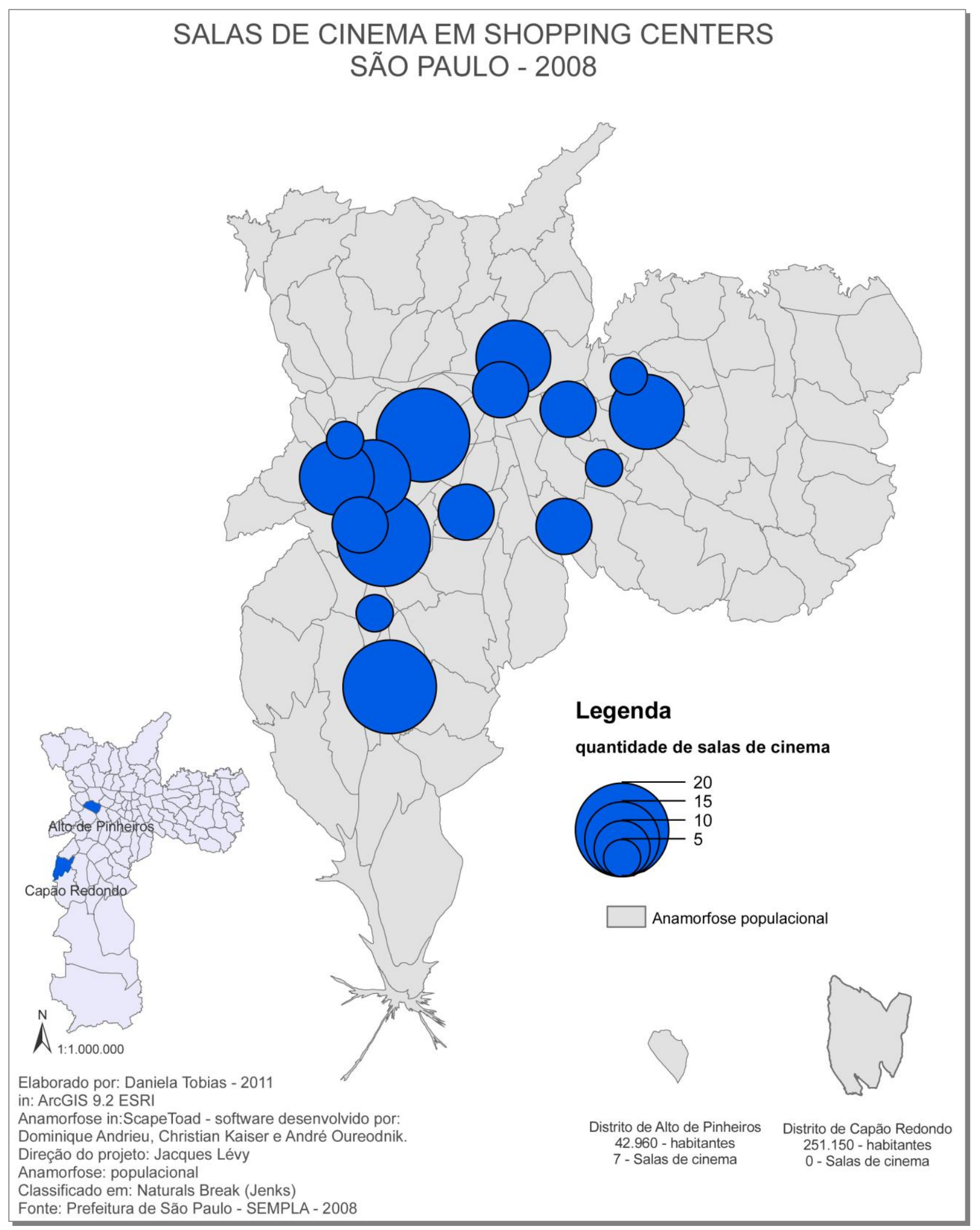

Mapa 16 - Salas de cinema em shopping centers

São Paulo 2008 


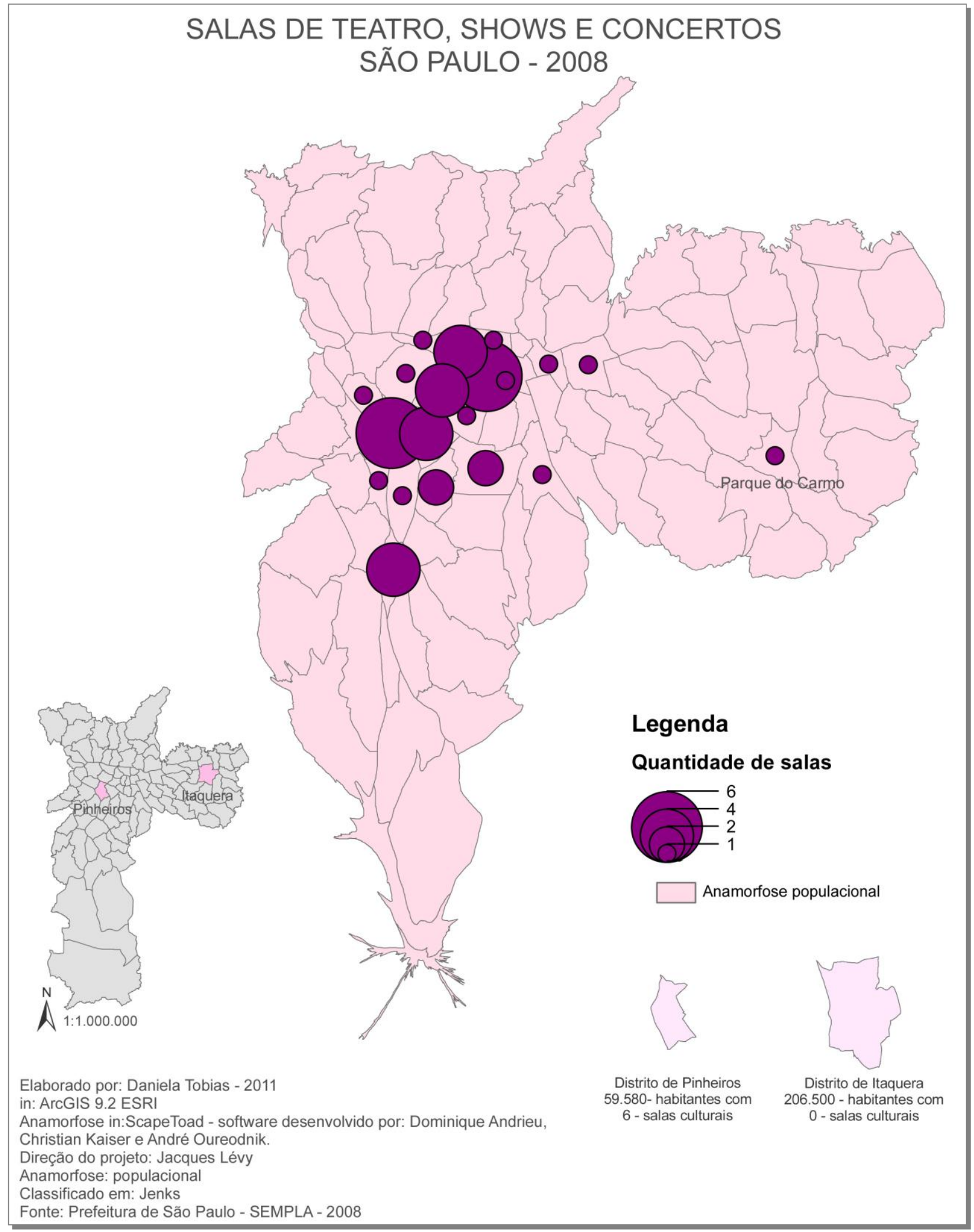

Mapa 17 - Salas de teatro, shows e concertos

São Paulo 2008 


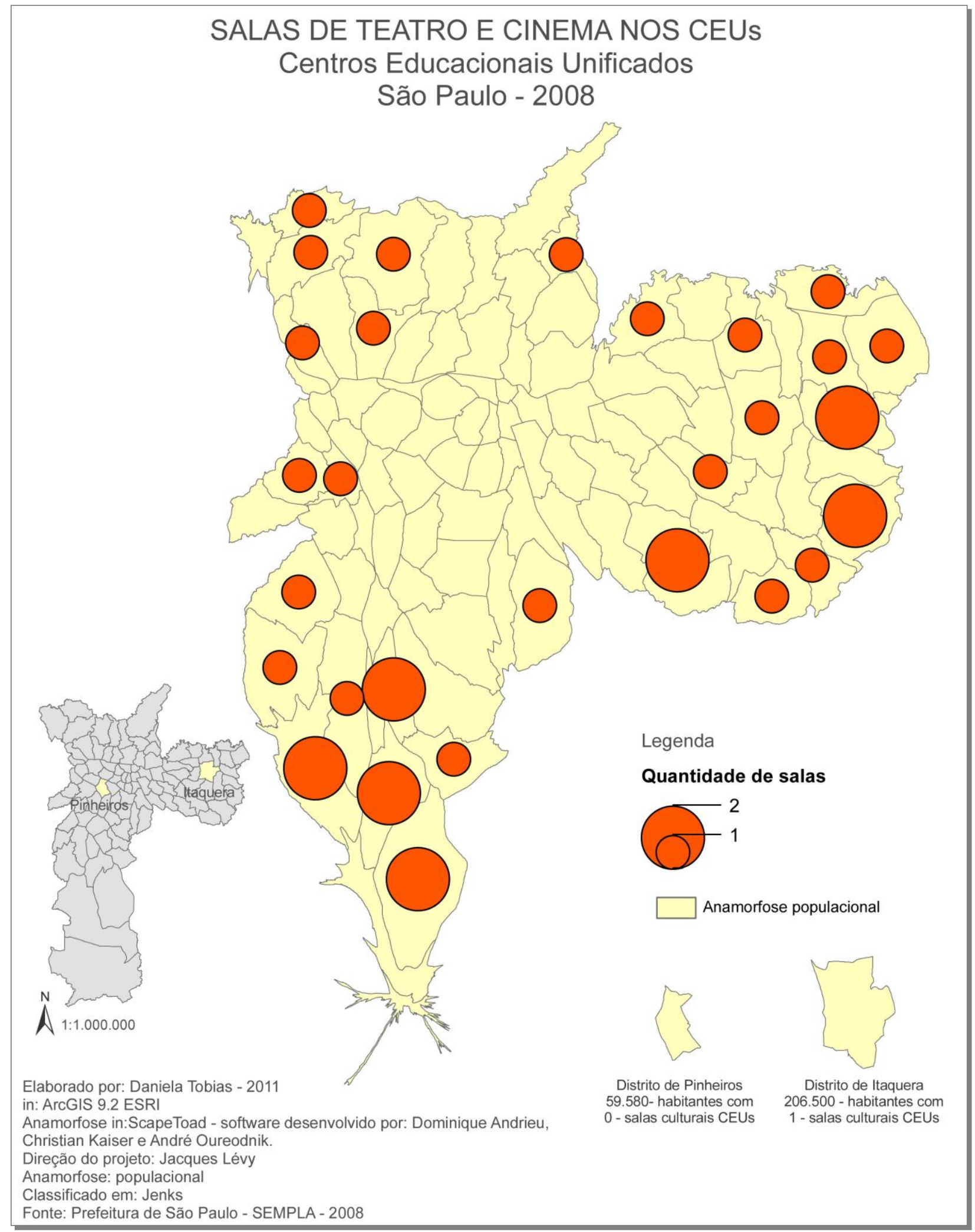

Mapa 18 - Salas de teatro e cinema nos CEUs São Paulo 2008 


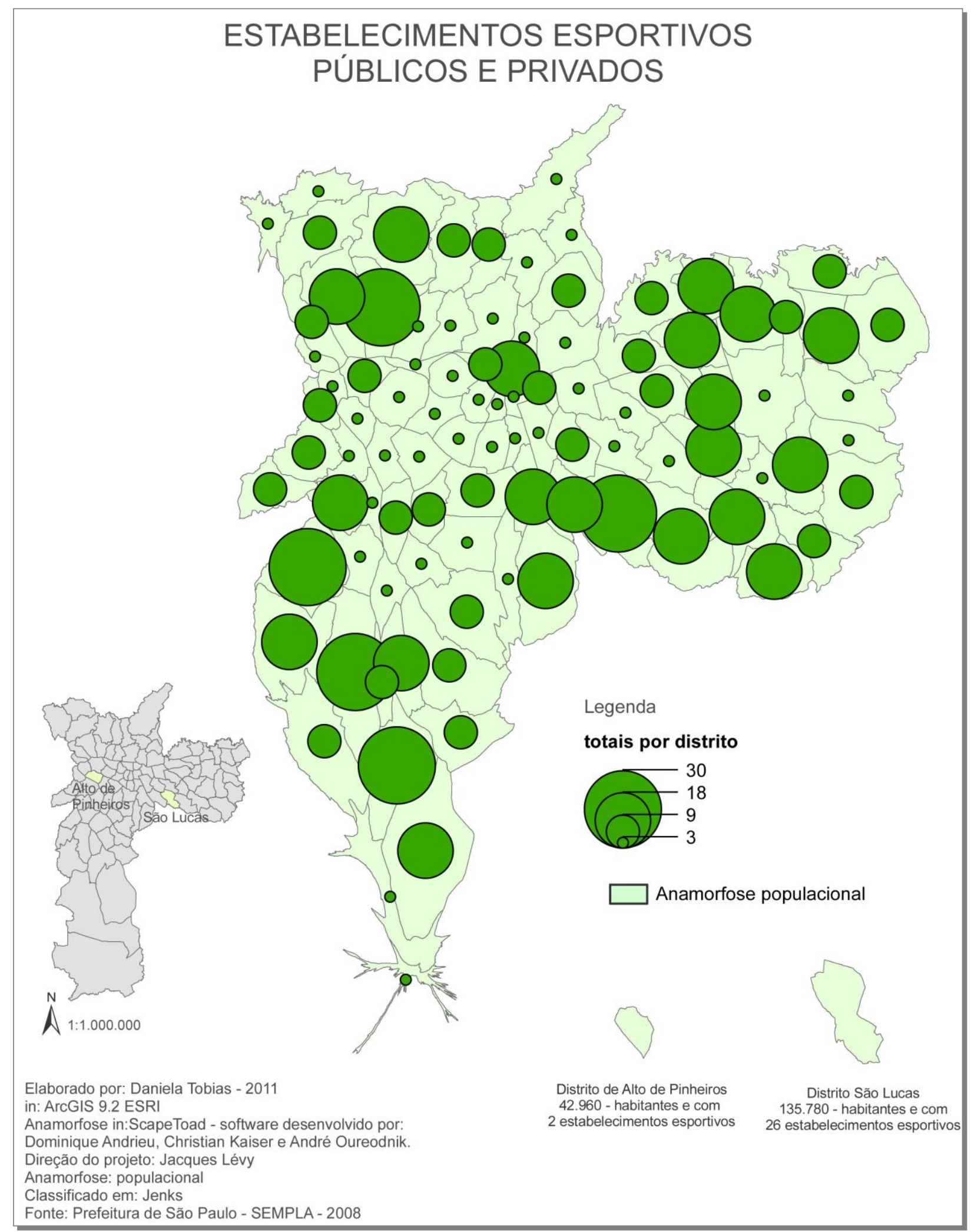

Mapa 19 - Estabelecimentos esportivos públicos e privados

São Paulo 2008 


\section{1.b - A mobilidade virtual paulistana}

Ao trabalharmos as variáveis de mobilidade física, mesmo que usemos diversas métricas como, pedestre, tempo, custo entre outras, ainda assim estaremos falando de uma mobilidade de acesso específico, em rede, de um ponto a outro, circunscritos em um limite espacial possuidor de fronteiras urbanas.

Agora, ao analisarmos a mobilidade virtual, quebramos estes limites espaciais e multiplicamos a nossa escala de estudo, ainda que, mensurando alguns de seus objetos de mobilidade, o seu alcance se torna ilimitado. 0 espaço virtual hoje, se funde ao espaço mundial e mesmo não pretendendo explicar o todo mundial apenas pelo estudo de uma parte, o local, analisamos esse local para verificarmos como ele está inserido neste espaço maior e o quanto ele é, ou possui a possibilidade de ser, influenciado por esse espaço mundial.

\footnotetext{
"A instantaneidade da informação globalizada aproxima os lugares, torna possível uma tomada de conhecimento imediata de acontecimentos simultâneos e cria entre lugares e acontecimentos uma relação unitária na escala do mundo". (SANTOS, 1998, p. 49).
}

Pensarmos o acesso a esse espaço mundial inserido nas práticas cotidianas da cidade cria uma sensação de alucinação virtual do estar sem coabitar, da necessidade de uma organização deste espaço para a possibilidade de seu acesso, acesso este que embora não fuja, mesmo que virtualmente das lógicas de mercado, é capaz de proporcionar maior mobilidade aos cidadãos.

Ao analisarmos os (mapas 20, 21 e 22), respectivamente - distribuição dos telefones fixos por distrito, frequência e acesso a internet e posse de TVs por assinatura; vemos uma distribuição desigual nos distritos da cidade, e enfatizamos que essa distribuição não está isenta de comparações à mobilidade física, e maior ainda se comparada ao (mapa da renda acima de cinco salários mínimos).

Vemos que a lógica desse mercado de acessibilidade virtual, do acesso a comunicação, informação e participação no espaço mundo, se comporta de maneira excludente em sua prática e fragmentado em suas feições espaciais. 
Embora estejamos analisando a cidade de São Paulo, possuidora da maior infraestrutura tecnológica do país e detentora de um maior número de empresas de comunicação e informação, vemos que ela reage de forma pulverizada a essa condição de possibilidade de acesso virtual. Não por falta de intenções de oferta, mas também, por falta de manutenção desse direito ao espaço.

Recentemente ao participar de um encontro dos professores da rede estadual de educação do Estado de São Paulo com o secretário da educação senhor Herman Voorwald ouvimos dele que, o mesmo entende a necessidade do funcionamento das salas do "Acessa Escola", um programa que oferta aos alunos à possibilidade de acesso virtual a rede Web. Porém ele complementa que em todas as escolas por ele visitadas, as salas do Acessa estavam fechadas, por problemas técnicos (principalmente quanto à oferta de sinal) que geravam incapacidade de acesso.

Estas formas de acesso ao espaço virtual, de possibilidade de uma mobilidade rica em prover informação, comunicação e conhecimento é um fato.

A possibilidade de transformação direta dessas mobilidades virtuais em reais, físicas, também é fato.

Contudo também é fato a existência da possibilidade de isolamento do espaço virtual, mesmo em nosso tempo histórico-geográfico.

\footnotetext{
“... num mundo em que a modernidade se tornou irrecusável; mas a dosagem de sua combinação, não mais a partir dos imperativos da técnica, de que a economia se tornou subordinada, mas a partir dos valores, o que ensejaria uma nova forma de pensar um porvir onde o social deixaria de ser residual e à economia e à tecnologia seria atribuído um papel histórico subordinado, em benefício do maior número" (SANTOS, 1998, p. 158).
}

O acesso à informação, muitas vezes subordinadas a TV faz com que exista uma ordem cultural, que levaria a uma ordem comercial e que levaria a uma prática social - mesmo que tênue e passageira. E essa prática também estaria estratificada de acordo com a capacidade de acesso a essa informação, que pode ser diferenciada em virtude da possibilidade de aquisição de canais de TV por assinatura. Em certo momento esse diferencial de acesso a 
informação caracterizaria uma diversidade de comportamento urbano e prática da cidade. 


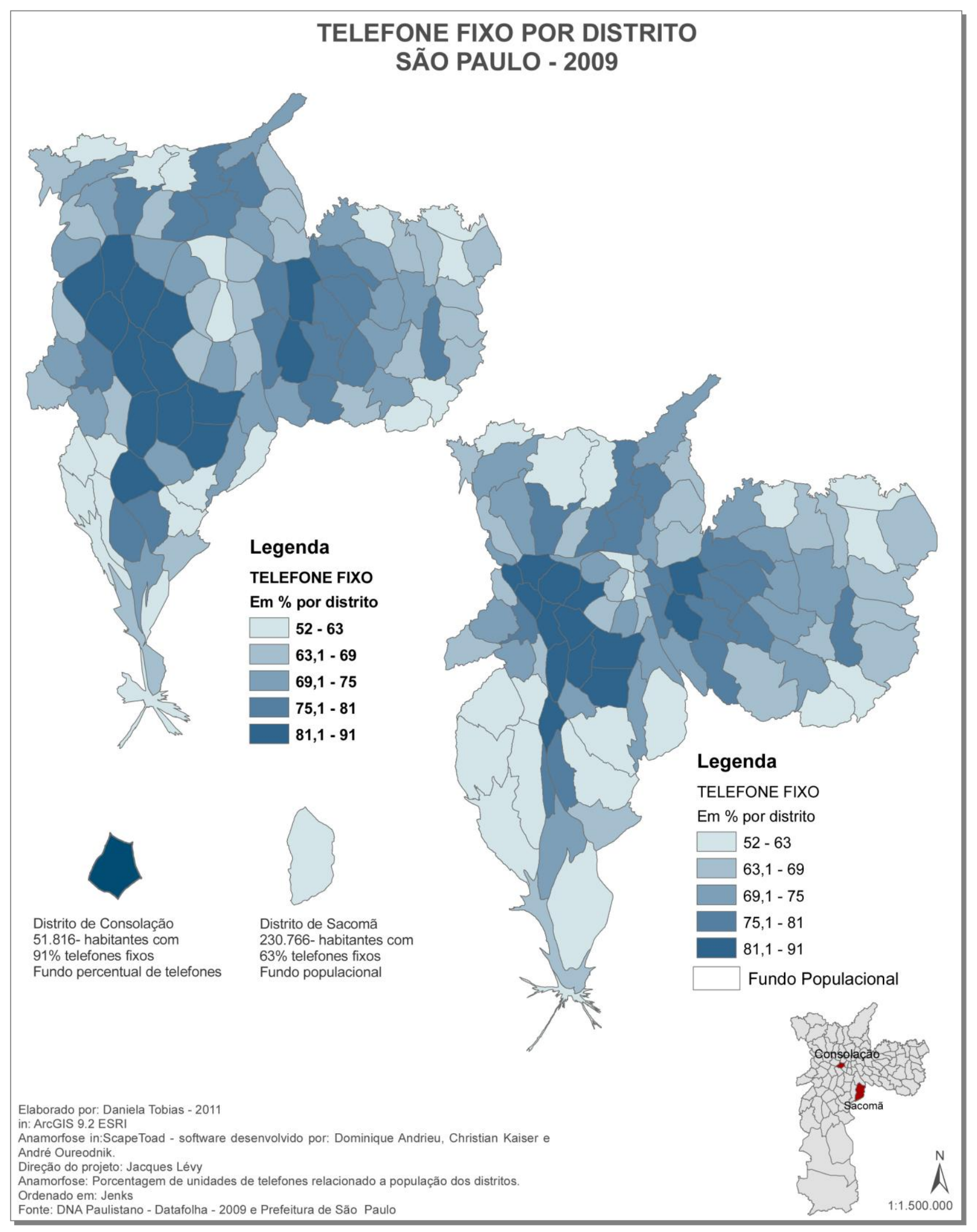

Mapa 20 - Telefone fixo por distrito - São Paulo 2009 


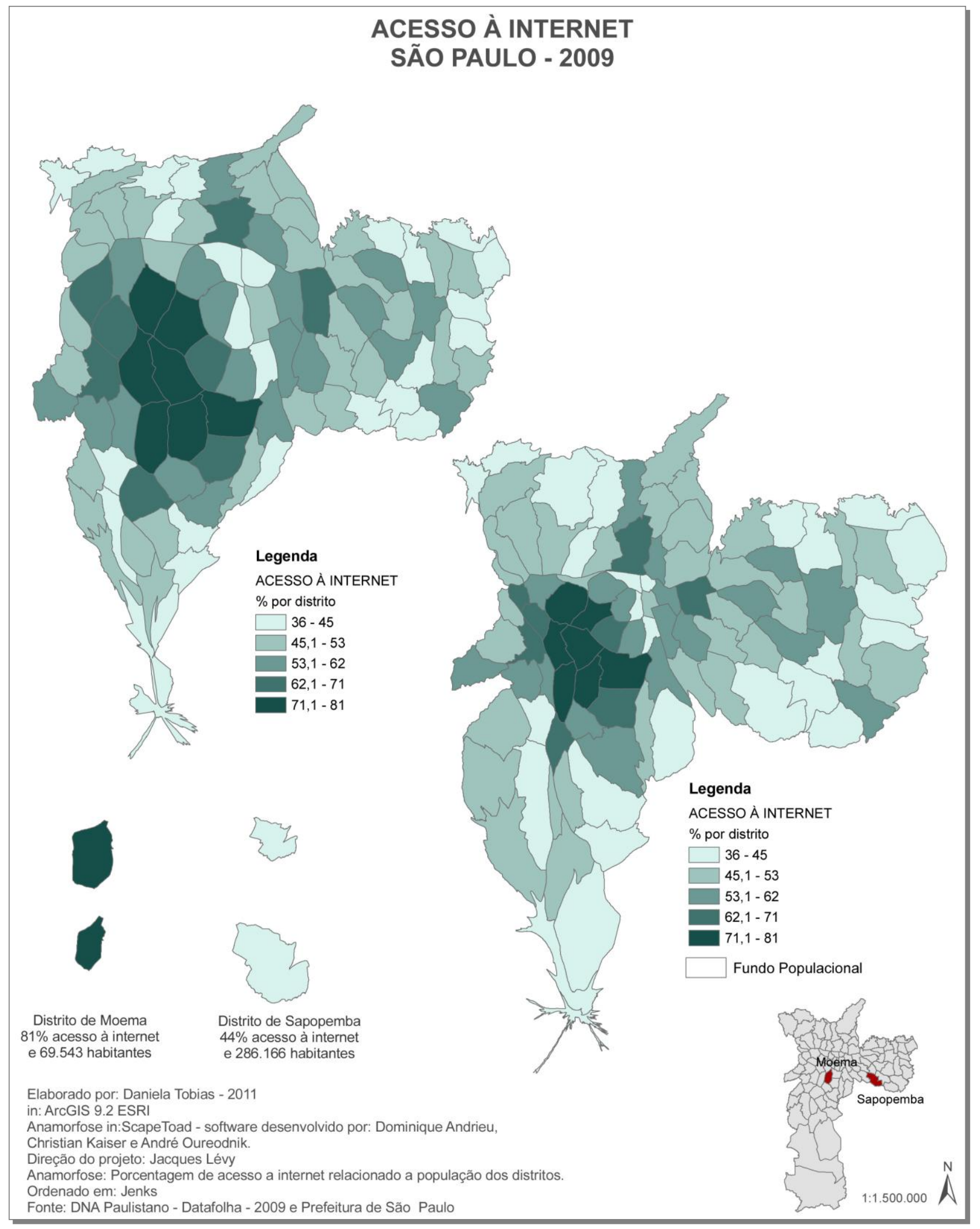

Mapa 21 - Acesso a internet - São Paulo 2009 


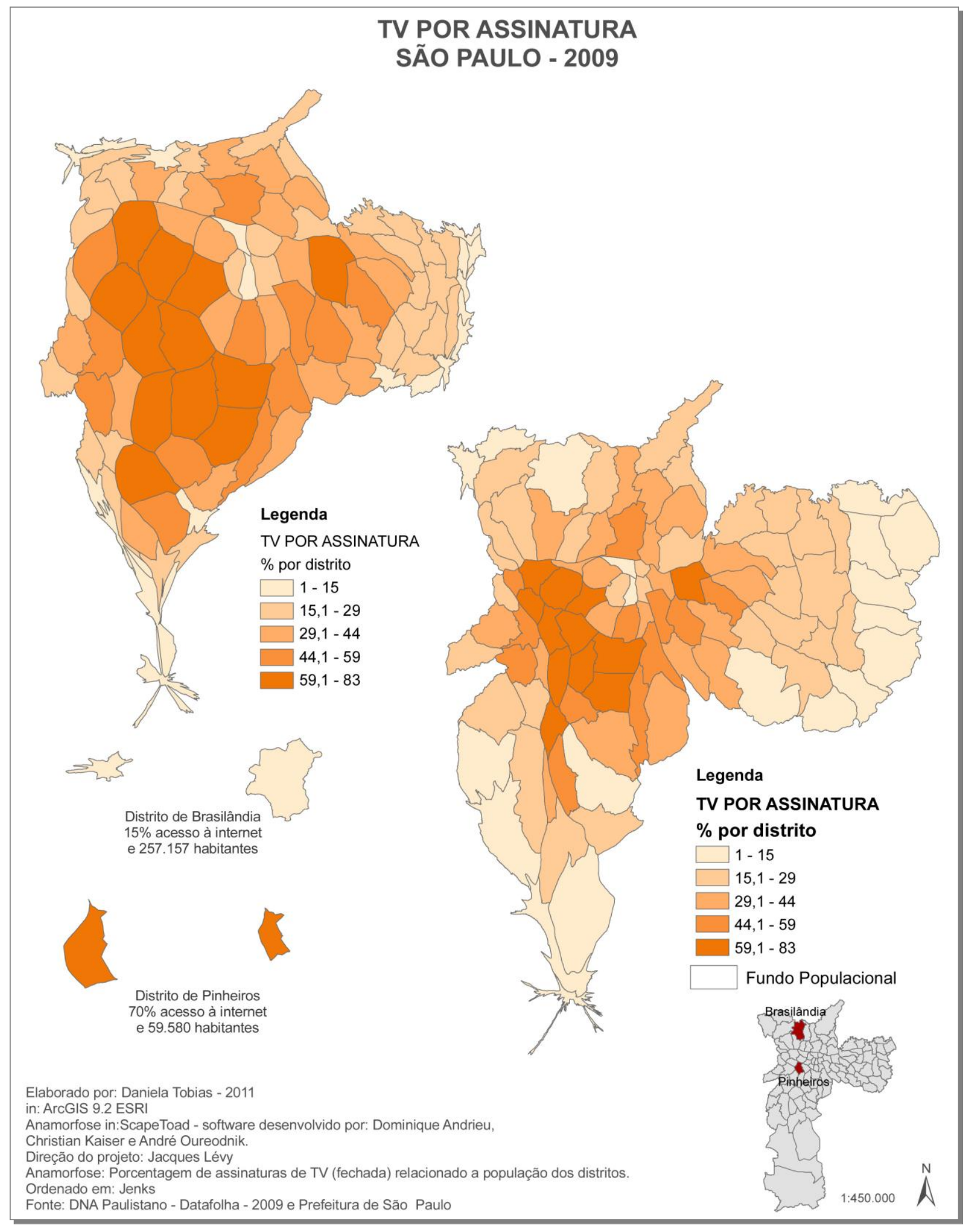

Mapa 22 - TV por assinatura - São Paulo 2009 


\subsection{Os componentes do lugar}

Em uma análise das feições apresentadas pela cidade através de seus sistemas de funcionamento, buscamos mostrar a cidade e as contradições em seus funcionamentos condicionados a uma relação de construção e também de gestão, distrital através das subprefeituras e; governamental em outras instâncias políticas de ação direta na cidade.

Dentre os elementos de análise do espaço de vivência dos cidadãos urbanos necessitamos explanar que ele pode ser o lugar de execução de suas atividades cotidianas, como trabalho, estudo e lazer, já que é provável que a maioria da população passe a maior parte de seu tempo em lugares alheios a suas residências. Porém trabalhamos principalmente com o espaço das residências, dados relacionados ao espaço do viver e não da produção, visto que este é o considerado pelos moradores da cidade o "seu" espaço, seu lugar de afinidade e onde são estabelecidas as suas relações de convivência.

Yi-Fu Tuan $(2005$, p.9) ao se referir a certas espécies que defendem seus territórios salienta que elas se comportam como pensam a respeito de certas áreas delimitadas como sua propriedade. $O$ autor também afirma que transformamos as localizações em lugares ao the atribuirmos valores humanos, ligação emocional aos objetos físicos, as funções dos conceitos e símbolos na criação da identidade do lugar.

É evidente que a forma de interação da população com a cidade não é, e nem pode ser, dissociada da conformação estrutural do seu espaço. As formas de interagir com o lugar estão condicionadas à oferta dos diversos equipamentos urbanos a esta população.

Nossas fontes buscam, embora de forma distante, incluir o citadino como ator das análises críticas sobre o seu espaço.

"Raramente se pergunta aos moradores e usuários dos espaços afetados o que pensam de tais intervenções e, quando isso acontece, fica-se apenas na consulta, sem que se dê às pessoas a oportunidade de participar, verdadeiramente, na busca de soluções para o problema de seus bairros e suas cidades. Para nós 0 ato (o processo) de se planejar uma cidade deve ser algo essencialmente distinto: os próprios cidadãos devem poder decidir sobre os destinos dos espaços em que 
vivem, por meio de debates livres abertos $\mathrm{e}$ transparentes". (SOUZA e RODRIGUES, 2004, p.14)

O caráter imediatista das diversas formas de gestão, na busca de solução dos problemas urbanos, produz de forma ideológica na cidade uma visão da necessidade de sempre minimizar problemas e raramente além, por meio de processos que objetivam mais a gestão e pouco o planejamento. Não buscar as sugestões e contribuições na população dos lugares inibe as novas ideias de melhorias e bem estar, deixando que a cidade de São Paulo tenha seu ritmo de crescimento ou de remodelagem, ditado muito mais por forças externas a esse espaço, do que pelos seus maiores investidores, a população paulistana.

"Diferentemente do planejamento, a gestão é uma atividade que remete ao presente, ao aqui e agora [...] Podemos ver o planejamento como a preparação de uma gestão futura". (SOUZA e RODRIGUES, 2004, p.16 e 17)

Como podemos ver nas análises cartográficas deste capítulo, o planejamento é emergencial em uma cidade, tão desigual, como São Paulo, que cresce e se organiza com grande velocidade de tempo e que não consegue equalizar as suas ofertas de equipamentos urbanos, básicos e necessários ao bem estar da população.

"A cidade, onde tantas necessidades emergentes não podem ter resposta, está desse modo fadada a ser tanto o teatro de conflitos crescentes como o lugar geográfico e político da possibilidade de soluções". (SANTOS, 2001, p.11) 


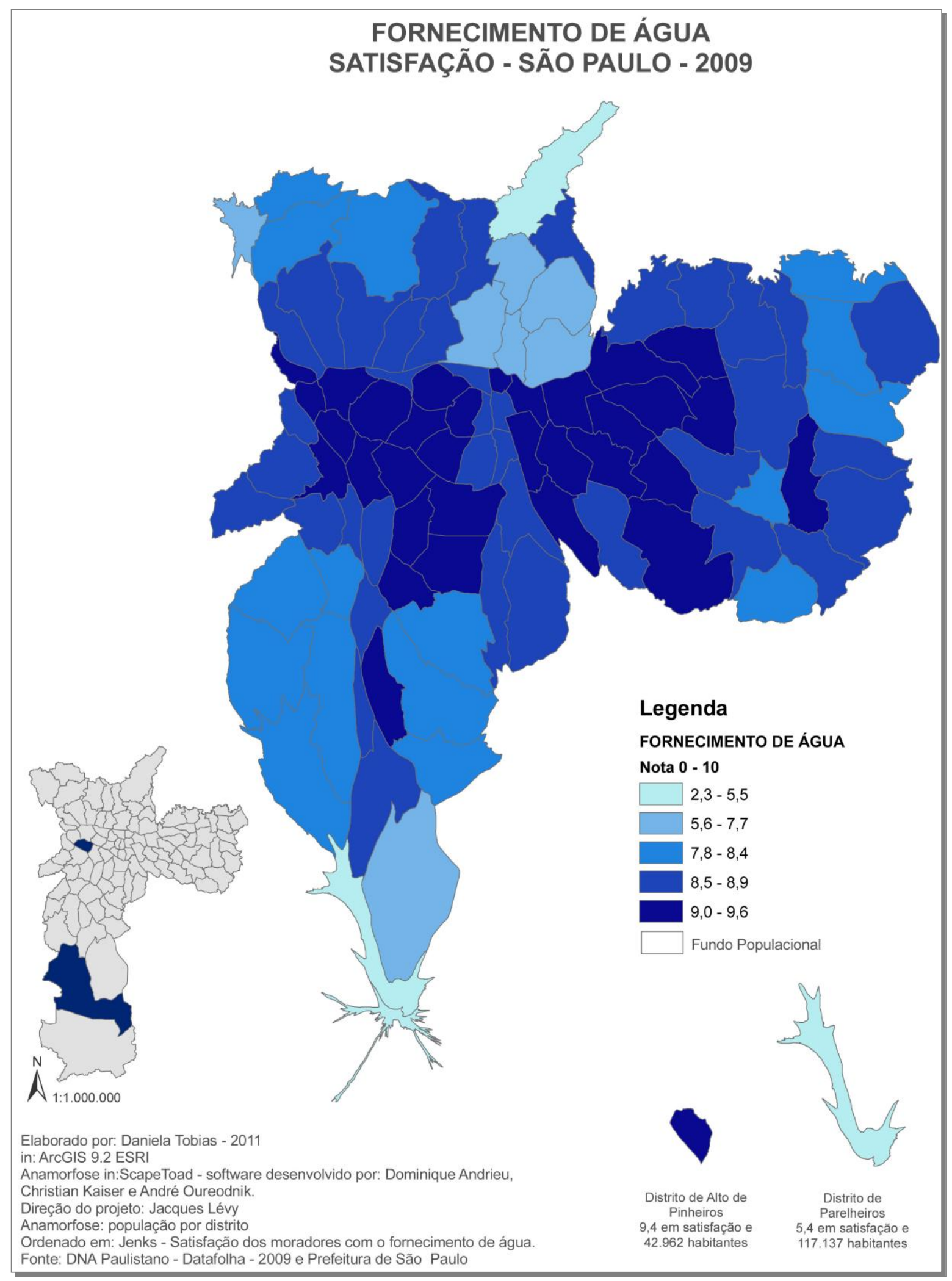

Mapa 23 - Fornecimento de água - satisfação - São Paulo 2009 


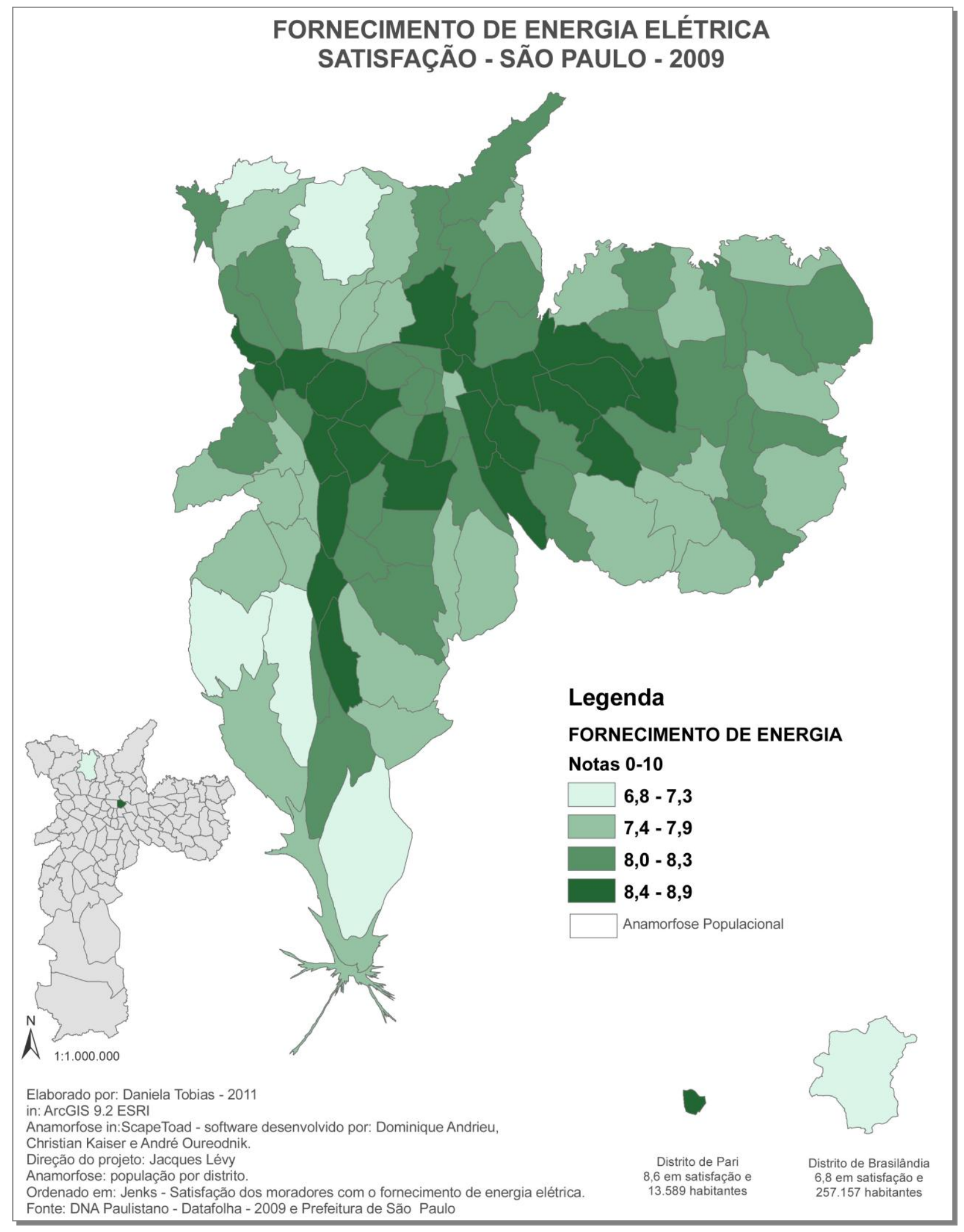

Mapa 24 - Fornecimento de energia elétrica - SATISFAÇÃO

São Paulo 2009 


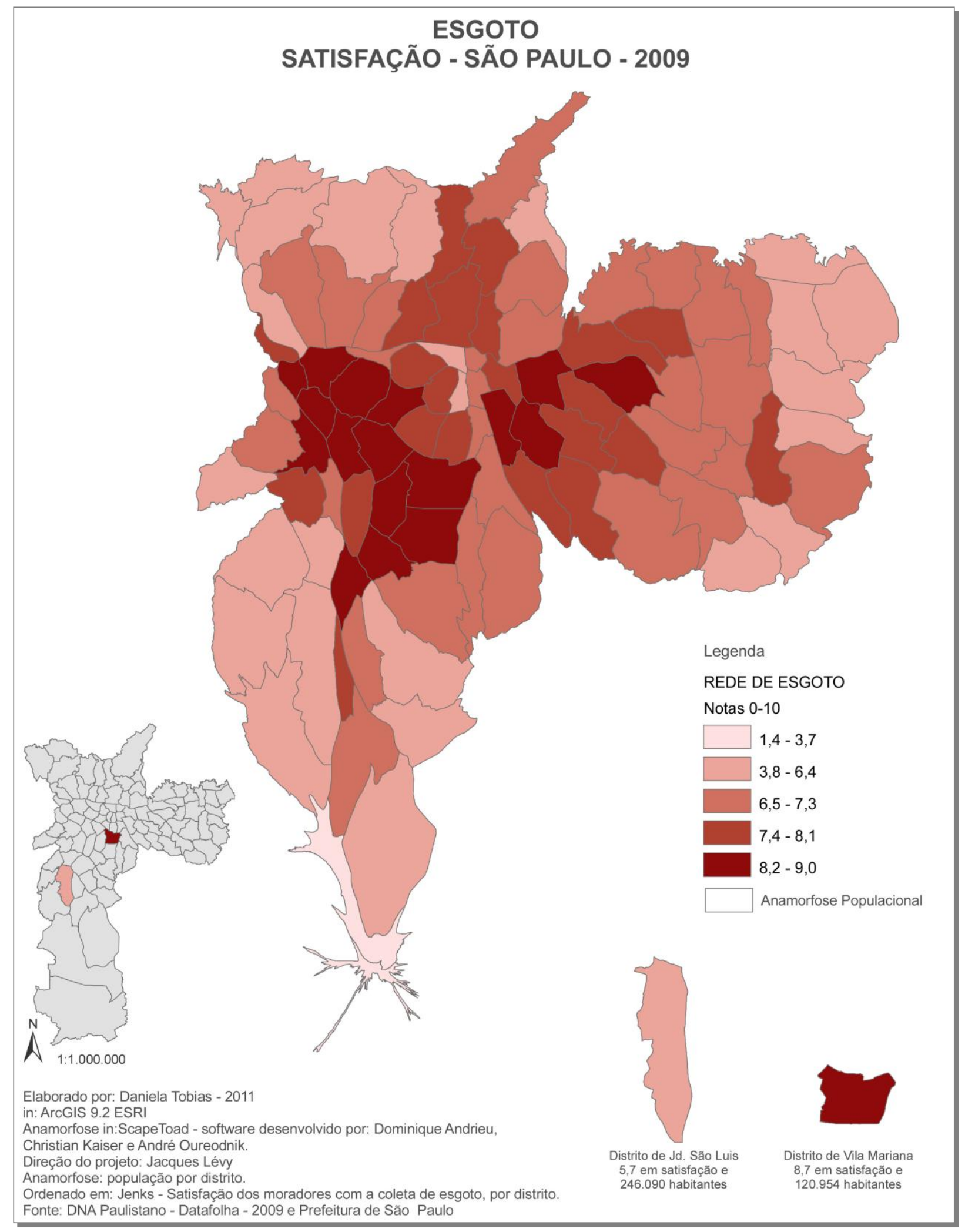

Mapa 25 - Esgoto - satisfação - São Paulo 2009 
Nos (mapas 23, 24 e 25) que tratam da oferta de infraestrutura básica para a cidade de São Paulo, notamos um contrataste evidente entre os distritos da cidade. A preocupação aumenta quando analisamos a anamorfose populacional e verificamos que, na maioria das vezes, os distritos mais populosos são também os mais despossuídos da oferta destes equipamentos. Fato que se torna inquestionável para os distritos das zonas Sul, Leste e extremo Norte.

Observamos estes índices avaliados nos (mapas 23, 24 e 25), sequencialmente: Fornecimento de Água, Fornecimento de Energia Elétrica e Esgoto, que obtiveram as maiores notas de satisfação, comparados a outros índices urbanos, 9,6-8,9-9,0. Sabemos que tais resultados são devidos ao fato de que, estes são a base essencial a qualquer processo de urbanização e também da base para inserção e manutenção de qualquer processo de produção do capital. Este último, a produção e reprodução do capital, aparentemente possui maior força de influência, já que os distritos com menor vocação para comércio e serviços apresentam baixas e até mesmo baixíssimas notas de satisfação, como é o caso de Engenheiro Marsilac e Parelheiros quanto ao fornecimento de Água e redes de Esgoto; distritos de Perus, Brasilândia, Capão Redondo, São Luis e Grajaú quanto ao fornecimento de Energia elétrica.

\footnotetext{
"A questão é complexa e importa debater de que maneira a sociedade e especificamente os urbanistas (ou planejadores urbanos) enfrentarão 0 desafio representado pela urbanização do mundo de hoje. [...] A cidade, a região metropolitana, cada vez mais se insere no contexto mundial. À medida que o capital se internacionaliza, o espaço também se internacionaliza. Atenção, contudo, à internacionalização perversa, à geopolítica do grande capital!". (SOUZA, 1988, p.9)
}

Se correlacionarmos estes três índices básicos da urbanização paulistana, evidenciados espacialmente e confrontados com a anamorfose do tamanho da população, projetaremos uma cidade, que apesar de estar inserida no contexto mundial de internacionalização do capital, também está muito aquém das possibilidades de desenvolvimento urbano esperado e desejado pela população. 


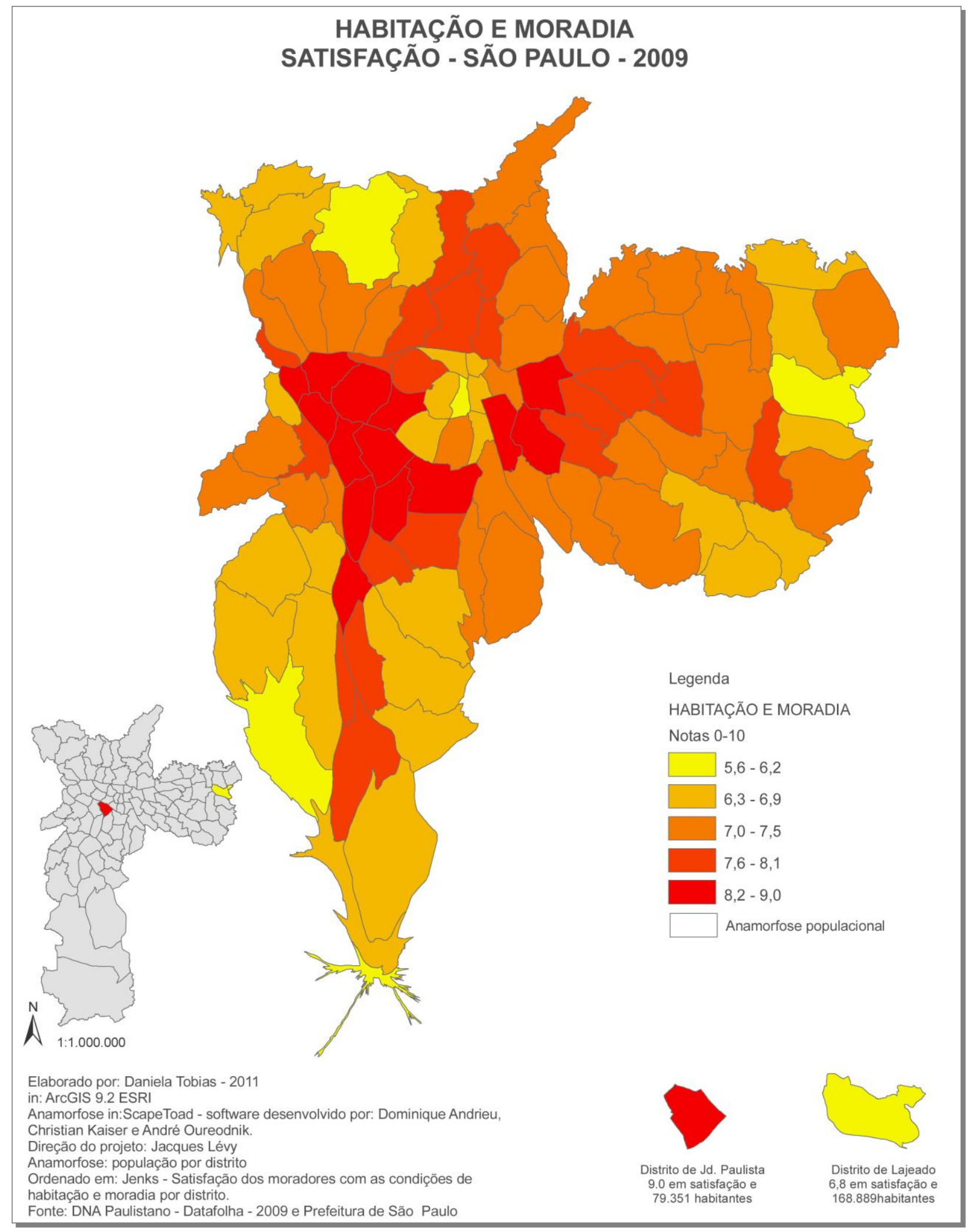

Mapa 26 - Habitação e moradia - satisfação - São Paulo 2009 


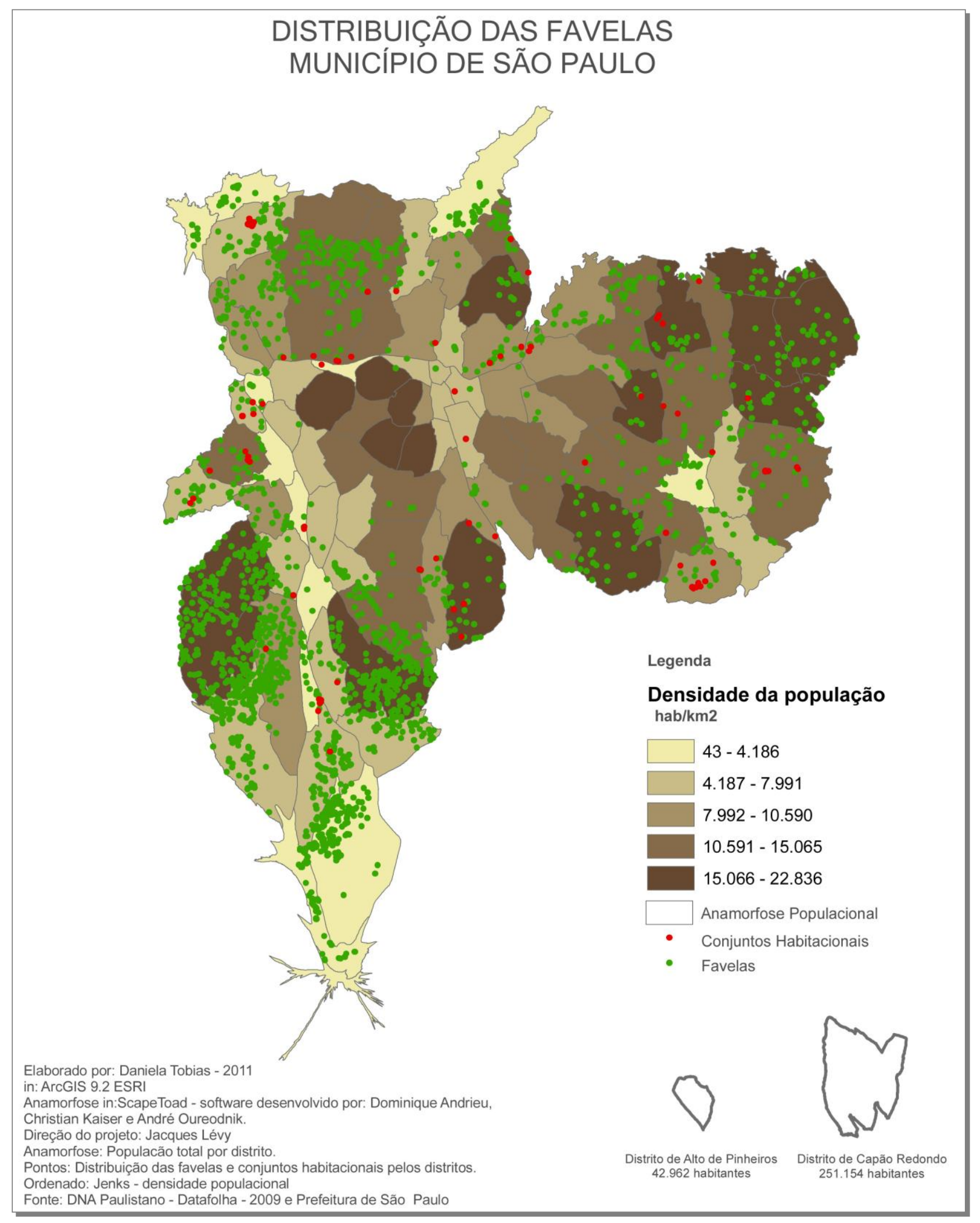

Mapa 27 - Distribuição das favelas - São Paulo 2009 
Dentro da questão da Moradia e Habitação verificamos o processo de favelização, manifestado no entorno da área mais favorecida de recursos urbanos (mapa 27) nas periferias da cidade, nas áreas menos favorecidas de equipamentos culturais e sociais. O que é confrontado com os novos afastamentos residenciais, os condomínios fechados, superprotegidos e homogeneizantes desejados pelas classes economicamente favorecidas e que são ricos em estruturas urbanas. As favelas localizadas na região central, que não são tão numerosas, se manifestam nos distritos que apresentam menores quantidades populacionais, em uma área de expulsão e não de atração populacional e muito menos de diversidade dessa população.

A construção dos conjuntos habitacionais em consonância com as ações da Prefeitura de São Paulo para uma socialização de inserção das comunidades moradoras das favelas busca dar condições de "melhoria" de vida a essa população carente. Em se tratando de uma ação que atua de forma a manter a localização e a clientela destas ações, ela se torna pouco diversificada e muito impositiva, já que essa transição, da favela para o conjunto habitacional acontece de maneira pouco ou nada participativa.

Milton Santos apresenta uma crítica à forma como se processa esse raciocínio imobiliário, para os pobres, e as construções apresentadas a essas classes populares.

\begin{abstract}
"Quando, diante da situação explosiva nas cidades e em face da proximidade de eleições, foi decidido construir casas para os mais pobres, foi para lhes dar habitações que já nasciam subnormais, neste caso sem aspas. A normalidade estabelecida para os pobres por definição oficial, aconselhada e defendida por pseudo-intelectuais, passou a autorizar a construção de habitações tão pequenas que conduzem a toda espécie de confinamentos e promiscuidades". (SANTOS, 2007, p.62)
\end{abstract}

Embora apenas alguns distritos: Brasilândia, Lajeado, Jd. Ângela e Sé tenham manifestado grande insatisfação com as condições de Moradia e Habitação (mapa 26), sentimentos coletivos de medo, insatisfação e insegurança real e midiática rondam as formas de identificação dos cidadãos paulistanos com os espaços da moradia. 


\begin{abstract}
"A localização das pessoas no território é, na maioria das vezes, produto de uma combinação entre forças de mercado e decisões de governo. Como o resultado é independente da vontade dos indivíduos atingidos, frequentemente se fala de migrações forçadas pelas circunstâncias a que se alaúde acima. Isso equivale também a falar de localizações forçadas. Muitas dessas contribuem para aumentar a pobreza e não para a suprimir ou atenuar". (SANTOS, 2007, p. 141)
\end{abstract}

Torna-se muitas vezes, um planejamento urbanístico, ligado a alterações das feições urbanas, do que, uma oferta de qualidade de vida e melhoria das condições de vida na cidade. Não questionamos a importância de uma ação e sim a maneira e o lugar oferecido, na maioria das vezes as populações moradoras de favelas não querem se afastar deste lugar, onde já construíram todo o seu capital social, escolas, postos de saúde, emprego e formas de transporte.

Isso sem entrarmos no mérito da redistribuição de renda, para que através de seus próprios recursos a sociedade paulistana decida, dentro de um planejamento urbano de loteamento, o lugar onde lhe interessa e convém morar.

Essas "localizações forçadas", muitas vezes empurram ou mantém a população em espaços indesejados como é o caso da população residente em áreas de constantes enchentes na cidade de São Paulo.

A insatisfação por enchentes (mapa 28) nos mostra que este fenômeno, apesar de muito preocupante e emergente, atua de forma pontual, recebendo notas bastante baixas, apenas em alguns distritos como: Cambuci, Sé, Tremembé, Ipiranga, Jd. Helena, Bom Retiro, Pari, Brás e se aproximando muito destes estão, Brasilândia, Jd. São Luis e Vila Curuça. Sendo assim no mapa em geral, ele não aparece como um elemento de destaque na cidade.

A questão das enchentes aparece sempre relacionada à questão da limpeza da cidade. Atribui-se à própria população a responsabilidade pela ocorrência do problema das enchentes, com os entupimentos dos bueiros. Até mesmo as questões topográficas ficam alheias. É o cidadão paulistano que não consegue resolver este problema. Neste momento entram os discursos de educação ambiental, apresentados como caminhos de solução. Ou, como 
apresenta Paulo Cesar da Costa Gomes (2002, p.190) trata-se de uma questão de significação social.

"Ora, no Brasil costuma-se relacionar o lixeiro, dentro da escala de hierarquia social, como o elemento situado na base dessa pirâmide. Jogar lixo no chão significa, portanto, a demonstração de um certo privilégio social, por menor que ele seja. Em outros termos, as pessoas não sujam o espaço público simplesmente por falta de informação, pois ninguém tem o mesmo comportamento dentro de suas próprias casas. Suja-se o chão como uma demonstração de prestígio social, pois isso quer dizer que alguém, menos importante socialmente, deverá recolher a sujeira produzida" (GOMES, 2002, p.190)

Para discordar dessa visão relacionada entre a sujeira da cidade com 0 status pessoal, verificamos nos (mapas 29 e 30), respectivamente Coleta de Lixo e Limpeza Pública (ruas e avenidas), que a sujeira aparece como elemento de insatisfação, onde já existe grande ausência de medidas públicas. Ligar à questão da sujeira da cidade a necessidade de ascensão social seria minimizar a importância de ações públicas, de estrutura básica em áreas onde este fenômeno tem maior ocorrência. Seria, contudo, uma ação de imobilidade por parte dos gestores da cidade que estariam livres de um planejamento real para solucionar ou melhorar a questão da limpeza, já que esta estaria relacionada ou a falta de educação ambiental da população (o que ainda assim seria responsabilidade do Estado), ou a uma questão ideológica de postura social coletiva.

Quanto a Coleta de Lixo, esta apresentou um elevado índice de satisfação pela população, apresentando os distritos de Bela Vista, Sé, República e Brás, nas regiões centrais como os menos satisfeitos, fato que está relacionado ao intenso uso destes espaços pela população da cidade de um modo geral. Todavia é notório a ineficácia da presença do Estado nestas áreas, que ficam fadadas ao fatalismo dessa condição. Estas áreas que já sofrem com a questão da homogeneização de ocupação, com o esvaziamento residencial e com o acesso da violência, ficam também com a insatisfação não somente de seus ocupantes como também de seus frequentadores, cada vez menos frequentes.

Já o distrito de Brasilândia que aparece como insatisfeito, tanto com a coleta de lixo, quanto com a limpeza das ruas, também tem recebido notas 
bastante baixas em todos os outros equipamentos urbanos. O distrito de Morumbi também apresentou menores notas quanto a Coleta de lixo.

Quanto a Limpeza Pública de ruas e avenidas os distritos do Extremo Sul, Engenheiro Marsilac, Parelheiros, Grajaú e bem perto destes, Capão Redondo apresentam maiores índices de insatisfação, juntamente com os distritos centrais, já mencionados. Já entre os mais satisfeitos estão, Campo Belo, Perdizes e Alto de Pinheiros, distritos que também vêm apresentando os melhores índices nos demais fenômenos analisados.

Não é somente a questão da limpeza da cidade que merece atenção, mas esse abandono do poder público libera espaço para as diversas práticas transgressoras da cidade ao expulsar dessas áreas uma população diversificada, já que ali há uma oferta de atividades diversificadas e também uma oferta de bem estar, formando um cenário que tem sido ocupado por práticas de violência.

No (mapa 31 - Segurança Pública) as notas variaram apenas de 3,0 a 6,6 , em uma escala que vai de zero a dez, e sem nenhuma surpresa, as regiões que apresentaram viverem em constante sensação de insegurança, são as regiões do Sul, Centro, Leste, Extremo Leste e Extremo Norte.

A temática da Segurança que aparece bastante frequente para se relacionar a qualquer outro índice da cidade não apresenta surpresas, nem quanto à insatisfação ou mesmo quanto à satisfação dos moradores da cidade.

No mesmo eixo de análise segue o (mapa 32 - Iluminação Pública), que para alguns distritos reforça a questão do abandono público e interliga a questão da falta de iluminação com a violência e com a situação de baixa renda. 


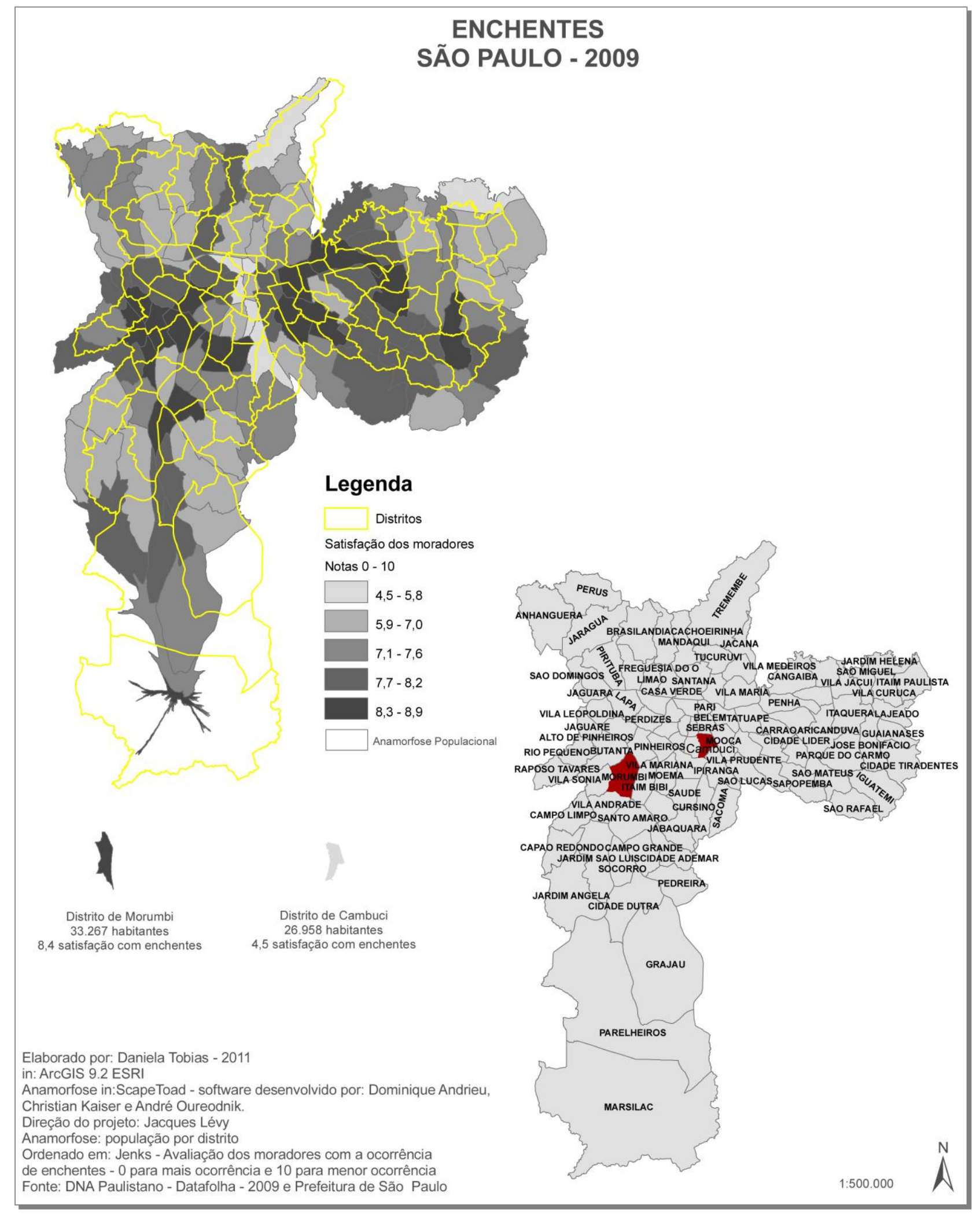

Mapa 28 - Enchentes - São Paulo 2009 


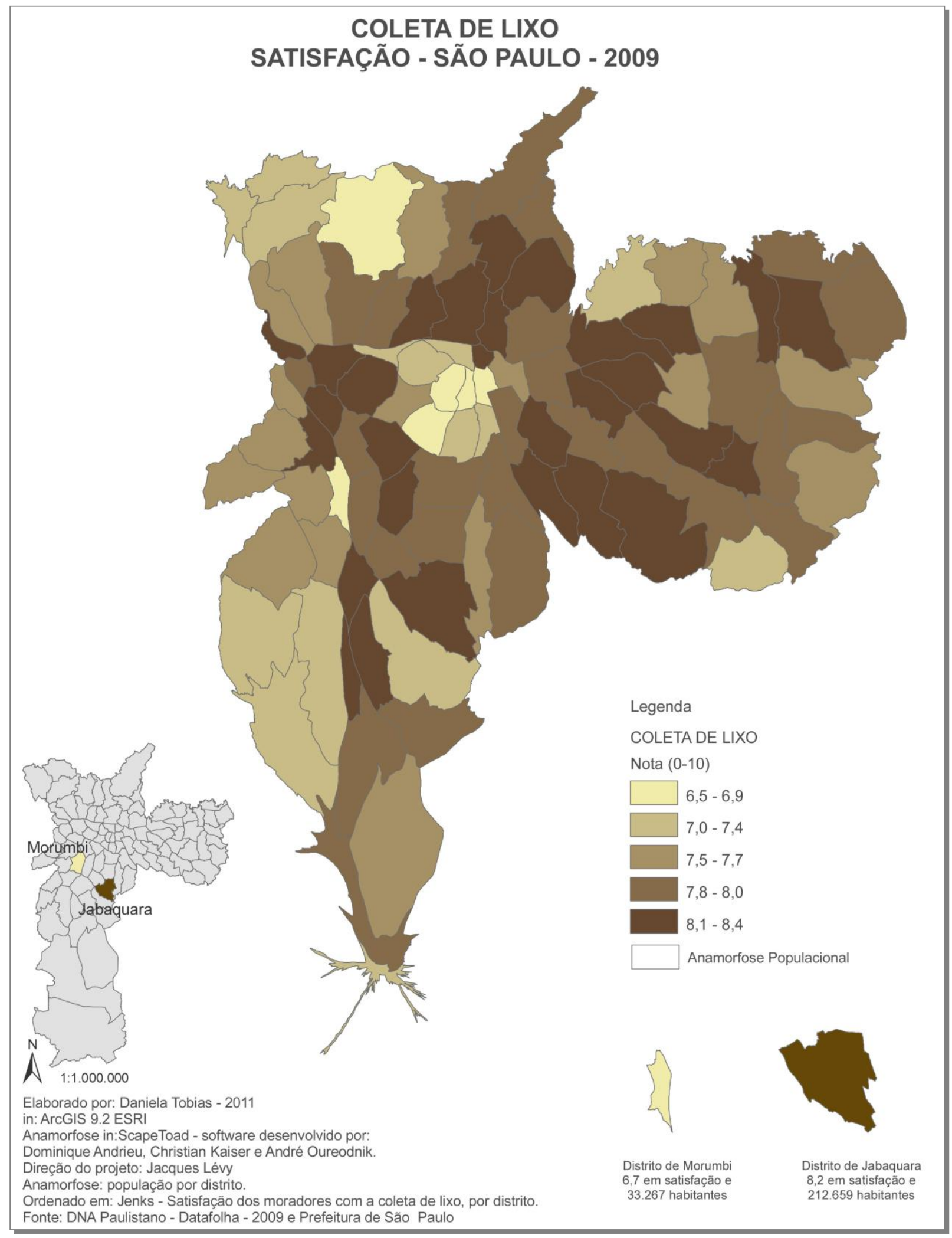

Mapa 29 - Coleta de lixo - satisfação - São Paulo 2009 


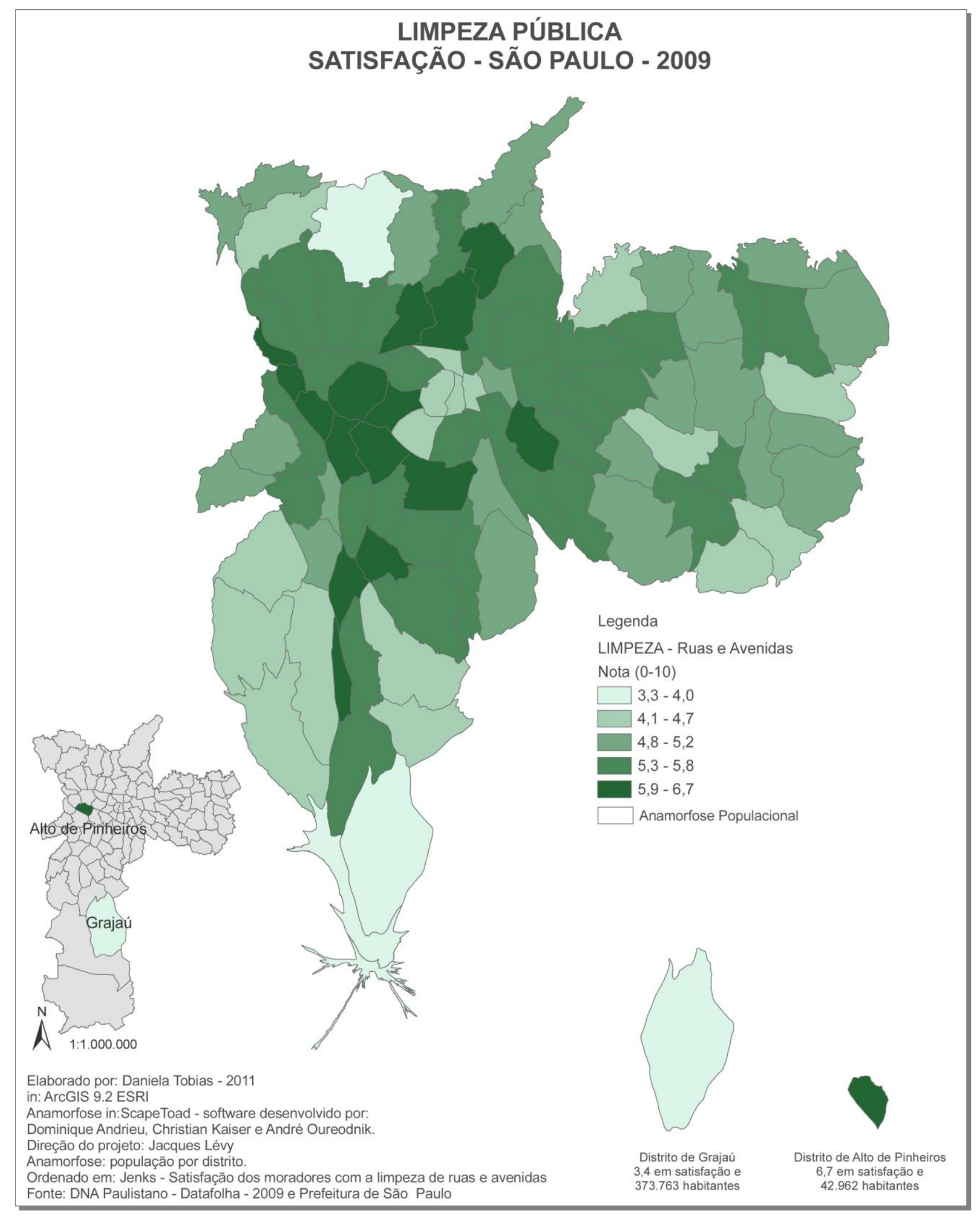

Mapa 30 - Limpeza pública - satisfação - São Paulo 2009 


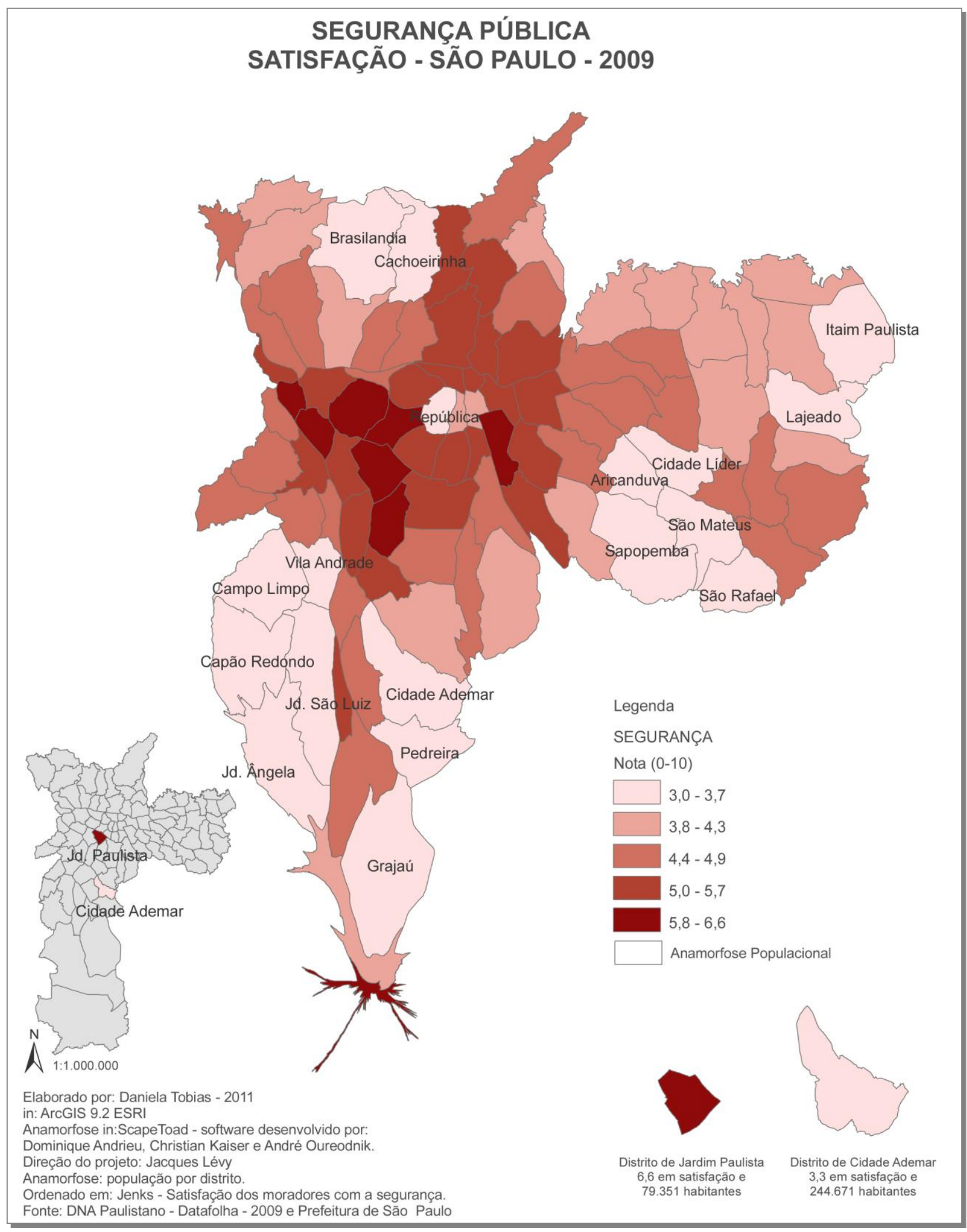

Mapa 31 - Segurança pública - satisfação - São Paulo 2009 


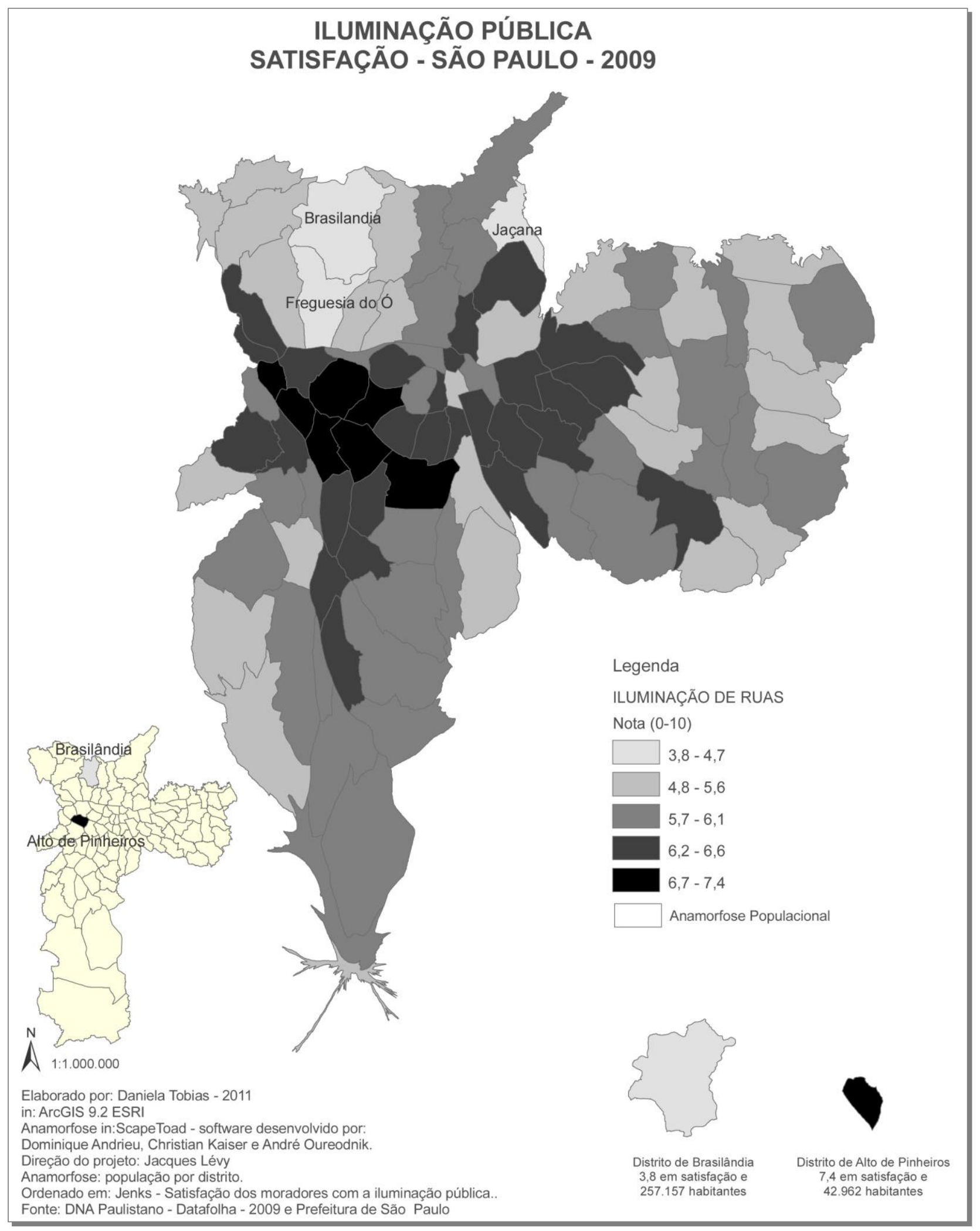

Mapa 32 - Iluminação pública - satisfação - São Paulo 2009 
Outro elemento pontual para uma análise da cidade de São Paulo tem sido o Silêncio das ruas (mapa 33) que apresenta uma espacialização deste fenômeno diferente da maioria observada até o momento, rompendo com a visão de centro/periferia. Sabemos que esta visão de centro/periferia, não cabe de forma tão harmônica na cidade de São Paulo, porém ela é muito mais evidente quanto à questão do silêncio das ruas.

A satisfação com o Silêncio das Ruas presenta as melhores notas apenas nos distritos da Zona Oeste: Butantã e Alto de Pinheiros e na Zona Leste: Mooca e Água Rasa. Contudo o que fica evidente neste mapa é a insatisfação com o silêncio das ruas apresentado pelas áreas de maior grandeza populacional, que receberam notas bastante inferiores, mesmo comparados a regiões de grande fluxo de pessoas.

O (mapa 34 - Distribuição das Praças Públicas e Canteiros Centrais em São Paulo) aparece para buscar evidenciar a importância dos espaços públicos e a importância dos usos destes espaços na cidade. Vemos essa mesma intencionalidade apresentada no Plano Diretor e Estratégico da cidade de São Paulo.

\section{Subseção III - Dos Espaços Públicos \\ Art. 115 - Os espaços Públicos constituem elemento integrador na medida em que são ponto de encontro para os contatos sociais e a comunicação visual e palco para as manifestações coletivas e o exercício da cidadania.}

Parágrafo único: $A$ ampliação dos espaços públicos, sua escala, definição, conformação $e$ tratamento paisagístico deverão ser adequados às funções básicas previstas para seu uso.

\section{Anexo p.82:}

A ampliação dos espaços públicos em toda a cidade, com qualidade e beleza, é um dos fatores de integração na medida em que estimula o encontro entre as pessoas e a manifestação dos cidadãos. (Plano Diretor e Estratégico, São Paulo, 2000).

É certo, que houve um momento na história da cidade, em que as Praças Públicas eram pensadas de forma a proporcionar um ambiente de integração social, onde existia a busca por uma harmonia entre a existência desse espaço e a sua funcionalidade pública. Essa forma de pensar a cidade foi sendo substituída por uma esfera produtiva do espaço que não leva em 
consideração a sua questão funcional social e quando muito a sua função urbanística de embelezamento da cidade.

Se observarmos a localização das estações do Metrô com as Praças Públicas, veremos que maior parte das vezes as estações e os seus acessos mais centralizados estão, diretamente, ocupando os espaços das praças e inclusive algumas até mesmo recebem o nome das mesmas; por exemplo: as praças e estações, Sé, República, Santa Cecília, Marechal Deodoro, Júlio Prestes elas se utilizam dos espaços das praças para ali estabelecerem as estações. Há nessa construção um choque de interesses, onde as Praças são espaços de responsabilidade da Prefeitura e as estações são do Estado, que por compra ou concessão de uso se apropriam desses espaços.

Este fato gera discussões, pois a implantação das estações em determinadas praças muitas vezes são motivo de uma nova normatização desse espaço como é o caso da estação Anhangabaú que modificou e praticamente isolou o Largo da Memória. Há inclusive uma faixa branca no chão que delimita até onde vai o espaço do Estado dentro do espaço da Prefeitura na praça. Mesmo o acesso existente na estação para a Praça foi fechado, alegando o Metrô, a necessidade de separação com o público indesejado da Praça.

Jane Jacobs (2000, p.510) explica que "os espaços físicos das praças e parques estão diretamente ligados ao uso que se dá a esses espaços, sem essas relações esses espaços não servem para nada e podem até mesmo deixar de existir".

Muitos dos problemas enfrentados na cidade em relação ao uso dos espaços públicos estão relacionados à gestão municipal, mas sabemos que em uma cidade das dimensões de São Paulo, existem outros fatores que contribuem para esse aparente desinteresse, mesmo relacionados a fatores mundiais de forma e ritmos de vida.

"O valor do indivíduo depende, em larga escala, do lugar onde está [...] Em nosso país, o acesso aos bens e serviços essenciais, públicos e até mesmo privados é tão diferencial e contrastante, que uma grande maioria de brasileiros, no campo e na cidade, acaba por ser privada destes bens e serviços. Às vezes tais bens e serviços simplesmente não existem na área, às vezes não podem ser alcançados por questão de tempo ou de dinheiro" (SANTOS, 2007, p. 139) 


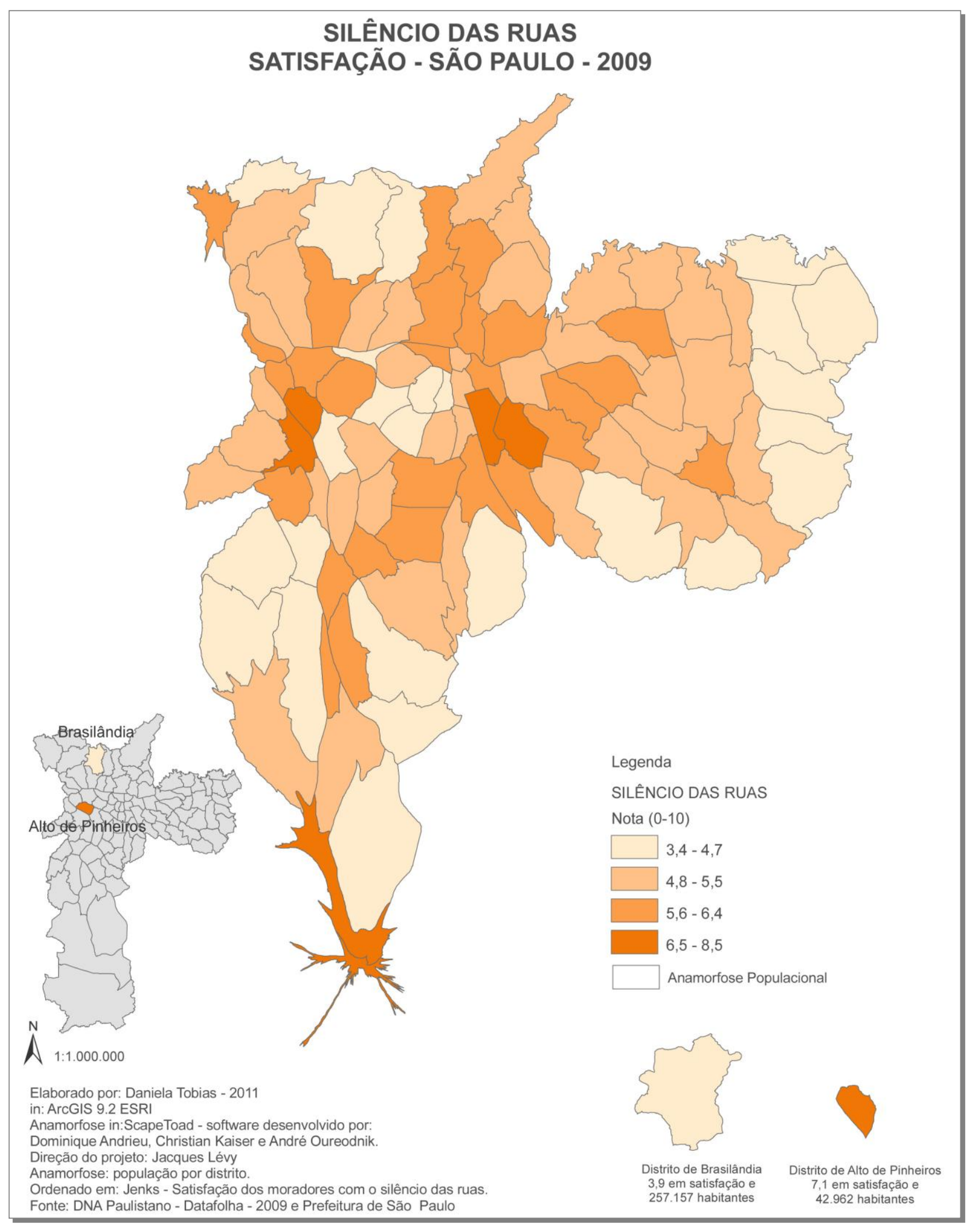

Mapa 33 - Silêncio das ruas - satisfação - São Paulo 2009 


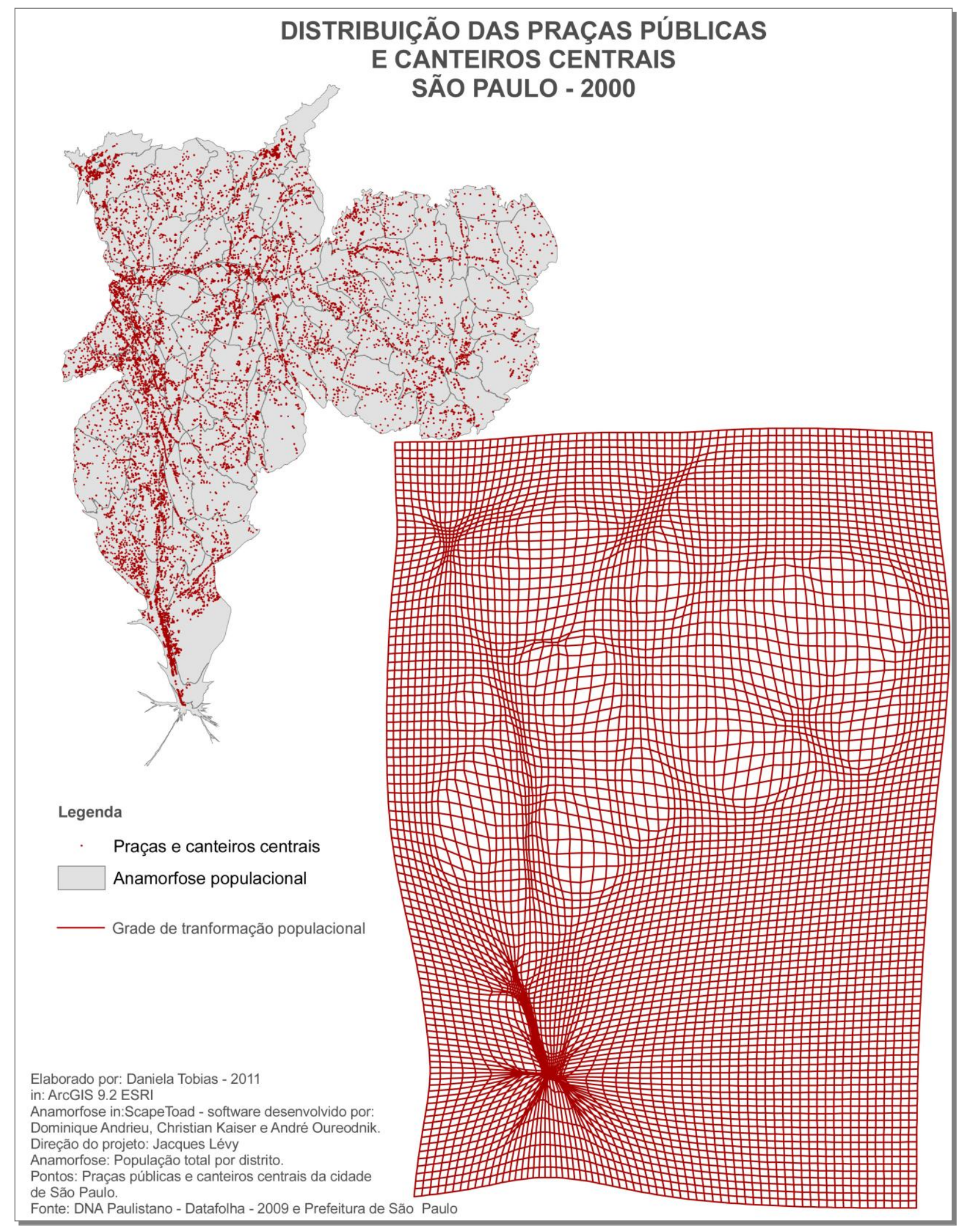

Mapa 34 - Distribuição das praças públicas e canteiros centrais

São Paulo 2000 
Para finalizar apresentamos o (mapa 35 - Satisfação dos Moradores), como uma síntese das avaliações apresentadas em todos os mapas e como uma síntese de ações e equipamentos urbanos e sociais existentes na cidade de São Paulo.

Mesmo aqui vemos o desenho evidente de uma área "core" uma área de "destaque" evidenciada na cidade, que são os distritos que receberam as melhores notas de satisfação de seus moradores. São distritos que repetidas vezes foram os possuidores das melhores condições urbanas e realização do ser social urbano, tanto com relação à questão da oferta de acessibilidade e mobilidade quanto ao bem-estar, relacionando os indicadores de cada localização.

As disparidades regionais apresentadas nesta cidade corroboram a importância de um estudo urbano de escala local, onde vemos a presença da dimensão mundo, da oferta de acesso à globalização, apenas em alguns pontos da cidade, e uma carência e um atraso nas ofertas de possibilidades em outros. 


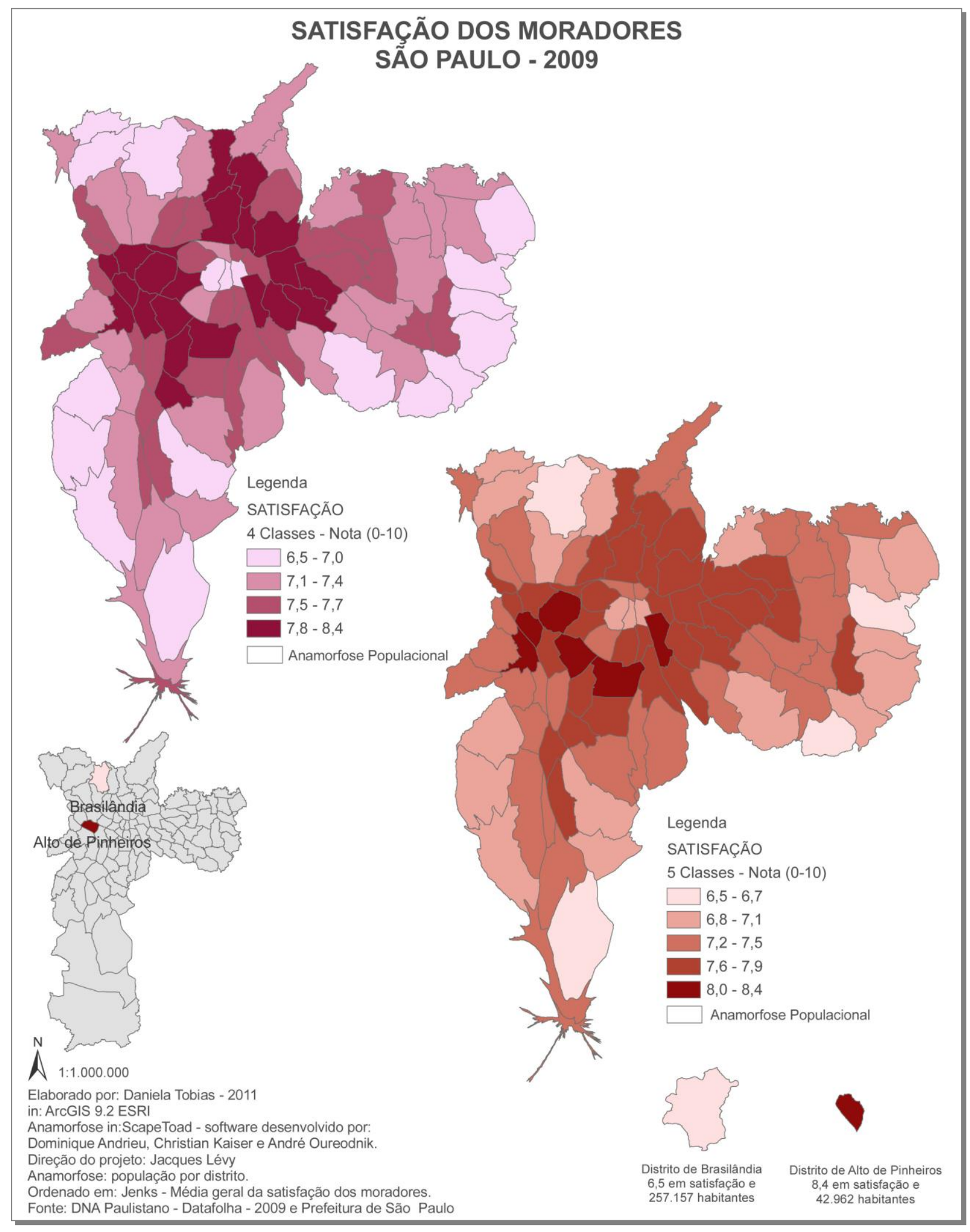

Mapa 35 - Satisfação dos moradores São Paulo 2009 - Pesquisa DNA Paulistano 


\section{CONSIDERAÇÕES FINAIS}

Essa dissertação investe numa Geografia do município de São Paulo, numa Geografia da escala local (a escala do lugar). Isso não quer dizer que as explicações sobre essa escala encontrem-se apenas nelas. É preciso considerar também outras abordagens escalares, chegando inclusive a escala global.

Insistimos na escala do lugar, para buscar aproximar os fenômenos cotidianos de uma representação pouco praticada, mas que pudesse revelar certas especificidades em espacialidades tão próximas, como são os distritos dentro de um mesmo município.

Este mapeamento que fez uso da anamorfose teve o objetivo de buscar alternativas de construção cartográfica, capazes de representar o urbano, de revelar os elementos constituidores da cidade e de permitir a aplicação de métricas diversas, e não apenas a euclidiana, que está naturalizada nos mapas. Assim temos uma cidade apresentada pela cartografia, uma cidade que não está aprisionada numa única métrica espacial, o que possibilitou isolar alguns fenômenos de interesse e gerar visualizações incomuns da cidade.

Ao buscar o conhecimento da realidade espacial, analisando a acessibilidade e a oferta de mobilidade do município de São Paulo, apresentamos uma cidade que flui de forma a criar mobilidades diversas. Mas que também, cria isolamentos que se dão pela falta de opção e principalmente pela falta de inserção de recursos públicos, sejam eles reais ou virtuais capazes de garantir o acesso à cidade e aos seus recursos emancipadores, próprios de uma vida urbana plena.

Os contrastes no município são grandes. É notável a existência de uma região da cidade que se beneficia de vários equipamentos urbanos muito bem avaliados pelos seus moradores, enquanto que em outras regiões a precariedade domina. Assim como também é visível a reprodução desta mesma forma de produzir espaços, de produzir contrastes, tanto pelo poder público, quanto pela iniciativa privada. 
A forma de gestão do município de São Paulo faz com que seja reforçada a máxima de que nela existia: mais, do mesmo, no mesmo lugar. Mais estruturas de mobilidade ou de permanência, mais da mesma forma de reprodução onde estas estruturas já estão estabelecidas, sem apresentar grandes mudanças ou alternativas criativas em espaços mais amplos do município.

No (mapa 14 - que representa os - Estabelecimentos Comerciais e de Serviços) nota-se que esses funcionam como elementos atrativos para diversos outros recursos urbanos, sejam eles os transportes, as comunicações e, inclusive para mais estabelecimentos semelhantes, como shoppings e cinemas.

Ao mesmo tempo em que temos no centro velho da cidade parte desta estrutura comercial e de serviços representada no mapa 14, temos também um esvaziamento deste espaço, nos distritos de Sé, República, Brás e também Bom Retiro e Bela Vista. Percebemos que este esvaziamento se explica pela insatisfação quanto a Limpeza Pública - (mapa 30), quanto a Coleta de Lixo (mapa 29), quanto a Segurança Pública - (mapa 31), quanto ao Silêncio das Ruas - (mapa 33), quanto a Moradia - (mapa 26) e quanto ao Trânsito - (mapa 12).

É na região central, onde se encontra a maior quantidade de salas de Teatro, Shows e Concertos - (mapa 17) verificam-se índices contraditórios de repulsão gerada pelo movimento e também de atração em razão de sua oferta cultural. Isso faz com que haja nestes espaços "várias cidades", 1. uma que funciona nos horários comerciais, com grande fluxo de trabalhadores das áreas de comércio e serviços e mesmo em instituições públicas que para lá se mudaram; 2. outra nos fins de semana (e à noite) que atende uma clientela interessada nas práticas culturais; 3. e uma terceira que é aquela formada pelos moradores que demonstram sua insatisfação com o abandono público e privado dos espaços da região.

O levantamento de indicadores espaciais voltados ao cotidiano compartilha da visão que o espaço é um componente social e necessita ser representado dessa forma para oferecer rumos de compreensão, para contribuir nas decisões sobre às políticas que incidem nele. A apreensão feita 
desse modo e os conhecimentos gerados fazem parte de uma proposta de competências necessárias às práticas sociais.

É necessário atribuirmos responsabilidades e cobrar ações do poder público. Porém verifica-se que em uma cidade que se organiza de forma a atender as exigências do mercado, o poder público deve apresentar soluções aos problemas gerados, não somente como mitigadores de impactos espaciais, mas principalmente com a criação de novas espacialidades, que permitam a cidade equalizar seus instrumentos de urbanidade.

O planejamento e a gestão participativa são desafios para uma cidade com as dimensões de São Paulo. Estes têm ocorrido em fragmentos (subprefeituras e distritos) com o chamamento de seus moradores para prática política no município e a proposta de planejamento, como ocorre com o Plano Diretor e Estratégico da cidade e mais comumente com as administrações de bairros.

Porém, pelas características de vida da população o tempo torna-se um artigo de luxo. Citadinos que gastam boa parte de sua vida no trânsito e nas atividades básicas (trabalho e estudo) não encontram meios para uma participação direta na gestão e no planejamento da cidade. Todavia isso não ocorre por falta de vontade política, mas sim pela falta de acesso a informação, pela falta de meios de comunicação que alcance os habitantes da cidade. Estabelecer contato com os moradores da cidade e mesmo com os moradores de um bairro pode alcançar maior eficiência se usados os meios de comunicação ofertados hoje ao grande público, algo que não é bem feito. Não somente as ouvidorias, que estão cada vez mais cheia de problemas e queixas, mas também um canal de participação, de informação que permita a oferta de ideias para as gestões locais e mesmo municipal.

Para o citadino poder participar e decidir sobre as formas de gestão dos seus espaços de vida, faz com que a relação com esse espaço se torne mais próxima, e esta identidade espacial contribua no desenvolvimento de uma cidadania plena, que significa cidadãos mais comprometidos e desejosos de vivenciar sua cidade. Praticar a cidade, usar seus espaços e oferecer ideias de melhorias nos torna menos moradores da cidade e mais cidadãos paulistanos. 


\section{REFERÊNCIAS BIBLIOGRÁFICAS}

BRASIL. Ministério da Educação e do Desporto. Parâmetros Curriculares Nacionais - Matemática 5a a 8aㅡ série. Brasília: SEF, 1998.

BRASIL. Ministério da Educação e do Desporto. Parâmetros Curriculares Nacionais - Geografia 5a a 8ª série. Brasília: SEF, 1998.

CALDEIRA, Teresa P. R. Cidade de Muros. São Paulo: Editora 34 / Edusp, 2000.

CAUVIN, Colette. Transformações cartográficas espaciais e anamorfoses. In: DIAS, Maria Helena (Coord.) Os mapas em Portugal: da tradição aos novos rumos da cartografia. Lisboa: Cosmos, 1995. p: 267-310.

CARLOS, Ana Fani A. Espaço-Tempo na Metrópole: a fragmentação da vida cotidiana. São Paulo: Contexto, 2001.

CRAMPTON, Jeremy W. e KRYGIER, John. Cartografias sociais e território. In: ACSELRAD, Henri. (org.), Rio de Janeiro: UFRJ/IPPUR, 2008. p: 85-111.

DUTENKEFER, Eduardo. Representações do espaço geográfico: mapas dasimétricos, anamorfoses e modelização gráfica. São Paulo: FFLCH/USP, Dissertação (Mestrado em Geografia), Programa de Pós Graduação em Geografia Humana, Universidade de São Paulo, 2010.

ESCHER, Mauritus Cornelis, Biografia, acesso em: 21/06/2010, disponível em: $<$ http://www. educ.fc.ul.pt/docentes/opombo/seminario/escher/varanda.html>

FONSECA, Fernanda Padovesi. A inflexibilidade do espaço cartográfico, uma questão para a Geografia: análise das discussões sobre o papel da Cartografia. São Paulo: FFLCH/USP, Tese (Doutorado em Geografia), Programa de Pós Graduação em Geografia Humana, Universidade de São Paulo, 2004.

GENTILE, Rogério; MARRA, Fábio. DNA Paulistano: a mais abrangente pesquisa de opinião sobre a relação dos paulistanos com sua cidade. São Paulo: Publifolha, 2009.

GOMES, Paulo Cesar da Costa. A condição urbana: ensaios de geopolítica da cidade. Rio de Janeiro: Bertrand, 2002.

HARLEY, J. Brian. "Mapas, saber e poder ", Confins [Online], 5 | 2009, posto online em 24/abril/2009, Consultado em 18/junho/2011. URL: http://confins.revues.org/5724. (Traduzido por Mônica Balestrin Nunes).

HARVEY, David. A Condição Pós-moderna. São Paulo: Loyola, 1992.

HASSAN, Sara E. Pintores e Poetas no roteiro da pulsão escópica: anotações preliminares. Acesso em: 01/10/2010, disponível em: $<$ http://www.eca.usp.br/caligrama/n 10/02 hassan.pdf>

INSTITUTO BRASILEIRO DE GEOGRAFIA E ESTATÍSTICA - IBGE. Censo

Demográfico 2000. Rio de Janeiro: IBGE, 2003. 
JACOBS, Jane. Morte e Vida de Grandes Cidades. São Paulo: Martins Fontes, 2000.

LÉVY, Jacques. Anamorphose. In: LÉVY, Jacques; LUSSAULT Michel (Org.). Dictionnaire de la Géographie et de l'espace des sociétés. Paris: Belin, 2003. p. 74. (Tradução de trabalho de Fernanda Padovesi Fonseca e Jaime Tadeu Oliva)

LÉVY, Jacques ; PONCET, Patrick ; TRICOIRE, Emmanuelle. La carte, enjeu contemporain. Paris, Dossier ํo 8036, Documentation photographique, La Documentation Française, 2003b.

LÉVY, Jacques. Uma Virada Cartográfica? In: ACSELRAD, Henri (Org.). Cartografias Sociais e Território, Rio de Janeiro: Universidade Federal do Rio de Janeiro, IPPUR, 2008. p. 153-167.

LÉVY, Jacques (Dir.) L'Invention du Monde: une Géographie de la mondialisation. Paris : Sciences Po. Les Presses, 2008.

LÉVY, Jacques. Os novos espaços da mobilidade. Tradução de Rogério Haesbaert e Sylvain Souchaud. Título original: Les Nouveaux Espaces de la Mobilité, in: BONNET, M.; DESJEUX, D. Les Territoires de La Mobilité, Paris: Presses Universitaires de France, 2000.

MACHADO, Arlindo. Pré-cinemas \& pós-cinemas. Campinas, SP: Papirus, 2002.

MARTINS, José de Souza. Depoimento. Espaço \& Debates, Revista de Estudos Regionais e Urbanos, Ano XVII, Número 42, "Periferia revisitada", Núcleo de Estudos Regionais e Urbanos, São Paulo, 2001. p. 75-84.

MASSEY, Doreen. Um Sentido Global do Lugar. In: ARANTES, Antonio A. (Org.). O Espaço da Diferença. Campinas: Papirus, 2000. p. 176-185

METZ, Christian. Além da analogia, a imagem. In: A análise das imagens. Petrópolis RJ: Vozes, 1973.

MUMFORD, Lewis. A cidade na História. Belo Horizonte: Itatiaia, 1965.

OLIVA, Jaime Tadeu. A cidade sobre quatro rodas. O automóvel particular como elemento constitutivo e constituidor da cidade de São Paulo: o espaço geográfico como componente social. São Paulo, FFLCH/USP, Tese (Doutorado em Geografia), Programa de Pós Graduação em Geografia Humana, Universidade de São Paulo, São Paulo, 2004.

OLIVA, Jaime Tadeu. A cidade como ator social - a força da urbanidade. In :CARLOS, A ; LEMOS, A. (org.). Dilemas urbanos: novas abordagens sobre a cidade. São Paulo: Contexto, 2003.

PALEN, J. John. O Mundo Urbano. Rio de Janeiro: Forense Universitária, 1975.

PALSKY, Gilles. Compte rendu LÉVY, J., POUCET, P., TRICOIRE E. La cartographie, enjeu contemporain , Annales de Géographie, 2005, vol. 114, $n^{\circ} 645$, p. 576.

disponível em : http:/hww.persee.fr/web/revues/home/prescript/article/geo_0003-

4010_2005_num_114_645_21248_t9_0576_0000_1, acesso em: 19/06/2011 
PANIZZA, Andrea C. Cartografia em anamorfose, acesso: 14/12/2010 disponível em: <http://geocarto.org/mapAnamorf.html>

SÃO PAULO. LEI № 13.430 , de 13 de setembro de 2002. (Projeto de Lei $n^{\circ}$ 290/02, do Executivo) Plano Diretor e Estratégico de São Paulo. São Paulo: 2002.

PREFEITURA MUNICIPAL DE SÃO PAULO - Infolocal - Secretaria Municipal de Planejamento (SEMPLA), CD-ROM , 2003

ROLNIK, Raquel. O que é cidade. São Paulo: Brasiliense, 1995.

SANTOS, Milton. Metamorfose do Espaço Habitado. São Paulo: Hucitec, 1988.

SANTOS, Milton. A Urbanização Brasileira. São Paulo: Editora da Universidade de São Paulo, 2005.

SANTOS, Milton; SILVEIRA, Maria Laura. O Brasil - Território e Sociedade no Início do Séc. XXI. Rio de Janeiro: Record, 2005.

SANTOS, Milton. Por uma outra Globalização: do pensamento único à consciência universal. Rio de Janeiro: Record, 2006.

SANTOS, Milton. O Espaço do Cidadão. São Paulo: EDUSP, 2007.

SANTOS, Milton. Manual de Geografia Urbana. São Paulo: Edusp, 2008.

SEABRA, Odete C. L. Territórios do Uso: cotidiano e modo de vida, in: Cidades, Vol.1, n. 2, Presidente Prudente: GEU, 2004. p. 181-206.

SILVA, José Marcus R. 0 cubismo e a teoria da relatividade. Revista Ciência hoje - vol.44, № 264:42, outubro 2009.

SIMIELLI, Maria Elena Ramos. Cartografia no ensino fundamental e médio. In: A Geografia na sala de aula, Ana Fani Alessandri Carlos (Org.), Editora Contexto, São Paulo, 2006. p: 92-108.

SOUZA, Marcelo Lopes de; RODRIGUES, Glauco Bruce. Planejamento urbano e ativismos sociais. São Paulo: UNESP, 2004.

SOUZA, Maria Adélia de. Governo urbano. São Paulo: Nobel, 1988.

THÉRY, Hervé; MELLO, Neli A. O Brasil: Disparidades e Dinâmicas do Território. São Paulo: Editora da Universidade de São Paulo, 2005.

TOBLER, Waldo. Thirty Five Years of Computer Cartograms. Annals of the Association os American, 2004.

TUAN, Yi-Fu. Paisagens do Medo. São Paulo: UNESP, 2005.

WIRTH, Louis. O Urbanismo Como Modo de Vida. In: VELHO, Otávio G. 0 Fenômeno Urbano 